\title{
GEOMORPHIC AND SEDIMENTOLOGIC CHARACTERISTICS OF ALLUVIAL REACHES IN THE BLACK CANYON OF THE GUNNISON NATIONAL MONUMENT, COLORADO
}

Water-Resources Investigations Report 99-4082

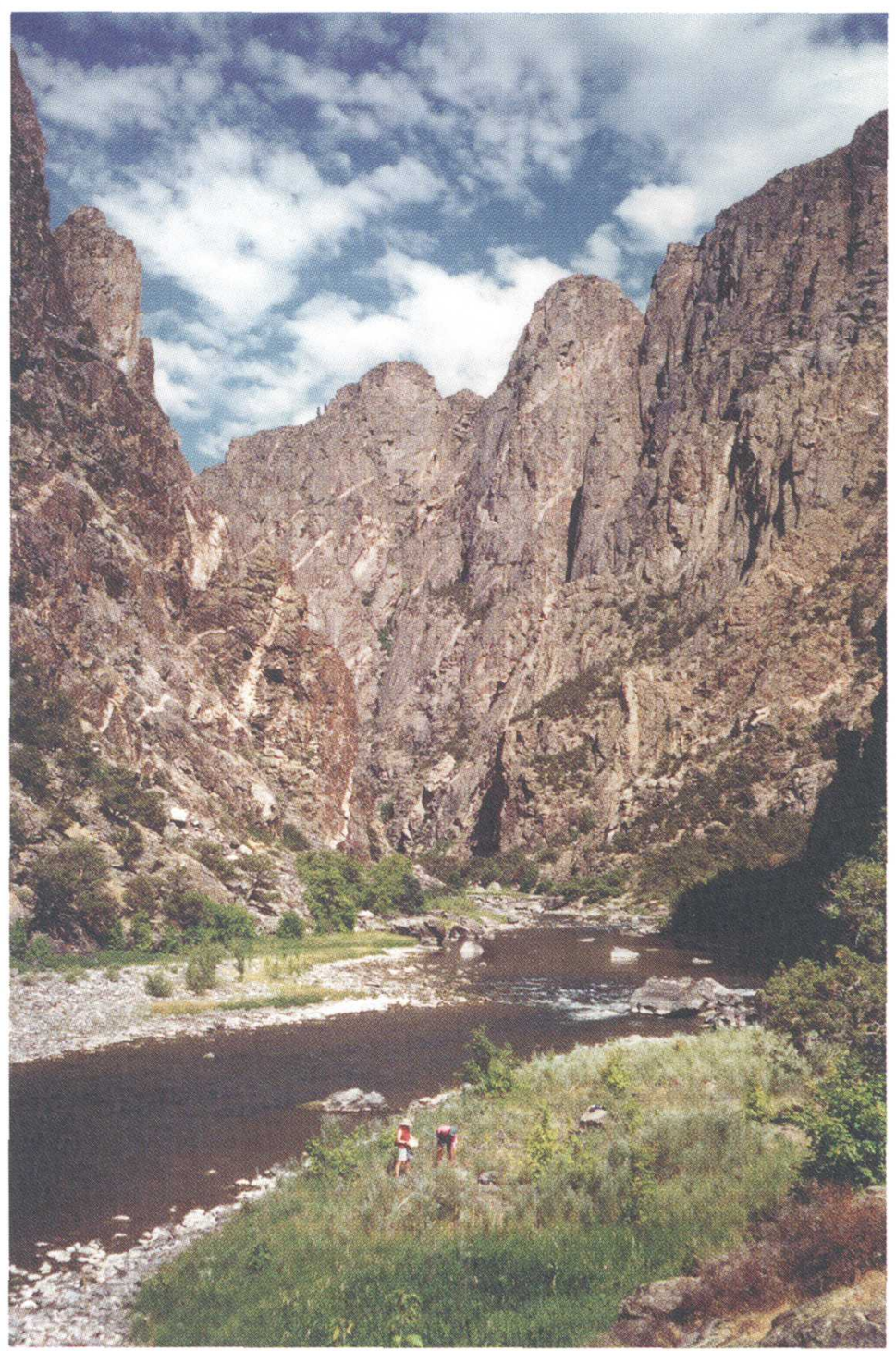

U.S. Department of the Interior

U.S. Geological Survey

Prepared in cooperation with the

NATIONAL PARK SERVICE 


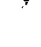




\section{Geomorphic and Sedimentologic Characteristics of Alluvial Reaches in the Black Canyon of the Gunnison National Monument, Colorado}

By John G. Elliott and Lauren A. Hammack

U.S. GEOLOGICAL SURVEY

Water-Resources Investigations Report 99-4082

Prepared in cooperation with the NATIONAL PARK SERVICE 


\title{
U.S. DEPARTMENT OF THE INTERIOR BRUCE BABBITT, Secretary
}

\author{
U.S. GEOLOGICAL SURVEY
}

Charles G. Groat, Director

The use of firm, trade, and brand names in this report is for identification purposes only and does not constitute endorsement by the U.S. Geological Survey.

For additional information write to:

District Chief

U.S. Geological Survey

Box 25046, Mail Stop 415

Denver Federal Center

Denver, CO 80225-0046
Copies of this report can be purchased from:

U.S. Geological Survey

Information Services

Box 25286

Federal Center

Denver, CO 80225 


\section{CONTENTS}

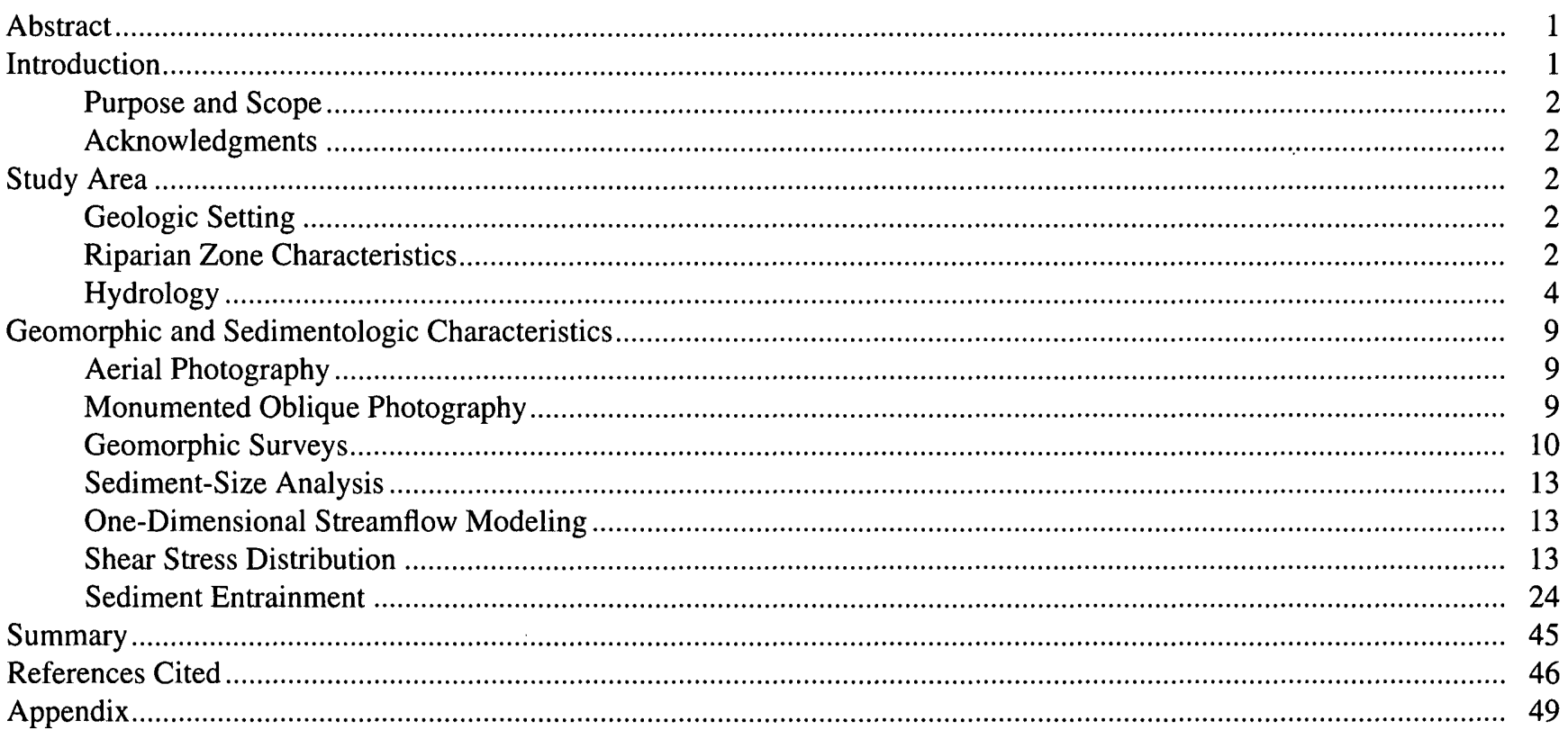

\section{FIGURES}

1. Map of the Gunnison River and the Black Canyon of the Gunnison National Monument, Colorado

2. Photograph showing fluvially deposited bars in the upper part of the Warner Point study reach.

3. Profile of the Gunnison River and graph showing the location and relative abundance of alluvial deposits in Black Canyon of the Gunnison National Monument.

4-5. Maps of:

4. Warner Point study reach showing location of surveyed cross sections and oblique-photography monuments ...... 7

5. Red Rock Canyon study reach showing location of surveyed cross sections and oblique-photography monuments ....

6-9. Plots showing:

6. Channel cross section, shear stress distribution, and critical shear stress for sediment median particle size in the Warner Point study reach

7. Channel cross section, shear stress distribution, and critical shear stress for sediment median particle size in the Red Rock Canyon study reach.

8. Sediment-entrainment potential on similar geomorphic surfaces in the Warner Point study reach ....

9. Sediment-entrainment potential on distal debris-fan surfaces in the Red Rock Canyon study reach ......

10-18. Replicate photographs showing:

10. Warner Point study reach from monument 0011-A, downstream view of Bar 8.2L near cross section V5 ............ 50

11. Warner Point study reach from monument 0020-B, downstream view of Bar 8.5 near cross section H34 ............. 52

12. Warner Point study reach from monument 0021-A, upstream view of Bar 8.5R near cross section H3 ................. 54

13. Warner Point study reach from monument 0021-D, downstream view of Bar 8.5R near cross section $\mathrm{H} 60$........... 56

14. Red Rock Canyon study reach from monument 0003-B2, cross-channel view of bar near cross section G1 ......... 58

15. Red Rock Canyon study reach from monument 0005-D, downstream view of debris fan at Tributary $11.3 \mathrm{R}$........ 60

16. Red Rock Canyon study reach from monument 0006-B, downstream view of bar above cross section $\mathrm{H} 2$............ 62

17. Red Rock Canyon study reach from monument 0010-U, upstream view of debris-fan distal margin near cross section $\mathrm{H} 116$

18. Red Rock Canyon study reach from monument $0011-\mathrm{U}$, upstream view debris-fan distal margin near cross section F118 


\section{TABLES}

1. Streamflow characteristics for the Gunnison River downstream from the Gunnison Tunnel,

U.S. Geological streamflow-gaging station 09128000 .

2. Locations of oblique-photography monuments in the Warner Point and Red Rock Canyon study reaches,

Black Canyon of the Gunnison National Monument .................................................................................. 11

3. Sediment-size statistics and critical shear stress for the median particle size, Warner Point study reach ............. 14

4. Sediment-size statistics and critical shear stress for the median particle size, Red Rock Canyon study reach ...... 16

5. Modeled hydraulic geometry of Warner Point study reach cross sections ...................................................... 17

6. Modeled hydraulic geometry of Red Rock Canyon study reach cross sections ................................................ 21

\section{CONVERSION FACTORS, VERTICAL DATUM, AND ABBREVIATIONS}

\begin{tabular}{rll}
\hline Multiply & By & To obtain \\
\hline millimeter $(\mathrm{mm})$ & 0.03937 & inch \\
foot $(\mathrm{ft})$ & 0.3048 & meter $(\mathrm{m})$ \\
mile $(\mathrm{mi})$ & 1.609 & kilometer $(\mathrm{km})$ \\
square foot $\left(\mathrm{ft}^{2}\right)$ & 0.0929 & square meter \\
square mile $\left(\mathrm{mi}^{2}\right.$ & 2.590 & square kilometer \\
acre-foot $(\mathrm{acre}-\mathrm{ft})$ & 0.001233 & cubic hectometer \\
foot per second $(\mathrm{ft} / \mathrm{s})$ & 0.3048 & meter per second \\
cubic foot per second $\left(\mathrm{ft}^{3} / \mathrm{s}\right)$ & 0.02832 & cubic meter per second \\
pound per square foot $\left(\mathrm{lb} / \mathrm{ft}^{2}\right)$ & 4.882 & kilogram per square meter \\
pound per square foot $\left(\mathrm{lb} / \mathrm{ft}^{2}\right)$ & 47.88 & newton per square meter \\
pound per cubic foot $\left(\mathrm{lb} / \mathrm{ft}^{3}\right)$ & 157.1 & newton per cubic meter $\left(\mathrm{N} / \mathrm{m}^{3}\right)$ \\
\hline
\end{tabular}

Sea level: In this report, "sea level" refers to the National Geodetic Vertical Datum of 1929 (NGVD of 1929)—a geodetic datum derived from a general adjustment of the first-order level nets of both the United States and Canada, formerly called Sea Level Datum of 1929. 


\title{
Geomorphic and Sedimentologic Characteristics of Alluvial Reaches in the Black Canyon of the Gunnison National Monument, Colorado
}

\author{
By John G. Elliott and Lauren A. Hammack ${ }^{1}$
}

\section{ABSTRACT}

The Black Canyon of the Gunnison River in western Colorado includes several alluvial reaches that are potentially sensitive to changes in streamflow. Sediment derived from talus slopes, rockfall, and tributary debris flows periodically is reworked and redeposited on the streambed, streambanks, and alternate bars in these alluvial reaches, providing a growth medium for riparian vegetation. Geomorphic and sedimentologic data were collected and evaluated at two alluvial reaches in the Black Canyon-Warner Point and Red Rock Canyon. These data and the hydrologic data from an upstream gaging station were used to calculate the entrainment potential of a large range of sediment sizes on a variety of fluvial geomorphic surfaces typical of the Gunnison River in the Black Canyon and other canyon rivers.

The HEC-2 and HEC-RAS one-dimensional water-surface profiles models were used to estimate water-surface elevations, flow depths, and hydraulic conditions for discharges from 2,000 to 20,000 cubic feet per second at surveyed channel cross sections in the two study reaches. A peak discharge of 9,470 cubic feet per second in 1995 and onsite observations and photographs in 1994 and 1995 confirmed sediment entrainment or reworking on several geomorphic surfaces inundated by the peak discharge. Physical evidence of sediment entrainment, or absence of sediment entrainment, on inundated sediment-

\footnotetext{
${ }^{1}$ National Park Service, Fort Collins, Colorado.
}

measurement sites generally was consistent with critical shear stresses estimated with a dimensionless critical shear stress, $\tau^{*}{ }_{c}$, of 0.030 in the Warner Point study reach. Sediment-entrainment potential over a range of discharges was summarized by the ratio of boundary shear stress to the critical shear stress $\left(\tau_{\mathrm{o}} / \tau_{\mathrm{c}}\right)$, given local hydraulic geometry and sediment-size characteristics.

Differing entrainment potential for similar geomorphic surfaces indicates that estimation of minimum streamflow requirements based on sediment mobility requires site-specific geomorphic and sedimentologic data.

\section{INTRODUCTION}

The Black Canyon of the Gunnison River is noted for its gorge-like characteristics, which include expansive views, precipitous bedrock cliffs, and a cascading river (Hansen, 1965; Warner and Walker, 1972). However, several reaches of the river through the Black Canyon of the Gunnison National Monument (BLCA) exhibit characteristics of an alluvial river: fluvially deposited banks and bars, riffle-pool channel geometry, and a riparian ecosystem. Although the large-scale features of canyon rivers, such as the Gunnison River in the Black Canyon, are influenced by regional geology, the channel and riparian zone of many canyon river reaches are dominated by fluvial processes. Geomorphic and botanical conditions in the alluvial reaches of canyon rivers are controlled both by the characteristics of fluvially deposited sediment and the hydraulics of flood discharges. Consequently, changes in streamflow can produce adverse effects in canyon rivers similar to those in alluvial rivers (Elliott and Hammack, in press). 


\section{Purpose and Scope}

This report summarizes geomorphic, hydraulic, and sedimentologic data collected in two alluvial reaches of BLCA in 1990, 1994, and 1995 and hydrologic data recorded since the early 20 th century. The geomorphic and sedimentologic data were collected and evaluated by the U.S. Geological Survey (USGS) in cooperation with the National Park Service (NPS). The objective of this study was to determine the hydraulic conditions and minimum streamflow necessary to entrain, or initiate the movement of, the sediment median-particle size $\left(\mathrm{d}_{50}\right)$ of the alluvial streambanks and bars in selected areas of BLCA vulnerable to encroachment by riparian vegetation. The data and these findings will be used by the NPS to assess the sensitivity of the riparian corridor in BLCA to potential changes in the Gunnison River streamflow regime.

The hydrologic data are from streamflow-gaging station 09128000 Gunnison River below Gunnison Tunnel, located at the eastern end of BLCA (fig. 1). This gage, operated by the USGS, has recorded peak discharge since 1906 and continuous streamflow since 1911. Geomorphic data include channel geometry characteristics determined from onsite surveys made with a total-station laser theodolite and sediment-size distributions. Hydraulic data include flow depths and boundary shear stresses at several channel cross sections reconstructed from one-dimensional, watersurface profiles modeling. Sedimentologic data include particle-size analyses of streambanks, alluvial bars, and a tributary debris-flow deposit. Estimates of sediment-entrainment potential were based on the sediment critical shear stress and modeled hydraulic conditions at several locations on the cross sections.

\section{Acknowledgments}

The study was made possible with the support of the National Park Service and the cooperation of the Bureau of Reclamation. Mark Wondzell (NPS) established and surveyed several cross sections in 1990 that were subsequently relocated and resurveyed by the authors. In addition, Mark Wondzell organized logistical support, assisted in all field-data collection efforts, and provided critical oversight of methodology and reviews of the early drafts of this report.
The authors are especially grateful to Myron Chase (NPS) and George Ingersoll (USGS) for their dedication, invaluable logistical support, and assistance in the field. Greg Auble, Jonathan Friedman, and Mike Scott (USGS) contributed critical insight and discussion concerning the sensitivity of riparian vegetation to hydrologic variability. Additional field assistance was provided by Michelle DeLong, Chris Gable, and Erica Van Wie (NPS) and by Randy Parker and Erik Eggleston (USGS). Technical reviews of the report were provided by David F. Meyer and Mark E. . Smith (USGS).

\section{STUDY AREA}

The area generally known as the Black Canyon of the Gunnison River includes the Black Canyon of the Gunnison National Monument (BLCA), the Gunnison Gorge, and reaches now inundated by Blue Mesa, Morrow Point, and Crystal Reservoirs (fig. 1). This study was limited to the BLCA portion of the Black Canyon.

\section{Geologic Setting}

The geology of the Black Canyon area exerts a strong influence on the Gunnison River canyon and fluvial geomorphology in BLCA. Incision of the Gunnison River into folded and faulted areas of the Gunnison uplift has exposed predominantly Precambrian igneous and metamorphic rocks at river level (Hansen, 1965), but variations in the structure and lithology give rise to a variety of canyon and fluvial morphologies. Sediment transported by the river is supplied by local talus slopes and rockfall and by debris flows from ephemeral tributaries (Elliott and Parker, 1997).

\section{Riparian Zone Characteristics}

The Black Canyon riparian zone can be classified into general reach categories determined by the dominant physical processes affecting river morphology and sediment characteristics. The two most common reach categories are talus/rockfall and alluvial. A third reach category, debris flow, is less common although significant geomorphically because of the large volume of mixed-size sediment delivered 


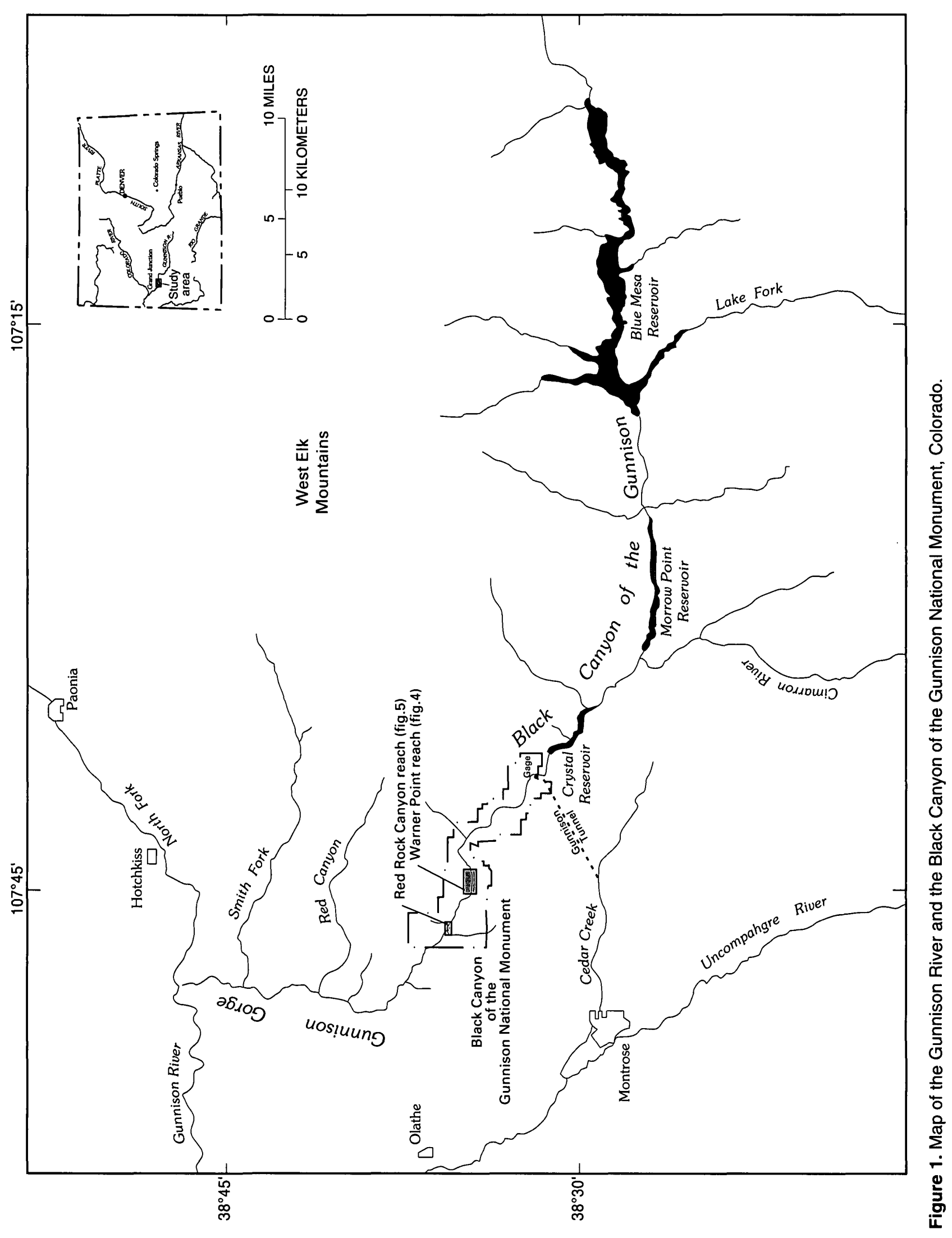

STUDY AREA 3 
to the river. Debris flows from ephemeral tributaries occur intermittently in both talus/rockfall and alluvial reaches of BLCA.

Talus/rockfall reaches have steep river gradients and very narrow canyon floors bordered by steep talus or colluvial slopes and sheer bedrock cliffs. The streambed and banks in these reaches are composed of a high proportion of large, angular rock fragments that have fallen directly into the channel and generally remain there. These reaches have limited, if any, deposits of finer grain, fluvially deposited sediments where riparian plant communities can develop. Talus/rockfall is the predominant reach category in BLCA; photographic interpretation indicates that the riparian zone in these reaches has changed very little since 1939.

In other river reaches in BLCA, substantial portions of the channel bed and banks are composed of fluvially transported and deposited sand, gravel, cobbles, and boulders. These are alluvial reaches. Streambanks composed of well-rounded gravel and cobbles are more prominent in these reaches than in talus/rockfall reaches, and fluvially deposited bars can be as much as several tens of feet wide (fig. 2). Alluvial deposits of notable size are present in the upper and lower reaches of BLCA but generally are absent between river mile (RM) 4.6 upstream from The Narrows and RM 7.1 upstream from The Painted Wall where the river gradient is very steep (fig. 3 ). River miles in this report are expressed as the downstream distance measured from the Gunnison Tunnel diversion in the eastern part of BLCA (fig. 1).

The Gunnison River profile (fig. 3) over a 13-mile segment from the Gunnison Tunnel Diversion to the western boundary of BLCA (fig. 1) was derived from USGS 1:24,000 topographic maps with 20- and 40 -foot contour intervals. Superimposed on the river profile in figure 3 is a graph showing the percentage of the river reach between adjacent contour crossings bounded by alluvial deposits. Aerial-photograph interpretation indicates that approximately 35 percent of the Gunnison River in BLCA is bordered on one or both banks by alluvial sedimentary deposits.

The greater abundance of fluvial sediments deposited in alluvial reaches provides a growth medium for riparian vegetation and the gravel- and cobble-size bed material that is critical for some aquatic biota. Alluvial reaches, in contrast to talus/rockfall reaches, are areas dominated by streamflow-dependent processes, including intermittent sedi- ment transport, storage, and remobilization. Consequently, the fluvial geomorphology, riparian vegetation, and bed-material composition in alluvial reaches are more sensitive to streamflow-regime modification caused by climate change or anthropogenic activity. Some alluvial reaches have exhibited noticeable geomorphic and vegetation changes since the first aerial photographs were taken of BLCA in 1939.

Two alluvial reaches of BLCA were studied. The Warner Point study reach (fig. 4) extended from RM 8.1 to RM 8.7, and the Red Rock Canyon study reach (fig. 5) extended from RM 10.9 to 11.4 (fig. 3). Talus/rockfall reaches were not included in this study because of their relative insensitivity to streamflowregime modification.

\section{Hydrology}

The Gunnison River Basin has a drainage area of almost $8,000 \mathrm{mi}^{2}$ at its confluence with the Colorado River at Grand Junction, Colorado, and contributes 42 percent of the Colorado River annual streamflow at the Colorado/Utah State line. Most of the main-stem runoff is generated by spring snowmelt; however, convective and monsoonal summer storms generate runoff in ephemeral tributaries in the lower parts of the watershed (Elliott and Parker, 1992).

Four major reservoirs and one transbasin diversion affect streamflow entering the Black Canyon. Blue Mesa Reservoir, completed in October 1965, Morrow Point Reservoir (1968), and Crystal Reservoir (1977) comprise the Wayne N. Aspinall Unit, a group of three large reservoirs in the central part of the Gunnison River Basin just upstream from BLCA (fig. 1). The three reservoirs of the Aspinall Unit have a combined storage capacity of about 52 percent of the average annual streamflow of the Gunnison River. Diversion and impoundment before water year 1966 had relatively little effect on the flood hydrology of the Black Canyon. Impoundment by Blue Mesa Reservoir has had a substantial effect on the downstream flow regime; therefore, the postregulation period for the purpose of this study is defined as 1966 to the present (Elliott and Parker, 1997).

The USGS streamflow-gaging station 09128000, Gunnison River below Gunnison Tunnel, has recorded peak discharge since 1906 and continuous discharge since 1911. The gage is located approximately 2.3 miles downstream from Crystal 


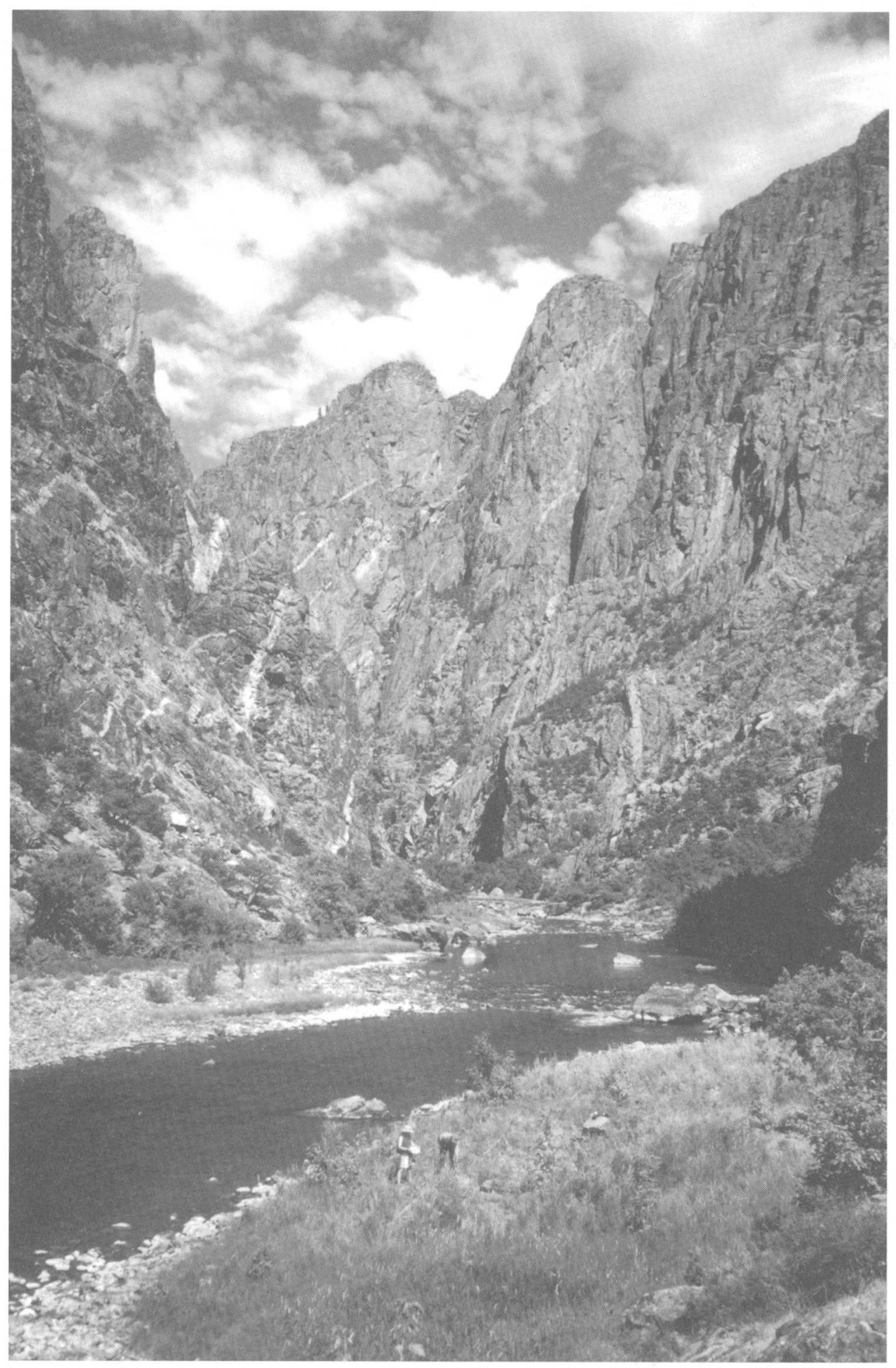

Figure 2. Photograph showing fluvially deposited bars in the upper part of the Warner Point study reach. Photograph taken from monument location 0004 (see fig. 4), July 31,1994 ; discharge was approximately 300 cubic feet per second. 


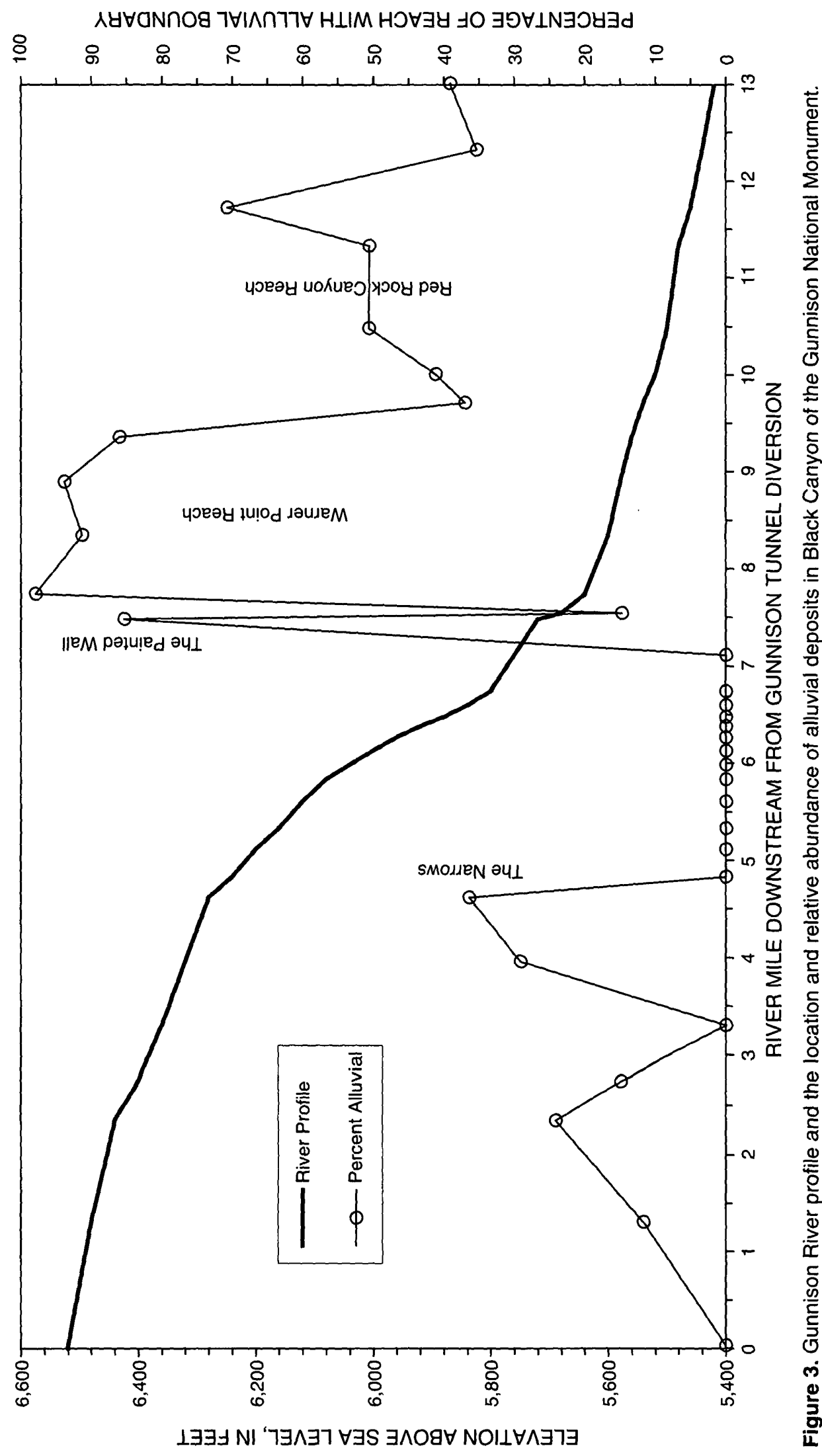




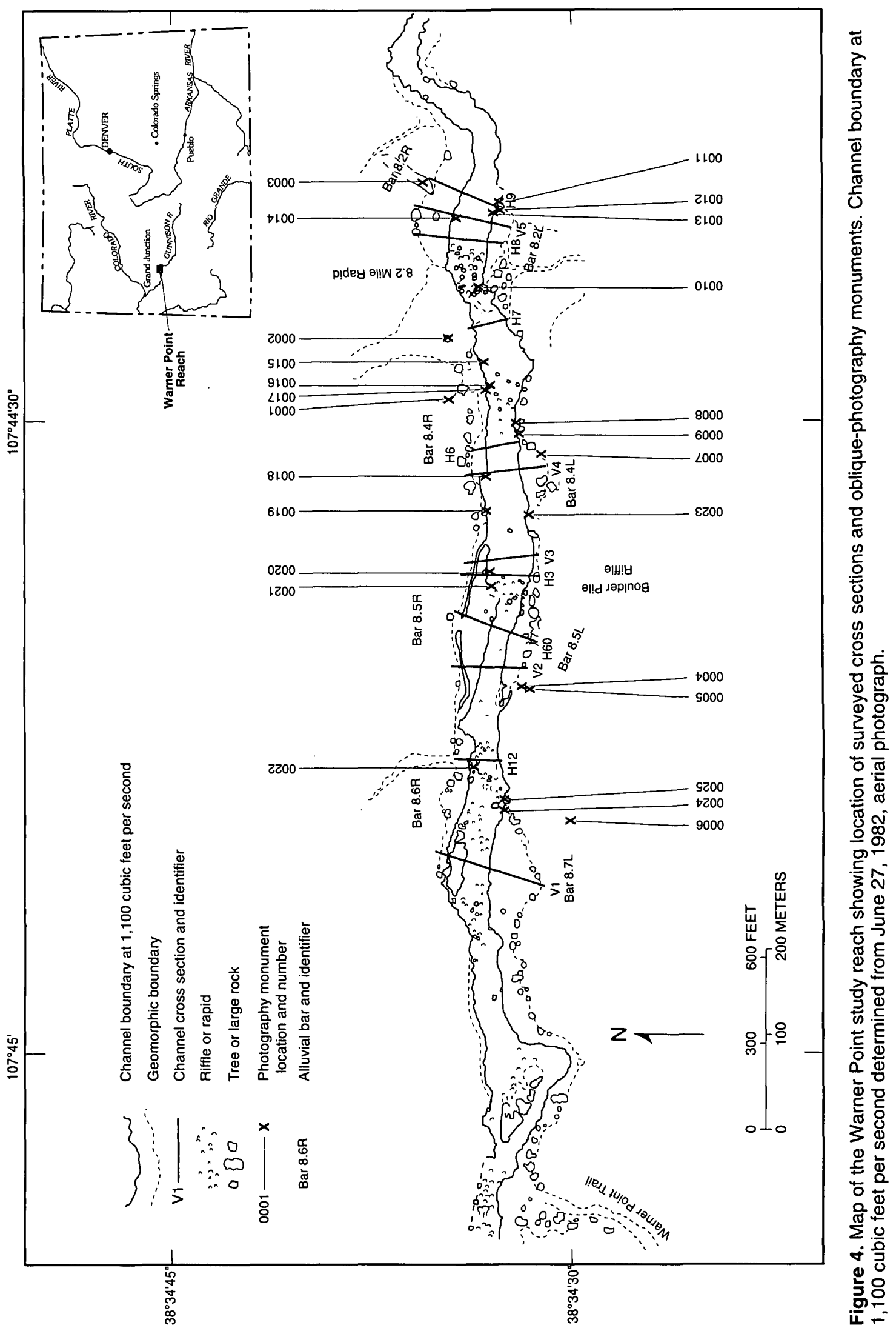




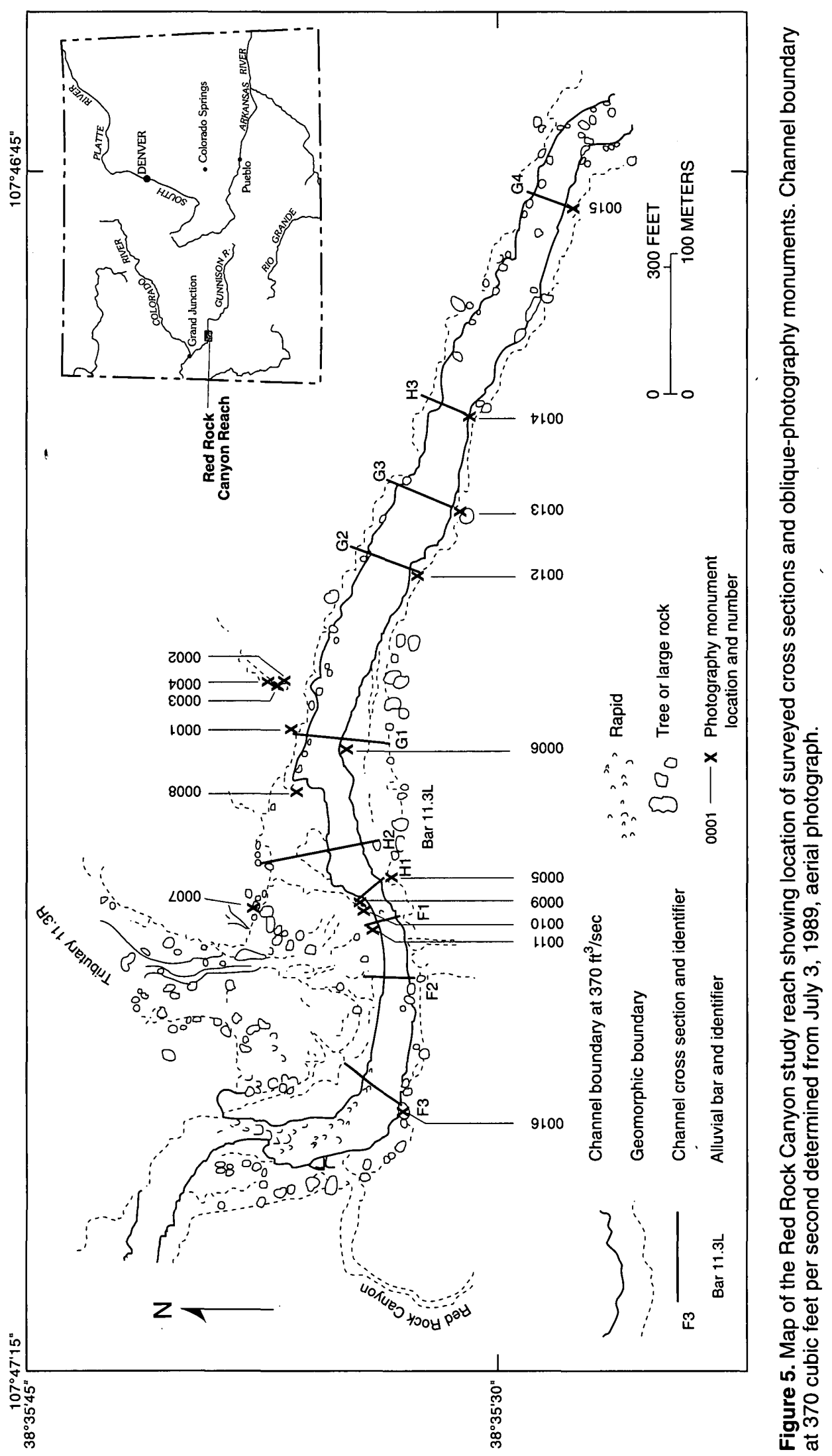


Dam (the downstream-most of the Aspinall Unit dams), about 0.4 mile downstream from the Gunnison Tunnel (fig. 1), and 8.2 miles upstream from the beginning of the Warner Point study reach. The Gunnison Tunnel diverts as much as approximately $1,000 \mathrm{ft}^{3} / \mathrm{s}$ for irrigation from April through October. The nonconsumed portion of the diverted water eventually is returned to the Gunnison River by way of the Uncompahgre River and does not pass through the Black Canyon. The drainage area upstream from the gage is $3,965 \mathrm{mi}^{2}$. Discharge data from 1911 through 1994 were used to determine magnitude-frequency relations and flow-duration characteristics for periods before (preregulation) and after (postregulation) reservoir construction.

Upstream reservoirs have altered the timing and magnitude of Gunnison River flood peaks since 1966; however, the mean annual discharge in the Black Canyon (954,000 acre-feet) has not changed since about 1930. Monthly mean discharge during the snowmelt season (April through July) has decreased 63 percent since reservoir regulation, whereas monthly mean discharge for the remainder of the year (August through March) has increased 170 percent (Elliott and Parker, 1992). Flood magnitudes of given recurrence intervals (RI) have decreased substantially since 1966. Recurrence intervals, the reciprocal of the probability that a specific discharge will be equaled or exceeded in any given year, were determined according to methods prescribed by the U.S. Interagency Advisory Committee on Water Data (1982). The 10-year flood decreased from 14,900 to $7,000 \mathrm{ft}^{3} / \mathrm{s}$, the 5-year flood from 12,700 to $5,460 \mathrm{ft}^{3} / \mathrm{s}$, and the mean annual flood from 9,290 to $4,040 \mathrm{ft}^{3} / \mathrm{s}$. While reservoir operation has attenuated flood peaks in the Black Canyon, it also has augmented moderate streamflows. The duration of daily mean streamflows between 1,140 and $3,000 \mathrm{ft}^{3} / \mathrm{s}$ has increased from an average of 12 percent of the time, or an average of about 44 days per year from 1911 to 1965 , to 38 percent of the time, or an average of about 139 days per year from 1966 to 1994 (Elliott and Parker, 1997). Recurrence intervals and streamflow durations of selected discharges in the preregulation and postregulation periods are summarized in table 1 .

\section{GEOMORPHIC AND SEDIMENTOLOGIC CHARACTERISTICS}

Geomorphic and sedimentologic data were collected and evaluated at two alluvial reaches in the BLCA. These data and the hydrologic data from the upstream gaging station were used to calculate the entrainment potential of a large range of sediment sizes on a variety of fluvial geomorphic surfaces typical of the Gunnison River in the Black Canyon and other canyon rivers.

\section{Aerial Photography}

Aerial and oblique photography have been used to document changes in geomorphology and riparian conditions by several investigators (Webb, 1996; Webb and others, 1996; Elliott and Hammack, in press). Aerial photography was used to identify alluvial and talus/rockfall reaches of BLCA and to evaluate changes in alluvial deposits, debris-flow deposits, and riparian vegetation through time. Black and white, natural color, and color/infrared images covering part or all of BLCA have been made intermittently since 1939. Most of these photographs were made in the late summer or early autumn and facilitate comparison of fluvial features at relatively low discharges. Years of photography used in this study are $1939,1950,1954$, 1966, 1976, 1982, 1989, and 1992. An index of most of these aerial photographs is available from the USGS Earth Science Information Center in Denver, Colorado.

\section{Monumented Oblique Photography}

Oblique photographs were taken of the study reaches, monumented cross sections, alluvial bars, and sediment-sampling sites and can be used to document future changes in alluvial features if they occur. Photographs of the BLCA study reaches were made from monumented vantage points at river level to at least 100 feet above the river level to show different perspectives of the Gunnison River. Several changes in riparian vegetation and sediment deposits in the two study reaches were observed and photographed between 1994 and 1995 and confirm sediment entrainment at several locations (Elliott and Hammack, in press). Monumented photography locations and numbers are shown in figures 4 and 5 and are listed in 
Table 1. Streamflow characteristics for the Gunnison River downstream from the Gunnison Tunnel, U.S. Geological streamflow-gaging station 09128000

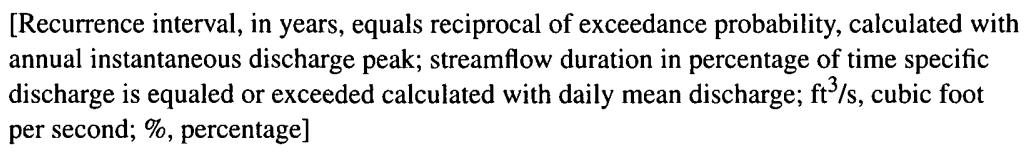

\begin{tabular}{|c|c|c|c|c|}
\hline \multirow[b]{2}{*}{$\begin{array}{c}\text { Discharge } \\
\left(\mathrm{ft}^{3} / \mathrm{s}\right)\end{array}$} & \multicolumn{2}{|c|}{ Recurrence interval } & \multicolumn{2}{|c|}{ Streamflow duration } \\
\hline & $\begin{array}{c}\text { Pre- } \\
\text { regulation } \\
\text { 1911-65 } \\
\text { (years) }\end{array}$ & $\begin{array}{c}\text { Post- } \\
\text { regulation } \\
\text { 1966-94 } \\
\text { (years) }\end{array}$ & $\begin{array}{c}\text { Pre- } \\
\text { regulation } \\
\text { 1911-65 } \\
\text { (\% time) }\end{array}$ & $\begin{array}{c}\text { Post- } \\
\text { regulation } \\
\text { 1966-94 } \\
\text { (\% time) }\end{array}$ \\
\hline 300 & & & 80 & 80 \\
\hline 500 & & & 51 & 65 \\
\hline 1,000 & & 1.01 & 28 & 47 \\
\hline 1,140 & & 1.02 & 26 & 42 \\
\hline 2,000 & & 1.18 & 19 & 17 \\
\hline 2,200 & 1.01 & 1.25 & 18 & 12 \\
\hline 3,000 & 1.04 & 1.65 & 14 & 4.0 \\
\hline 4,000 & 1.09 & 2.5 & 11 & 1.2 \\
\hline 5,000 & 1.17 & 4.0 & 7.9 & 0.72 \\
\hline 5,140 & 1.18 & 4.2 & 7.5 & 0.70 \\
\hline 6,000 & 1.30 & 6.0 & 5.8 & 0.60 \\
\hline 7,000 & 1.50 & 10 & 4.1 & 0.46 \\
\hline 8,000 & 1.70 & 16 & 2.8 & 0.28 \\
\hline 9,000 & 2.0 & 24 & 1.9 & 0.13 \\
\hline 10,000 & 2.5 & 35 & 1.2 & 0.03 \\
\hline 11,000 & 3.2 & 50 & 0.8 & \\
\hline 12,000 & 4.4 & 75 & 0.5 & \\
\hline 13,000 & 6.0 & 100 & 0.3 & \\
\hline 14,000 & 8.0 & & 0.16 & \\
\hline 15,000 & 11 & & 0.09 & \\
\hline 16,000 & 16 & & & \\
\hline 17,000 & 24 & & & \\
\hline 18,000 & 35 & & & \\
\hline 19,000 & 55 & & & \\
\hline 20,000 & 90 & & & \\
\hline
\end{tabular}

table 2. A complete set of photographs taken from these locations is in the possession of the NPS Water Resources Division in Fort Collins, Colorado, and selected photographs are presented in the appendix at the end of this report.

\section{Geomorphic Surveys}

Surveys were made of the study reaches with a total-station laser theodolite to quantify geomorphic features, high-water elevations, channel cross-section characteristics, and river gradient. Data from these surveys also were used as input to one-dimensional, water-surface profile models and sediment-entrainment potential calculations. The Warner Point study reach (fig. 4) was approximately 3,000 ft long and was surveyed in 1990, 1994, and 1995. Twelve channel cross sections were surveyed in the Warner Point reach and were used to calibrate the one-dimensional, watersurface profile model. Hydraulic-geometry characteristics and sediment-entrainment potential were calculated at 8 of the 12 cross sections. Geomorphic features surveyed included streambanks, alluvial bars, and overflow channels between the bars and adjacent talus slopes. 


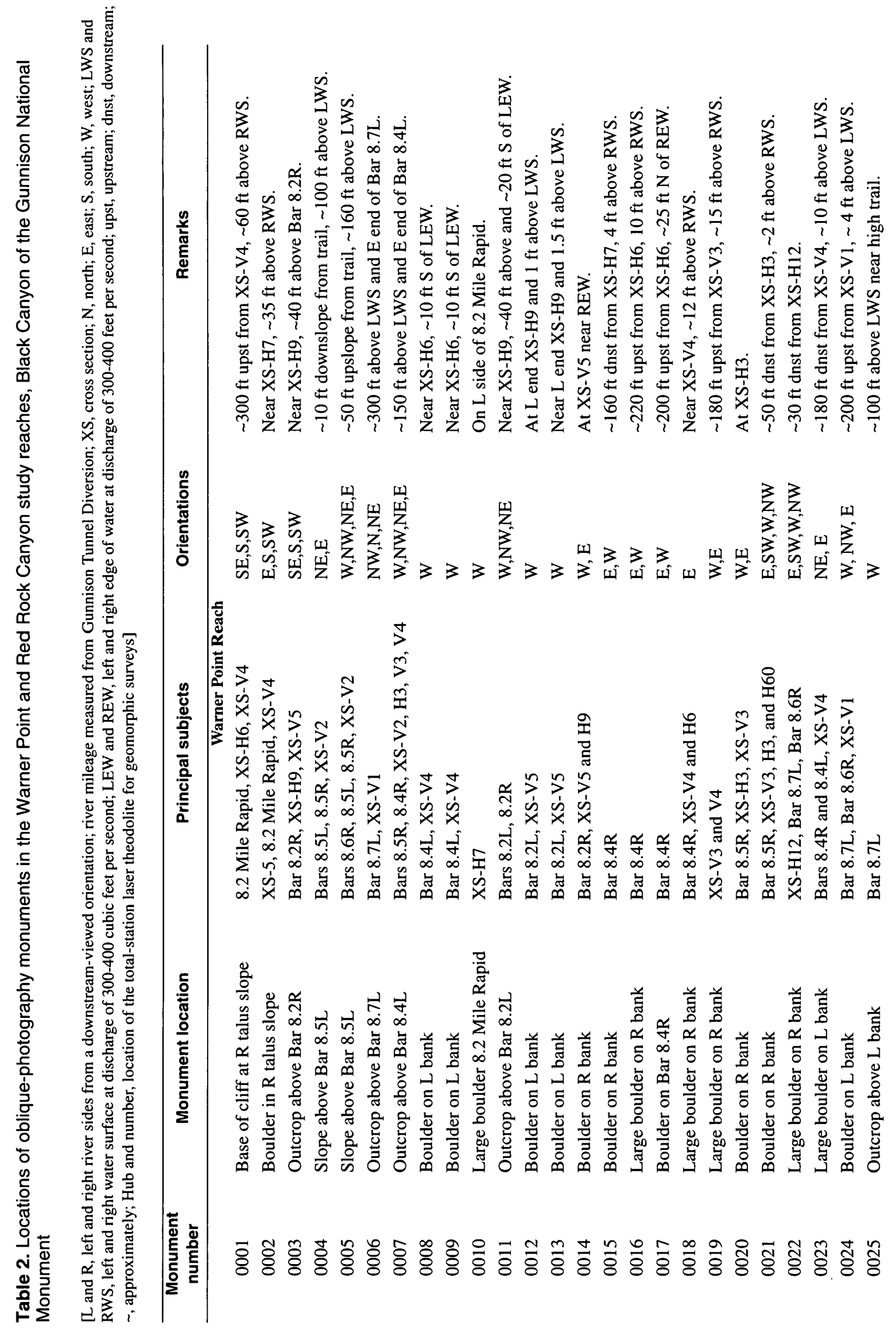




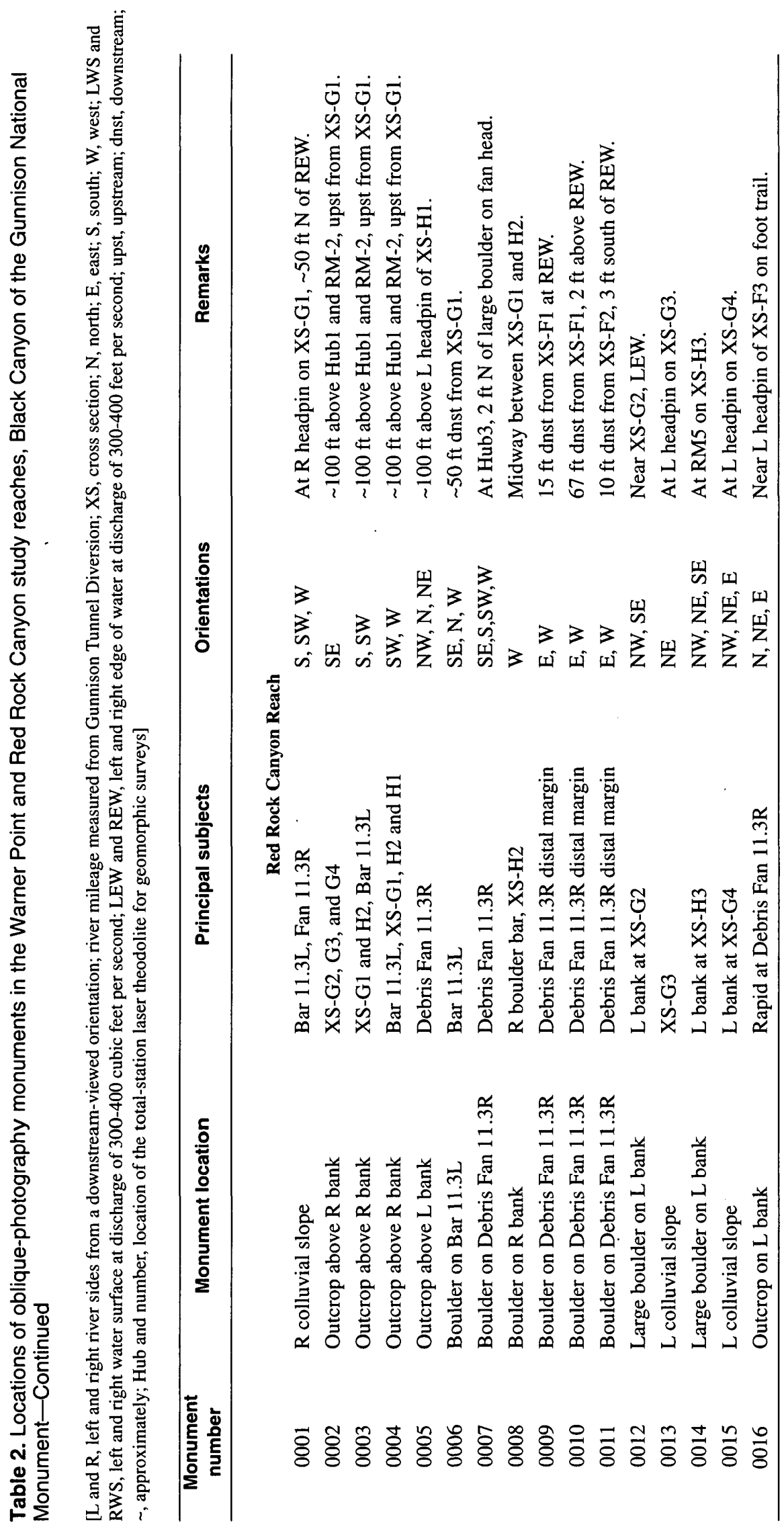


The Red Rock Canyon study reach (fig. 5) was approximately $2,300 \mathrm{ft}$ long and was surveyed in 1994; selected cross sections were resurveyed in 1995. Ten channel cross sections were surveyed in the Red Rock Canyon reach and were used to calibrate the one-dimensional, water-surface profiles model. Hydraulic-geometry characteristics were calculated at 6 of the 10 cross sections, and sediment-entrainment potential was calculated at 4 cross sections. Geomorphic features surveyed included streambanks, alluvial bars, and the distal margin of a tributary debris fan.

\section{Sediment-Size Analysis}

Sediment-size characteristics, including the median particle size $\left(d_{50}\right)$, were determined for a variety of surfaces deemed geomorphically distinct and (or) botanically significant using the Wolman (1954) method. These surfaces included the streambed and streambanks, the lateral and top surfaces of large alluvial bars, and the distal margin of a debris-flow deposit (tables 3 and 4). The streambed and low-flow channel of most cross sections in the study reaches are composed of material in the large cobble- and bouldersize range; however, streambanks and alluvial bars are composed of finer material in the gravel-, cobble-, and occasionally boulder-size range. Most of the initial sediment measurements were made in 1994; however, a few sites were first measured in 1995. Replicate measurements were made in 1995 at several sites initially measured in 1994 to determine the effect of the 1995 peak discharge $\left(9,470 \mathrm{ft}^{3} / \mathrm{s}\right)$ on sediment-size characteristics. Subsurface sediment size was not determined except for the left bank at cross section V4 in the Warner Point study reach, where the ratio of surface $\mathrm{d}_{50}(47 \mathrm{~mm})$ to subsurface $\mathrm{d}_{50}(20 \mathrm{~mm})$ was 2.35 , within the range stated by Parker and others (1982) as typical for streams having gravel and cobble beds.

\section{One-Dimensional Streamflow Modeling}

The one-dimensional water-surface profiles model HEC-2 (Hydrologic Engineering Center, 1990) was used to estimate water-surface elevations, flow depths, and hydraulic conditions through the study reaches for a range of discharges from 2,000 to $20,000 \mathrm{ft}^{3} / \mathrm{s}$. The model used surveyed channel cross sections and was calibrated with observed watersurface elevations and high-water marks associated with discharges of $336,614,766,1,024,1,584,3,450$, $5,170,6,800$, and $9,400 \mathrm{ft}^{3} / \mathrm{s}$ in the Warner Point reach. HEC-RAS (Hydrologic Engineering Center, 1997) was used to model the Red Rock Canyon reach. This model was calibrated using discharges of 400 , $1,000,2,310$, and $3,170 \mathrm{ft}^{3} / \mathrm{s}$. Discharges at the Warner Point and Red Rock Canyon reaches were assumed to be comparable to discharges recorded a few hours earlier at USGS gaging station 09128000 upstream.

The hydraulic models were calibrated by varying the Manning's $n$ roughness coefficient until the calculated water-surface elevations matched the surveyed water-surface elevations as closely as possible. Calculated water-surface elevations were within 0.2 to $0.5 \mathrm{ft}$ of the surveyed elevations for most calibration discharges, having differences less than 10 percent of the calculated flow depth for a specific discharge. Although the Manning's n roughness coefficient was used as a calibration tool, reasonable values for each cross section were maintained based on estimated values from Barnes (1967) and Arcement and Schneider (1989).

Computational errors were minimized, and the accuracy of the models was improved by inserting interpolated cross sections to balance velocity heads and water-surface elevations. Additionally, multiple friction loss equations were evaluated, and conveyance ratios were kept within tolerances where possible and were otherwise determined acceptable. Hydraulic output from the modeling runs included water-surface elevations and energy gradients, from which flow depths and boundary shear stresses at specific locations on the cross sections were calculated. Tables 5 and 6 summarize hydraulic-geometry characteristics in the study reaches for simulated discharges.

\section{Shear Stress Distribution}

Sediment entrainment in stream channels is partly a function of the boundary shear stress acting on sediment particles resting on or in the streambed or other inundated alluvial surfaces. Shear stress is proportional to the square of streamflow velocity and is most accurately determined by measurements of velocity vectors in downstream, lateral, and vertical directions. When velocity data are unavailable, mean shear stress in a channel cross section commonly is 
Table 3. Sediment-size statistics and critical shear stress for the median particle size, Warner Point study reach

[Station, sample location on cross section from left endpoint; Percentile, percentile of the size distribution; lc, sampled across the entire low-flow channel; $\mathrm{ns}$, not sampled or not calculated; Critical shear for the median sediment size calculated with equation 2; Shields parameter is variable depending on pavement and subsurface properties; $\mathrm{ft}$, foot; $\mathrm{mm}$, millimeters; $\mathrm{lb} / \mathrm{ft}^{2}$, pound per square foot]

\begin{tabular}{|c|c|c|c|c|c|c|c|c|c|c|}
\hline $\begin{array}{l}\text { Cross } \\
\text { section }\end{array}$ & $\begin{array}{l}\text { Sample } \\
\text { year }\end{array}$ & $\begin{array}{l}\text { Sample } \\
\text { code }\end{array}$ & $\begin{array}{l}\text { Station } \\
\text { (ft) }\end{array}$ & $\begin{array}{c}\text { 16th } \\
\text { Percen- } \\
\text { tile } \\
(\mathrm{mm})\end{array}$ & $\begin{array}{c}\text { 50th } \\
\text { Percen- } \\
\text { tile } \\
(\mathbf{m m})\end{array}$ & $\begin{array}{c}\text { 84th } \\
\text { Percen- } \\
\text { tile } \\
(\mathrm{mm})\end{array}$ & $\begin{array}{c}\text { Maximum } \\
\text { particle } \\
\text { size } \\
(\mathbf{m m})\end{array}$ & $\begin{array}{l}\text { Critical } \\
\text { shear } \\
\text { with } \\
\text { Shields } \\
\text { param- } \\
\text { eter } \\
0.030 \\
\left(\mathrm{lb} / \mathrm{ft}^{2}\right)\end{array}$ & $\begin{array}{l}\text { Critical } \\
\text { shear } \\
\text { with } \\
\text { Shields } \\
\text { param- } \\
\text { eter } \\
0.045 \\
\left(\mathrm{lb} / \mathrm{ft}^{2}\right)\end{array}$ & Remarks \\
\hline V1 & 1994 & XChan & lc & 90 & 230 & 420 & 1,450 & 2.33 & 3.50 & $\begin{array}{l}\text { Sampled from station } 196 \\
\text { to } 358 \text {. }\end{array}$ \\
\hline V1 & 1994 & LBldBar & 138 & 60 & 130 & 300 & 700 & 1.32 & 1.98 & \\
\hline V1 & 1994 & LBank & 198 & 105 & 240 & 400 & 660 & 2.43 & 3.65 & \\
\hline V1 & 1994 & RBIdBar & 287.5 & 50 & 180 & 370 & 750 & 1.82 & 2.74 & $\begin{array}{l}\text { Sampled near right edge of } \\
\text { water. }\end{array}$ \\
\hline $\mathrm{V} 2$ & ns & XChan & ns & ns & ns & ns & 740 & ns & ns & $\begin{array}{l}\text { Low-flow channel not } \\
\text { sampled. }\end{array}$ \\
\hline V2 & 1994 & LBldBar & 66 & 160 & 270 & 400 & 600 & 2.74 & 4.11 & \\
\hline V2 & 1994 & LBank & 81 & 100 & 212 & 450 & 600 & 2.15 & 3.22 & \\
\hline V2 & 1994 & RBank & 161 & 80 & 125 & 190 & 280 & 1.27 & 1.90 & \\
\hline V2 & 1994 & RSlope & 168 & 55 & 98 & 170 & 380 & 0.99 & 1.49 & Midway up bar slope. \\
\hline $\mathrm{V} 2$ & 1994 & RBldBar & 186 & 50 & 125 & 200 & 400 & 1.27 & 1.90 & \\
\hline $\mathrm{V} 2$ & 1994 & ROvrFlo & 228 & 31 & 140 & 210 & 400 & 1.42 & 2.13 & \\
\hline $\mathrm{V} 2$ & 1995 & LBank & 80 & 34 & 128 & 224 & 410 & 1.30 & 1.95 & \\
\hline $\mathrm{V} 2$ & 1995 & RBank & 161 & 46 & 98 & 145 & 520 & 0.99 & 1.49 & \\
\hline V2 & 1995 & RSlope & 168 & 52 & 100 & 158 & 225 & 1.01 & 1.52 & \\
\hline H60 & $\mathrm{ns}$ & XChan & ns & ns & ns & $\mathrm{ns}$ & ns & ns & $\mathrm{ns}$ & $\begin{array}{l}\text { Low-flow channel not } \\
\text { sampled. }\end{array}$ \\
\hline H60 & 1994 & LBank & 87 & 25 & 130 & 390 & 700 & 1.32 & 1.98 & \\
\hline H60 & 1995 & RBank & 172 & 55 & 180 & 333 & 820 & 1.82 & 2.74 & \\
\hline H60 & 1995 & RBldBar & 192 & 65 & 172 & 472 & 670 & 1.74 & 2.62 & \\
\hline $\mathrm{H} 3$ & ns & XChan & ns & ns & ns & ns & ns & ns & ns & $\begin{array}{l}\text { Low-flow channel not } \\
\text { sampled. }\end{array}$ \\
\hline $\mathrm{H} 3$ & 1994 & RBank & 195 & 18 & 90 & 185 & 1,000 & 0.91 & 1.37 & $\begin{array}{l}\text { Sample overlaps both V3 } \\
\text { and } \mathrm{H} 3 \text {. }\end{array}$ \\
\hline $\mathrm{H} 3$ & 1995 & RBank & 196 & 49 & 110 & 191 & 1,240 & 1.12 & 1.67 & $\begin{array}{l}\text { Sample overlaps both V3 } \\
\text { and } \mathrm{H} 3 \text {. }\end{array}$ \\
\hline V3 & 1994 & XChan & lc & 5 & 150 & 310 & 500 & 1.52 & 2.28 & $\begin{array}{l}\text { Sampled from station } 42 \text { to } \\
205 \text {. }\end{array}$ \\
\hline V3 & 1994 & LBank & 44 & 2 & 14 & 67 & 370 & 0.14 & 0.21 & $\begin{array}{l}\text { Gravel in backwater of } \\
\text { Boulder Pile Riffle. }\end{array}$ \\
\hline V3 & 1994 & RBank & 203 & 18 & 90 & 185 & 1,000 & 0.91 & 1.37 & $\begin{array}{l}\text { Sample overlaps both V3 } \\
\text { and } \mathrm{H} 3 \text {. }\end{array}$ \\
\hline V3 & 1994 & RBIdBar & 211 & $\mathrm{~ns}$ & ns & ns & 320 & 0.00 & 0.00 & \\
\hline V3 & 1995 & LBar & 21 & 41 & 80 & 149 & 2,410 & 0.81 & 1.22 & \\
\hline
\end{tabular}


Table 3. Sediment-size statistics and critical shear stress for the median particle size, Warner Point study reach—Continued

[Station, sample location on cross section from left endpoint; Percentile, percentile of the size distribution; lc, sampled across the entire low-flow channel; $\mathrm{ns}$, not sampled or not calculated; Critical shear for the median sediment size calculated with equation 2; Shields parameter is variable depending on pavement and subsurface properties; $\mathrm{ft}$, foot; $\mathrm{mm}$, millimeters; $\mathrm{lb} / \mathrm{ft}^{2}$, pound per square foot]

\begin{tabular}{|c|c|c|c|c|c|c|c|c|c|c|}
\hline $\begin{array}{l}\text { Cross } \\
\text { section }\end{array}$ & $\begin{array}{l}\text { Sample } \\
\text { year }\end{array}$ & $\begin{array}{c}\text { Sample } \\
\text { code }\end{array}$ & $\begin{array}{l}\text { Station } \\
(\mathrm{ft})\end{array}$ & $\begin{array}{c}\text { 16th } \\
\text { Percen- } \\
\text { tile } \\
(\mathrm{mm})\end{array}$ & $\begin{array}{l}\text { 50th } \\
\text { Percen- } \\
\text { tile } \\
(\mathrm{mm})\end{array}$ & $\begin{array}{l}\text { 84th } \\
\text { Percen- } \\
\text { tile } \\
(\mathbf{m m})\end{array}$ & $\begin{array}{c}\text { Maximum } \\
\text { particle } \\
\text { size } \\
(\mathbf{m m})\end{array}$ & $\begin{array}{l}\text { Critical } \\
\text { shear } \\
\text { with } \\
\text { Shields } \\
\text { param- } \\
\text { eter } \\
0.030 \\
\left(\mathrm{lb} / \mathrm{ft}^{2}\right)\end{array}$ & $\begin{array}{l}\text { Critical } \\
\text { shear } \\
\text { with } \\
\text { Shields } \\
\text { param- } \\
\text { eter } \\
0.045 \\
\left(\mathrm{lb} / \mathrm{ft}^{2}\right)\end{array}$ & Remarks \\
\hline V3 & 1995 & RBank & 204 & 49 & 110 & 191 & 1,240 & 1.12 & 1.67 & $\begin{array}{l}\text { Sample overlaps both V3 } \\
\text { and } \mathrm{H} 3 \text {. }\end{array}$ \\
\hline V3 & 1995 & ROvrFlo & 241 & 8 & 40 & 76 & 760 & 0.41 & 0.61 & \\
\hline V4 & 1994 & XChan & lc & 100 & 270 & 680 & 830 & 2.74 & 4.11 & $\begin{array}{l}\text { Sampled from station } 79 \text { to } \\
205 \text {. }\end{array}$ \\
\hline V4 & 1994 & LGrsTer & 75 & 2 & 9 & 22 & 92 & & & \\
\hline V4 & 1994 & LCblBar & 81 & 2 & 20 & 48 & 101 & 0.20 & 0.30 & $\begin{array}{l}\text { Subsurface sample, } \\
\text { 300-mm-deep pit. }\end{array}$ \\
\hline V4 & 1994 & LBank & 85 & 22 & 47 & 118 & 490 & 0.48 & 0.71 & \\
\hline V4 & 1994 & RCblBar & 203 & 32 & 72 & 165 & 900 & 0.73 & 1.09 & \\
\hline V4 & 1994 & ROvrFlo & 235 & 17 & 87 & 245 & 580 & 0.88 & 1.32 & \\
\hline V4 & 1995 & LBank & 80 & 2 & 38 & 97 & 470 & 0.39 & 0.58 & \\
\hline V4 & 1995 & ROvrFlo & 243 & 39 & 170 & 320 & 1,000 & 1.72 & 2.59 & \\
\hline H6 & 1994 & REddy & 162 & 9 & 16 & 23 & 38 & 0.16 & 0.24 & $\begin{array}{l}\text { Gravel deposited in } 1993 \\
\text { behind large boulder. }\end{array}$ \\
\hline H6 & 1995 & REddy & 162 & 15 & 58 & 162 & 300 & 0.59 & 0.88 & \\
\hline $\mathrm{H} 7$ & 1994 & LBank & 24 & ns & ns & ns & 900 & 0.00 & 0.00 & \\
\hline H8 & 1995 & ROvrFlo & 283 & 10 & 25 & 42 & 60 & 0.25 & 0.38 & \\
\hline V5 & 1994 & XChan & lc & 70 & 250 & 410 & 550 & 2.53 & 3.80 & $\begin{array}{l}\text { Sampled from station } 75 \text { to } \\
219 \text {. }\end{array}$ \\
\hline V5 & 1994 & LSplay & 56 & 35 & 55 & 74 & 205 & 0.56 & 0.84 & \\
\hline V5 & 1994 & LBank & 80 & 128 & 220 & 350 & 530 & 2.23 & 3.35 & \\
\hline V5 & 1994 & RBank & 216 & 38 & 145 & 300 & 550 & 1.47 & 2.20 & \\
\hline V5 & 1994 & RGvlTer & 273 & 14 & 32 & 52 & 120 & 0.32 & 0.49 & $\begin{array}{l}\text { Downstream from Box } \\
\text { Elder number } 132 .\end{array}$ \\
\hline V5 & 1994 & RPtBar & 277 & 26 & 64 & 105 & 500 & 0.65 & 0.97 & \\
\hline V5 & 1995 & LBar & 61 & 2 & 160 & 306 & 455 & 1.62 & 2.43 & \\
\hline V5 & 1995 & $\mathrm{RPtBar}$ & 275 & 11 & 50 & 110 & 430 & 0.51 & 0.76 & \\
\hline H9 & ns & XChan & ns & ns & ns & ns & ns & ns & ns & $\begin{array}{l}\text { Low-flow channel not } \\
\text { sampled. }\end{array}$ \\
\hline H9 & 1994 & LBank & 86 & 128 & 220 & 350 & 530 & 2.23 & 3.35 & Sampled at V5. \\
\hline H9 & 1994 & RBank & 216 & 38 & 145 & 300 & 550 & 1.47 & 2.20 & Sampled at V5. \\
\hline $\mathrm{H} 9$ & 1994 & RPtBar & 277 & 26 & 64 & 105 & 500 & 0.65 & 0.97 & Sampled at V5 \\
\hline H9 & 1995 & RPtBar & 275 & 11 & 50 & 110 & 430 & 0.51 & 0.76 & Sampled at V5. \\
\hline
\end{tabular}


Table 4. Sediment-size statistics and critical shear stress for the median particle size, Red Rock Canyon study reach

[Station, sample location on cross section from left endpoint; Percentile, percentile of the size distribution; lc, sampled across the entire low-flow channel; Critical shear for the median sediment size calculated with Equation 2; Shields parameter is variable depending on pavement and subsurface properties; $\mathrm{ft}$, foot; $\mathrm{mm}$, millimeters; $\mathrm{lb} / \mathrm{ft}^{2}$, pound per square foot; DF, debris flow]

\begin{tabular}{|c|c|c|c|c|c|c|c|c|c|c|}
\hline $\begin{array}{l}\text { Cross } \\
\text { section }\end{array}$ & $\begin{array}{l}\text { Sample } \\
\text { year }\end{array}$ & $\begin{array}{l}\text { Sample } \\
\text { code }\end{array}$ & $\begin{array}{l}\text { Station } \\
\text { (ft) }\end{array}$ & $\begin{array}{c}\text { 16th } \\
\text { Percen- } \\
\text { tile } \\
(\mathrm{mm})\end{array}$ & $\begin{array}{c}\text { 50th } \\
\text { Percen- } \\
\text { tile } \\
(\mathbf{m m})\end{array}$ & $\begin{array}{c}\text { 84th } \\
\text { Percen- } \\
\text { tile } \\
(\mathbf{m m})\end{array}$ & $\begin{array}{c}\text { Maximum } \\
\text { particle } \\
\text { size } \\
(\mathrm{mm})\end{array}$ & $\begin{array}{l}\text { Critical } \\
\text { shear } \\
\text { with } \\
\text { Shields } \\
\text { param- } \\
\text { eter } \\
0.030 \\
\left(\mathrm{lb} / \mathrm{ft}^{2}\right)\end{array}$ & $\begin{array}{l}\text { Critical } \\
\text { shear } \\
\text { with } \\
\text { Shields } \\
\text { param- } \\
\text { eter } \\
0.045 \\
\left(\mathrm{lb}^{2} \mathrm{ft}^{2}\right)\end{array}$ & Remarks \\
\hline $\mathrm{F} 2$ & 1994 & RBank & 85 & 43 & 165 & 500 & 1,000 & 1.67 & 2.51 & $\begin{array}{l}\text { DF-2 deposit near } \\
\text { distal fan margin. }\end{array}$ \\
\hline $\mathrm{F} 1$ & 1994 & RBank & 78 & 43 & 165 & 500 & 1,000 & 1.67 & 2.51 & $\begin{array}{l}\text { DF-2 deposit near } \\
\text { distal fan margin. }\end{array}$ \\
\hline $\mathrm{H} 1$ & 1994 & RBank & 90 & 13 & 50 & 174 & 500 & 0.51 & 0.76 & $\begin{array}{l}\text { DF-3 deposit near } \\
\text { distal fan margin. }\end{array}$ \\
\hline H1 & 1994 & Fan & 105 & 11 & 33 & 109 & 320 & 0.33 & 0.50 & DF-3 deposit on fan. \\
\hline $\mathrm{H} 2$ & 1994 & RBldBar & 181 & 79 & 320 & 450 & 650 & 3.24 & 4.87 & $\begin{array}{l}\text { Reworked boulders } \\
\text { from debris fan. }\end{array}$ \\
\hline G1 & 1994 & XChan & lc & 11 & 64 & 168 & 600 & 0.65 & 0.97 & $\begin{array}{l}\text { Sampled from } \\
\text { station } 52 \text { to } 210 \text {. }\end{array}$ \\
\hline G1 & 1994 & LBldBar & 45 & 2 & 100 & 250 & 1,050 & 1.01 & 1.52 & $\begin{array}{l}\text { Sand covers boulders } \\
\text { many places. }\end{array}$ \\
\hline G1 & 1994 & LGvlBar & 79 & 16 & 36 & 76 & 120 & 0.36 & 0.55 & Well sorted gravels. \\
\hline G2 & 1994 & XChan & lc & 51 & 90 & 250 & 900 & 0.91 & 1.37 & $\begin{array}{l}\text { Sampled from } \\
\text { station } 38 \text { to } 142 .\end{array}$ \\
\hline
\end{tabular}

approximated by the relation between boundary shear stress, flow depth, and energy gradient, given by the duBoys equation (Chow, 1959, p. 168):

$$
\tau_{\mathrm{o}}=\gamma \mathrm{DS}
$$

where $\tau_{0}$ is the mean boundary shear stress, in pounds per square foot;

$\gamma$ is the specific weight of water $(62.4$ pounds per cubic foot);

$\mathrm{D}$ is the mean flow depth, in feet; and

$\mathrm{S}$ is the energy gradient, in foot per foot, for a specific discharge.

Assumptions for using equation 1 are (1) the channel cross section has a regular, or trapezoidal, shape and width at least 10 times greater than its depth, (2) streamflow is steady (there is a continuity of discharge from cross section to cross section in the reach), and (3) streamflow is uniform (velocity is constant in both magnitude and direction through the reach). Application of equation 1 is inappropriate in channel sections where there is a strong lateral variation in acceleration or where abrupt, local changes in streambed gradient occur. Cross sections in this study were not trapezoidal, although all had single-thread channels at less than flood discharges; all had width at least 20 times mean flow depth, and many were approximately symmetrical at less than flood discharges. Streamflow in the Warner Point and Red Rock Canyon study reaches was assumed to be steady; there were no significant local inflows to either reach, and infiltration losses were assumed to be insignificant.

Most natural streams do not completely satisfy the assumptions for equation 1, and the boundary shear stress associated with any specific discharge is 
Table 5. Modeled hydraulic geometry of Warner Point study reach cross sections

[Water surface, energy gradient, channel area, and channel top width from HEC-2 model; $\mathrm{ft}^{3} / \mathrm{s}$, cubic foot per second; $\mathrm{ft}$, foot; $\mathrm{ft} / \mathrm{ft}$, foot per foot; $\mathrm{ft}^{2}$, square foot; $\mathrm{ft} / \mathrm{s}$, foot per second; lb/ft ${ }^{2}$, pound per square foot]

\begin{tabular}{|c|c|c|c|c|c|c|c|}
\hline $\begin{array}{c}\text { Reference } \\
\text { discharge } \\
\left(\mathrm{ft}^{3} / \mathrm{s}\right)\end{array}$ & $\begin{array}{l}\text { Water- } \\
\text { surface } \\
\text { elevation } \\
\text { (ft) }\end{array}$ & $\begin{array}{c}\text { Energy } \\
\text { gradient } \\
(\mathrm{ft} / \mathrm{ft})\end{array}$ & $\begin{array}{c}\text { Channel area } \\
\left(\mathrm{ft}^{2}\right)\end{array}$ & $\begin{array}{l}\text { Channel } \\
\text { top width } \\
\text { (ft)) }\end{array}$ & $\begin{array}{c}\text { Mean flow } \\
\text { depth (ft) }\end{array}$ & $\begin{array}{l}\text { Mean flow } \\
\text { velocity } \\
\text { (ft/s) }\end{array}$ & $\begin{array}{c}\text { Mean bed } \\
\text { shear } \\
\left(\mathrm{lb} / \mathrm{ft}^{2}\right)\end{array}$ \\
\hline \multicolumn{8}{|c|}{ Cross Section V1 } \\
\hline 2,000 & 516.13 & 0.0074 & 474.16 & 172.08 & 2.76 & 4.22 & 1.27 \\
\hline 2,250 & 516.38 & 0.0073 & 515.64 & 173.48 & 2.97 & 4.36 & 1.35 \\
\hline 3,000 & 517.06 & 0.0071 & 629.70 & 177.18 & 3.55 & 4.76 & 1.57 \\
\hline 4,000 & 517.85 & 0.0068 & 766.99 & 181.53 & 4.23 & 5.22 & 1.79 \\
\hline 5,000 & 518.56 & 0.0066 & 891.10 & 185.37 & 4.81 & 5.61 & 1.98 \\
\hline 6,000 & 519.20 & 0.0063 & $1,007.46$ & 188.90 & 5.33 & 5.96 & 2.10 \\
\hline 7,000 & 519.79 & 0.0060 & $1,122.26$ & 194.52 & 5.77 & 6.24 & 2.16 \\
\hline 8,000 & 520.34 & 0.0058 & $1,486.43$ & 295.65 & 5.03 & 5.38 & 1.82 \\
\hline 9,000 & 520.87 & 0.0055 & $1,644.28$ & 312.93 & 5.25 & 5.47 & 1.80 \\
\hline 9,500 & 521.12 & 0.0054 & $1,724.30$ & 321.44 & 5.36 & 5.51 & 1.81 \\
\hline 10,000 & 521.36 & 0.0052 & $1,804.31$ & 329.94 & 5.47 & 5.54 & 1.77 \\
\hline 11,000 & 521.84 & 0.0050 & $1,975.69$ & 354.63 & 5.57 & 5.57 & 1.74 \\
\hline 15,000 & 523.56 & 0.0040 & $2,648.91$ & 361.25 & 7.33 & 5.66 & 1.83 \\
\hline 20,000 & 525.43 & 0.0029 & $3,453.61$ & 368.12 & 9.38 & 5.79 & 1.70 \\
\hline \multicolumn{8}{|c|}{ Cross Section V2 } \\
\hline 2,000 & 522.31 & 0.0046 & 347.26 & 93.30 & 3.72 & 5.76 & 1.07 \\
\hline 2,250 & 522.58 & 0.0046 & 415.46 & 98.14 & 4.23 & 5.42 & 1.22 \\
\hline 3,000 & 523.30 & 0.0044 & 446.48 & 100.26 & 4.45 & 6.72 & 1.22 \\
\hline 4,000 & 524.14 & 0.0043 & 664.06 & 181.75 & 3.65 & 6.02 & 0.98 \\
\hline 5,000 & 524.88 & 0.0041 & 789.65 & 191.86 & 4.12 & 6.33 & 1.05 \\
\hline 6,000 & 525.56 & 0.0040 & 915.89 & 202.75 & 4.52 & 6.55 & 1.13 \\
\hline 7,000 & 526.18 & 0.0038 & $1,040.40$ & 212.45 & 4.90 & 6.73 & 1.16 \\
\hline 8,000 & 526.77 & 0.0037 & $1,172.21$ & 228.82 & 5.12 & 6.82 & 1.18 \\
\hline 9,000 & 527.32 & 0.0035 & $1,298.52$ & 232.26 & 5.59 & 6.93 & 1.22 \\
\hline 9,500 & 527.58 & 0.0035 & $1,361.52$ & 233.94 & 5.82 & 6.98 & 1.27 \\
\hline 10,000 & 527.84 & 0.0034 & $1,424.23$ & 235.62 & 6.04 & 7.02 & 1.28 \\
\hline 11,000 & 528.34 & 0.0033 & $1,550.58$ & 238.87 & 6.49 & 7.09 & 1.34 \\
\hline 15,000 & 530.15 & 0.0029 & $2,023.84$ & 250.26 & 8.09 & 7.41 & 1.46 \\
\hline 20,000 & 532.11 & 0.0025 & $2,573.10$ & 258.94 & 9.94 & 7.77 & 1.55 \\
\hline
\end{tabular}


Table 5. Modeled hydraulic geometry of Warner Point study reach cross sections-Continued

[Water surface, energy gradient, channel area, and channel top width from HEC-2 model; $\mathrm{ft}^{3} / \mathrm{s}$, cubic foot per second; $\mathrm{ft}$, foot; $\mathrm{ft} / \mathrm{ft}$, foot per foot; $\mathrm{ft}^{2}$, square foot; $\mathrm{ft} / \mathrm{s}$, foot per second; $\mathrm{lb} / \mathrm{ft}^{2}$, pound per square foot]

\begin{tabular}{|c|c|c|c|c|c|c|c|}
\hline $\begin{array}{c}\text { Reference } \\
\text { discharge } \\
\left(\mathrm{ft}^{3} / \mathrm{s}\right)\end{array}$ & $\begin{array}{c}\text { Water- } \\
\text { surface } \\
\text { elevation } \\
\text { (ft) }\end{array}$ & $\begin{array}{c}\text { Energy } \\
\text { gradient } \\
(\mathrm{ft} / \mathrm{ft})\end{array}$ & $\begin{array}{c}\text { Channel area } \\
\left(\mathrm{ft}^{2}\right)\end{array}$ & $\begin{array}{l}\text { Channel } \\
\text { top width } \\
\text { (ft)) }\end{array}$ & $\begin{array}{c}\text { Mean flow } \\
\text { depth (ft) }\end{array}$ & $\begin{array}{c}\text { Mean flow } \\
\text { velocity } \\
\text { (ft/s) }\end{array}$ & $\begin{array}{c}\text { Mean bed } \\
\text { shear } \\
\left(\mathrm{lb} / \mathrm{ft}^{2}\right)\end{array}$ \\
\hline \multicolumn{8}{|c|}{ Cross Section H60 } \\
\hline 2,000 & 522.98 & 0.0036 & 414.63 & 125.80 & 3.30 & 4.82 & 0.74 \\
\hline 2,250 & 523.24 & 0.0035 & 427.98 & 127.34 & 3.36 & 5.26 & 0.73 \\
\hline 3,000 & 523.97 & 0.0032 & 561.26 & 157.42 & 3.57 & 5.35 & 0.71 \\
\hline 4,000 & 524.80 & 0.0030 & 720.03 & 198.90 & 3.62 & 5.56 & 0.68 \\
\hline 5,000 & 525.54 & 0.0028 & 860.76 & 214.14 & 4.02 & 5.81 & 0.70 \\
\hline 6,000 & 526.22 & 0.0026 & $1,001.23$ & 229.52 & 4.36 & 5.99 & 0.71 \\
\hline 7,000 & 526.83 & 0.0025 & $1,141.06$ & 244.49 & 4.67 & 6.13 & 0.73 \\
\hline 8,000 & 527.41 & 0.0024 & $1,287.87$ & 265.34 & 4.85 & 6.21 & 0.73 \\
\hline 9,000 & 527.95 & 0.0023 & $1,431.68$ & 270.52 & 5.29 & 6.29 & 0.76 \\
\hline 9,500 & 528.21 & 0.0022 & $1,503.33$ & 272.50 & 5.52 & 6.32 & 0.76 \\
\hline 10,000 & 528.47 & 0.0022 & $1,574.98$ & 274.48 & 5.74 & 6.35 & 0.79 \\
\hline 11,000 & 528.96 & 0.0021 & $1,718.19$ & 278.20 & 6.18 & 6.40 & 0.81 \\
\hline 15,000 & 530.72 & 0.0018 & $2,276.19$ & 304.61 & 7.47 & 6.59 & 0.84 \\
\hline 20,000 & 532.64 & 0.0016 & $2,935.08$ & 307.16 & 9.56 & 6.81 & 0.95 \\
\hline \multicolumn{8}{|c|}{ Cross Section H3 } \\
\hline 2,000 & 525.67 & 0.0033 & 586.17 & 232.60 & 2.52 & 3.41 & 0.52 \\
\hline 2,250 & 525.86 & 0.0034 & 639.45 & 236.66 & 2.70 & 3.52 & 0.57 \\
\hline 3,000 & 526.39 & 0.0034 & 732.22 & 240.74 & 3.04 & 4.10 & 0.65 \\
\hline 4,000 & 527.03 & 0.0035 & 882.05 & 243.53 & 3.62 & 4.53 & 0.79 \\
\hline 5,000 & 527.59 & 0.0036 & $1,013.85$ & 245.96 & 4.12 & 4.93 & 0.93 \\
\hline 6,000 & 528.12 & 0.0036 & $1,134.82$ & 248.17 & 4.57 & 5.29 & 1.03 \\
\hline 7,000 & 528.61 & 0.0036 & $1,248.88$ & 250.23 & 4.99 & 5.61 & 1.12 \\
\hline 8,000 & 529.07 & 0.0037 & $1,358.74$ & 252.20 & 5.39 & 5.89 & 1.24 \\
\hline 9,000 & 529.50 & 0.0037 & $1,468.30$ & 253.24 & 5.80 & 6.13 & 1.34 \\
\hline 9,500 & 529.71 & 0.0037 & $1,520.33$ & 253.38 & 6.00 & 6.25 & 1.39 \\
\hline 10,000 & 529.92 & 0.0037 & $1,572.36$ & 253.52 & 6.20 & 6.36 & 1.43 \\
\hline 11,000 & 530.32 & 0.0036 & $1,676.63$ & 253.80 & 6.61 & 6.56 & 1.48 \\
\hline 15,000 & 531.80 & 0.0034 & $2,079.30$ & 254.88 & 8.16 & 7.21 & 1.73 \\
\hline 20,000 & 533.43 & 0.0029 & $2,574.69$ & 258.12 & 9.97 & 7.77 & 1.81 \\
\hline
\end{tabular}


Table 5. Modeled hydraulic geometry of Warner Point study reach cross sections-Continued

[Water surface, energy gradient, channel area, and channel top width from HEC-2 model; $\mathrm{ft}^{3} / \mathrm{s}$, cubic foot per second; $\mathrm{ft}$, foot; $\mathrm{ft} / \mathrm{ft}$, foot per foot; $\mathrm{ft}^{2}$, square foot; $\mathrm{ft} / \mathrm{s}$, foot per second; $\mathrm{lb} / \mathrm{ft}^{2}$, pound per square foot]

\begin{tabular}{|c|c|c|c|c|c|c|c|}
\hline $\begin{array}{c}\text { Reference } \\
\text { discharge } \\
\left(\mathrm{ft}^{3} / \mathrm{s}\right)\end{array}$ & $\begin{array}{l}\text { Water- } \\
\text { surface } \\
\text { elevation } \\
\text { (ft) }\end{array}$ & $\begin{array}{c}\text { Energy } \\
\text { gradient } \\
(\mathrm{ft} / \mathrm{ft})\end{array}$ & $\begin{array}{c}\text { Channel area } \\
\left(\mathrm{ft}^{2}\right)\end{array}$ & $\begin{array}{l}\text { Channel } \\
\text { top width } \\
\text { (ft)) }\end{array}$ & $\begin{array}{l}\text { Mean flow } \\
\text { depth (ft) }\end{array}$ & $\begin{array}{l}\text { Mean flow } \\
\text { velocity } \\
(\mathrm{ft} / \mathrm{s})\end{array}$ & $\begin{array}{c}\text { Mean bed } \\
\text { shear } \\
\left(\mathrm{lb} / \mathrm{ft}^{2}\right)\end{array}$ \\
\hline \multicolumn{8}{|c|}{ Cross Section V3 } \\
\hline 2,000 & 525.97 & 0.0014 & 699.45 & 222.31 & 3.15 & 2.86 & 0.27 \\
\hline 2,250 & 526.17 & 0.0014 & 735.06 & 224.67 & 3.27 & 3.06 & 0.29 \\
\hline 3,000 & 526.54 & 0.0015 & 825.20 & 230.16 & 3.59 & 3.64 & 0.34 \\
\hline 4,000 & 527.36 & 0.0017 & 974.69 & 237.95 & 4.10 & 4.10 & 0.43 \\
\hline 5,000 & 527.94 & 0.0018 & $1,104.04$ & 244.50 & 4.52 & 4.53 & 0.51 \\
\hline 6,000 & 528.47 & 0.0019 & $1,226.20$ & 248.64 & 4.93 & 4.89 & 0.58 \\
\hline 7,000 & 528.97 & 0.0020 & $1,342.19$ & 252.97 & 5.31 & 5.22 & 0.66 \\
\hline 8,000 & 529.44 & 0.0021 & $1,454.88$ & 257.88 & 5.64 & 5.50 & 0.74 \\
\hline 9,000 & 529.88 & 0.0022 & $1,567.59$ & 262.41 & 5.97 & 5.74 & 0.82 \\
\hline 9,500 & 530.09 & 0.0022 & $1,622.03$ & 264.33 & 6.14 & 5.86 & 0.84 \\
\hline 10,000 & 530.30 & 0.0022 & $1,676.47$ & 266.25 & 6.30 & 5.96 & 0.86 \\
\hline 11,000 & 530.70 & 0.0022 & $1,786.62$ & 270.08 & 6.62 & 6.16 & 0.91 \\
\hline 15,000 & 532.17 & 0.0022 & $2,218.27$ & 273.46 & 8.11 & 6.76 & 1.11 \\
\hline 20,000 & 533.79 & 0.0019 & $2,750.42$ & 275.69 & 9.98 & 7.27 & 1.18 \\
\hline \multicolumn{8}{|c|}{ Cross Section V4 } \\
\hline 2,000 & 526.48 & 0.0026 & 512.31 & 188.02 & 2.72 & 3.90 & 0.44 \\
\hline 2,250 & 526.69 & 0.0026 & 551.66 & 191.40 & 2.88 & 4.08 & 0.47 \\
\hline 3,000 & 527.26 & 0.0026 & 580.86 & 194.75 & 2.98 & 5.16 & 0.48 \\
\hline 4,000 & 527.93 & 0.0027 & 717.28 & 239.58 & 2.99 & 5.58 & 0.50 \\
\hline 5,000 & 528.52 & 0.0027 & 854.27 & 247.75 & 3.45 & 5.85 & 0.58 \\
\hline 6,000 & 529.05 & 0.0027 & 983.85 & 255.66 & 3.85 & 6.10 & 0.65 \\
\hline 7,000 & 529.55 & 0.0027 & $1,108.22$ & 264.56 & 4.19 & 6.32 & 0.71 \\
\hline 8,000 & 530.01 & 0.0027 & $1,228.60$ & 266.96 & 4.60 & 6.51 & 0.78 \\
\hline 9,000 & 530.45 & 0.0027 & $1,345.87$ & 268.81 & 5.01 & 6.69 & 0.84 \\
\hline 9,500 & 530.66 & 0.0027 & $1,401.98$ & 269.68 & 5.20 & 6.78 & 0.88 \\
\hline 10,000 & 530.86 & 0.0027 & $1,458.08$ & 270.56 & 5.39 & $6 . \dot{86}$ & 0.91 \\
\hline 11,000 & 531.25 & 0.0027 & $1,569.17$ & 272.28 & 5.76 & 7.01 & 0.97 \\
\hline 15,000 & 532.68 & 0.0025 & $1,998.77$ & 278.85 & 7.17 & 7.50 & 1.12 \\
\hline 20,000 & 534.23 & 0.0021 & $2,535.83$ & 291.06 & 8.71 & 7.89 & 1.14 \\
\hline
\end{tabular}


Table 5. Modeled hydraulic geometry of Warner Point study reach cross sections-Continued

[Water surface, energy gradient, channel area, and channel top width from HEC-2 model; $\mathrm{ft}^{3} / \mathrm{s}$, cubic foot per second; ft, foot; $\mathrm{ft} / \mathrm{ft}$, foot per foot; $\mathrm{ft}^{2}$, square foot; $\mathrm{ft} / \mathrm{s}$, foot per second; $\mathrm{lb} / \mathrm{ft}^{2}$, pound per square foot]

\begin{tabular}{|c|c|c|c|c|c|c|c|}
\hline $\begin{array}{c}\text { Reference } \\
\text { discharge } \\
\left(\mathrm{ft}^{3} / \mathrm{s}\right)\end{array}$ & $\begin{array}{c}\text { Water- } \\
\text { surface } \\
\text { elevation } \\
\text { (ft) }\end{array}$ & $\begin{array}{c}\text { Energy } \\
\text { gradient } \\
\text { (ft/ft) }\end{array}$ & $\begin{array}{c}\text { Channel area } \\
\left(\mathrm{ft}^{2}\right)\end{array}$ & $\begin{array}{l}\text { Channel } \\
\text { top width } \\
\text { (ft)) }\end{array}$ & $\begin{array}{l}\text { Mean flow } \\
\text { depth (ft) }\end{array}$ & $\begin{array}{c}\text { Mean flow } \\
\text { velocity } \\
\text { (ft/s) }\end{array}$ & $\begin{array}{c}\text { Mean bed } \\
\text { shear } \\
\left(\mathbf{l b} / \mathrm{ft}^{2}\right)\end{array}$ \\
\hline \multicolumn{8}{|c|}{ Cross Section V5 } \\
\hline 2,000 & 542.55 & 0.0073 & 510.88 & 170.64 & 2.99 & 3.91 & 1.36 \\
\hline 2,250 & 542.74 & 0.0073 & 524.28 & 174.51 & 3.00 & 4.29 & 1.37 \\
\hline 3,000 & 543.27 & 0.0074 & 598.94 & 198.05 & 3.02 & 5.01 & 1.40 \\
\hline 4,000 & 543.89 & 0.0075 & 734.25 & 235.42 & 3.12 & 5.45 & 1.46 \\
\hline 5,000 & 544.44 & 0.0075 & 871.46 & 274.07 & 3.18 & 5.74 & 1.49 \\
\hline 6,000 & 544.93 & 0.0076 & $1,009.07$ & 303.00 & 3.33 & 5.95 & 1.58 \\
\hline 7,000 & 545.38 & 0.0076 & $1,143.82$ & 322.46 & 3.55 & 6.12 & 1.68 \\
\hline 8,000 & 545.81 & 0.0076 & $1,279.94$ & 333.86 & 3.83 & 6.25 & 1.82 \\
\hline 9,000 & 546.21 & 0.0076 & $1,409.90$ & 335.62 & 4.20 & 6.38 & 1.99 \\
\hline 9,500 & 546.40 & 0.0075 & $1,474.48$ & 336.50 & 4.38 & 6.44 & 2.05 \\
\hline 10,000 & 546.58 & 0.0075 & $1,539.06$ & 337.37 & 4.56 & 6.50 & 2.13 \\
\hline 11,000 & 546.94 & 0.0075 & $1,664.72$ & 339.06 & 4.91 & 6.61 & 2.30 \\
\hline 15,000 & 548.25 & 0.0069 & $2,142.43$ & 345.41 & 6.20 & 7.00 & 2.67 \\
\hline 20,000 & 549.65 & 0.0057 & $2,695.69$ & 351.53 & 7.67 & 7.42 & 2.73 \\
\hline \multicolumn{8}{|c|}{ Cross Section H9 } \\
\hline 2,000 & 543.14 & 0.0039 & 584.92 & 156.47 & 3.74 & 3.42 & 0.91 \\
\hline 2,250 & 543.34 & 0.0040 & 626.60 & 186.35 & 3.36 & 3.59 & 0.84 \\
\hline 3,000 & 543.90 & 0.0042 & 713.86 & 213.72 & 3.34 & 4.20 & 0.88 \\
\hline 4,000 & 544.54 & 0.0045 & 861.83 & 223.48 & 3.86 & 4.64 & 1.08 \\
\hline 5,000 & 545.09 & 0.0048 & 995.00 & 256.56 & 3.88 & 5.03 & 1.16 \\
\hline 6,000 & 545.60 & 0.0050 & $1,131.99$ & 291.01 & 3.89 & 5.30 & 1.21 \\
\hline 7,000 & 546.06 & 0.0053 & $1,260.01$ & 294.92 & 4.27 & 5.56 & 1.41 \\
\hline 8,000 & 546.49 & 0.0054 & $1,378.45$ & 296.49 & 4.65 & 5.80 & 1.57 \\
\hline 9,000 & 546.89 & 0.0056 & $1,488.91$ & 297.95 & 5.00 & 6.04 & 1.75 \\
\hline 9,500 & 547.08 & 0.0057 & $1,542.39$ & 298.65 & 5.16 & 6.16 & 1.84 \\
\hline 10,000 & 547.27 & 0.0058 & $1,595.87$ & 299.35 & 5.33 & 6.27 & 1.93 \\
\hline 11,000 & 547.63 & 0.0059 & $1,699.04$ & 300.70 & 5.65 & 6.47 & 2.08 \\
\hline 15,000 & 548.92 & 0.0061 & $2,087.78$ & 305.72 & 6.83 & 7.18 & 2.60 \\
\hline 20,000 & 550.30 & 0.0058 & $2,553.72$ & 311.63 & 8.19 & 7.83 & 2.97 \\
\hline
\end{tabular}


Table 6. Modeled hydraulic geometry of Red Rock Canyon study reach cross sections

[Water surface, energy gradient, channel area, and channel top width from HEC-2 model; $\mathrm{ft}^{3} / \mathrm{s}$, cubic foot per second; ft, foot; $\mathrm{ft} / \mathrm{ft}$, foot per foot; $\mathrm{ft}^{2}$, square foot; $\mathrm{ft} / \mathrm{s}$, foot per second; $\mathrm{lb} / \mathrm{ft}^{2}$, pound per square foot]

\begin{tabular}{|c|c|c|c|c|c|c|c|}
\hline $\begin{array}{c}\text { Reference } \\
\text { discharge } \\
\left(\mathrm{ft}^{3} / \mathrm{s}\right)\end{array}$ & $\begin{array}{c}\text { Water } \\
\text { surface } \\
\text { elevation } \\
\text { (ft) }\end{array}$ & $\begin{array}{c}\text { Energy } \\
\text { gradient } \\
(\mathrm{ft} / \mathrm{tt})\end{array}$ & $\begin{array}{c}\text { Channel area } \\
\left(\mathrm{ft}^{2}\right)\end{array}$ & $\begin{array}{l}\text { Channel } \\
\text { top width } \\
\text { (ft) }\end{array}$ & $\begin{array}{l}\text { Mean flow } \\
\text { depth } \\
\text { (ft) }\end{array}$ & $\begin{array}{l}\text { Mean flow } \\
\text { velocity } \\
(\mathrm{ft} / \mathrm{s})\end{array}$ & $\begin{array}{l}\text { Mean bed } \\
\text { shear } \\
\left(\mathrm{lb} / \mathrm{ft}^{2}\right)\end{array}$ \\
\hline \multicolumn{8}{|c|}{ Cross Section F2 } \\
\hline 2,000 & $4,993.45$ & 0.00973 & 328.05 & 69.60 & 4.71 & 6.10 & 2.86 \\
\hline 2,200 & $4,993.67$ & 0.01019 & 343.94 & 70.63 & 4.87 & 6.40 & 3.10 \\
\hline 3,000 & $4,994.49$ & 0.01177 & 402.90 & 74.27 & 5.42 & 7.45 & 3.98 \\
\hline 4,000 & $4,995.33$ & 0.01347 & 466.92 & 78.17 & 5.97 & 8.57 & 5.02 \\
\hline 5,000 & $4,996.04$ & 0.01503 & 523.95 & 82.04 & 6.39 & 9.54 & 5.99 \\
\hline 6,000 & $4,996.62$ & 0.01675 & 572.49 & 85.20 & 6.72 & 10.48 & 7.02 \\
\hline 7,000 & $4,997.14$ & 0.01836 & 617.43 & 87.40 & 7.06 & 11.34 & 8.09 \\
\hline 8,000 & $4,997.60$ & 0.01995 & 658.15 & 88.68 & 7.42 & 12.16 & 9.24 \\
\hline 9,000 & $4,998.02$ & 0.02135 & 695.14 & 89.79 & 7.74 & 12.95 & 10.31 \\
\hline 9,500 & $4,998.22$ & 0.02210 & 712.99 & 90.32 & 7.89 & 13.32 & 10.89 \\
\hline 10,000 & $4,998.41$ & 0.02282 & 730.51 & 90.84 & 8.04 & 13.69 & 11.45 \\
\hline 11,000 & $4,998.77$ & 0.02432 & 762.97 & 91.79 & 8.31 & 14.42 & 12.62 \\
\hline 15,000 & $4,999.90$ & 0.03098 & 868.75 & 94.81 & 9.16 & 17.27 & 17.71 \\
\hline 20,000 & $5,002.44$ & 0.02646 & $1,118.42$ & 102.26 & 10.94 & 17.88 & 18.06 \\
\hline \multicolumn{8}{|c|}{ Cross Section F1 } \\
\hline 2,000 & $4,994.40$ & 0.0144 & 209.60 & 53.82 & 3.89 & 9.54 & 3.51 \\
\hline 2,200 & $4,994.63$ & 0.0148 & 222.47 & 55.54 & 4.01 & 9.89 & 3.69 \\
\hline 3,000 & $4,995.48$ & 0.0158 & 271.83 & 61.67 & 4.41 & 11.04 & 4.33 \\
\hline 4,000 & $4,996.42$ & 0.0162 & 333.12 & 68.53 & 4.86 & 12.01 & 4.91 \\
\hline 5,000 & $4,997.52$ & 0.0143 & 413.24 & 78.18 & 5.29 & 12.10 & 4.71 \\
\hline 6,000 & $4,998.39$ & 0.0135 & 487.74 & 90.01 & 5.42 & 12.30 & 4.58 \\
\hline 7,000 & $4,999.13$ & 0.0132 & 556.13 & 93.55 & 5.94 & 12.59 & 4.90 \\
\hline 8,000 & $4,999.93$ & 0.0123 & 631.20 & 95.38 & 6.62 & 12.67 & 5.10 \\
\hline 9,000 & $5,000.45$ & 0.0128 & 687.29 & 107.01 & 6.42 & 13.09 & 5.13 \\
\hline 9,500 & $5,001.10$ & 0.0111 & 759.94 & 113.78 & 6.68 & 12.50 & 4.65 \\
\hline 10,000 & $5,001.64$ & 0.0102 & 821.80 & 119.12 & 6.90 & 12.17 & 4.39 \\
\hline 11,000 & $5,003.07$ & 0.0075 & $1,003.05$ & 133.56 & 7.51 & 10.97 & 3.53 \\
\hline 15,000 & $5,005.81$ & 0.0060 & $1,403.42$ & 153.52 & 9.14 & 10.69 & 3.39 \\
\hline 20,000 & $5,008.33$ & 0.0053 & $1,792.93$ & 155.00 & 11.57 & 11.15 & 3.82 \\
\hline
\end{tabular}


Table 6. Modeled hydraulic geometry of Red Rock Canyon study reach cross sections—Continued

[Water surface, energy gradient, channel area, and channel top width from HEC-2 model; $\mathrm{ft}^{3} / \mathrm{s}$, cubic foot per second; ft, foot; $\mathrm{ft} / \mathrm{ft}$, foot per foot; $\mathrm{ft}^{2}$, square foot; $\mathrm{ft} / \mathrm{s}$, foot per second; $\mathrm{lb} / \mathrm{ft}^{2}$, pound per square foot]

\begin{tabular}{|c|c|c|c|c|c|c|c|}
\hline $\begin{array}{c}\text { Reference } \\
\text { discharge } \\
\left(\mathrm{ft}^{3} / \mathrm{s}\right)\end{array}$ & $\begin{array}{c}\text { Water } \\
\text { surface } \\
\text { elevation } \\
\text { (ft) }\end{array}$ & $\begin{array}{c}\text { Energy } \\
\text { gradient } \\
\text { (ft/tt) }\end{array}$ & $\begin{array}{c}\text { Channel area } \\
\left(\mathrm{ft}^{2}\right)\end{array}$ & $\begin{array}{l}\text { Channel } \\
\text { top width } \\
\text { (ft) }\end{array}$ & $\begin{array}{l}\text { Mean flow } \\
\text { depth } \\
\text { (ft) }\end{array}$ & $\begin{array}{l}\text { Mean flow } \\
\text { velocity } \\
(\mathrm{ft} / \mathrm{s})\end{array}$ & $\begin{array}{l}\text { Mean bed } \\
\text { shear } \\
\left(\mid \mathrm{b} / \mathrm{ft}^{2}\right)\end{array}$ \\
\hline \multicolumn{8}{|c|}{ Cross Section H1 } \\
\hline 2,000 & $4,995.81$ & 0.0023 & 366.93 & 81.29 & 4.51 & 5.45 & 0.65 \\
\hline 2,200 & $4,996.17$ & 0.0023 & 396.58 & 83.71 & 4.74 & 5.55 & 0.67 \\
\hline 3,000 & $4,997.48$ & 0.0020 & 520.27 & 98.80 & 5.27 & 5.77 & 0.65 \\
\hline 4,000 & $4,998.88$ & 0.0017 & 662.00 & 103.47 & 6.40 & 6.04 & 0.69 \\
\hline 5,000 & $5,000.01$ & 0.0016 & 781.03 & 111.17 & 7.03 & 6.40 & 0.72 \\
\hline 6,000 & $5,000.97$ & 0.0016 & 896.25 & 127.65 & 7.02 & 6.69 & 0.70 \\
\hline 7,000 & $5,001.84$ & 0.0016 & $1,012.80$ & 139.65 & 7.25 & 6.91 & 0.71 \\
\hline 8,000 & $5,002.61$ & 0.0015 & $1,124.78$ & 150.28 & 7.48 & 7.11 & 0.72 \\
\hline 9,000 & $5,003.40$ & 0.0015 & $1,248.44$ & 161.21 & 7.74 & 7.21 & 0.72 \\
\hline 9,500 & $5,003.73$ & 0.0015 & $1,302.48$ & 165.78 & 7.86 & 7.29 & 0.72 \\
\hline 10,000 & $5,004.08$ & 0.0015 & $1,361.22$ & 169.56 & 8.03 & 7.35 & 0.73 \\
\hline 11,000 & $5,004.91$ & 0.0014 & $1,504.38$ & 177.81 & 8.46 & 7.31 & 0.71 \\
\hline 15,000 & $5,007.38$ & 0.0012 & $1,974.52$ & 203.19 & 9.72 & 7.60 & 0.74 \\
\hline 20,000 & $5,009.89$ & 0.0011 & $2,518.79$ & 230.20 & 10.94 & 7.94 & 0.77 \\
\hline \multicolumn{8}{|c|}{ Cross Section H2 } \\
\hline 2,000 & $4,996.41$ & 0.00032 & 634.59 & 202.00 & 3.14 & 3.15 & 0.06 \\
\hline 2,200 & $4,996.79$ & 0.00029 & 715.30 & 220.77 & 3.24 & 3.08 & 0.06 \\
\hline 3,000 & $4,998.16$ & 0.00018 & $1,024.49$ & 231.46 & 4.43 & 2.93 & 0.05 \\
\hline 4,000 & $4,999.58$ & 0.00013 & $1,364.44$ & 250.86 & 5.44 & 2.93 & 0.05 \\
\hline 5,000 & $5,000.76$ & 0.00011 & $1,676.27$ & 283.22 & 5.92 & 2.98 & 0.04 \\
\hline 6,000 & $5,001.78$ & 0.00010 & $1,976.86$ & 300.81 & 6.57 & 3.04 & 0.04 \\
\hline 7,000 & $5,002.70$ & 0.00009 & $2,258.51$ & 307.65 & 7.34 & 3.10 & 0.04 \\
\hline 8,000 & $5,003.53$ & 0.00009 & $2,514.76$ & 312.07 & 8.06 & 3.18 & 0.04 \\
\hline 9,000 & $5,004.35$ & 0.00008 & $2,772.67$ & 315.47 & 8.79 & 3.25 . & 0.04 \\
\hline 9,500 & $5,004.70$ & 0.00008 & $2,884.72$ & 316.69 & 9.11 & 3.29 & 0.04 \\
\hline 10,000 & $5,005.06$ & 0.00008 & $2,999.37$ & 317.93 & 9.43 & 3.33 & 0.05 \\
\hline 11,000 & $5,005.87$ & 0.00007 & $3,257.59$ & 320.94 & 10.15 & 3.38 & 0.05 \\
\hline 15,000 & $5,008.39$ & 0.00007 & $4,079.59$ & 332.96 & 12.25 & 3.68 & 0.05 \\
\hline 20,000 & $5,010.94$ & 0.00007 & $4,945.28$ & 345.16 & 14.33 & 4.04 & 0.06 \\
\hline
\end{tabular}


Table 6. Modeled hydraulic geometry of Red Rock Canyon study reach cross sections-Continued

[Water surface, energy gradient, channel area, and channel top width from HEC-2 model; $\mathrm{ft}^{3} / \mathrm{s}$, cubic foot per second; ft, foot; $\mathrm{ft} / \mathrm{ft}$, foot per foot; $\mathrm{ft}^{2}$, square foot; $\mathrm{ft} / \mathrm{s}$, foot per second; $\mathrm{lb} / \mathrm{ft}^{2}$, pound per square foot]

\begin{tabular}{cccccccc}
\hline $\begin{array}{c}\text { Reference } \\
\text { discharge } \\
\left(\mathrm{ft}^{3} / \mathbf{s}\right)\end{array}$ & $\begin{array}{c}\text { Water } \\
\text { surface } \\
\text { elevation } \\
(\mathrm{ft})\end{array}$ & $\begin{array}{c}\text { Energy } \\
\text { gradient } \\
(\mathrm{ft} / \mathrm{ft})\end{array}$ & $\begin{array}{c}\text { Channel area } \\
\left(\mathrm{ft}^{2}\right)\end{array}$ & $\begin{array}{c}\text { Channel } \\
\text { top width } \\
(\mathrm{ft})\end{array}$ & $\begin{array}{c}\text { Mean flow } \\
\text { depth } \\
(\mathrm{ft})\end{array}$ & $\begin{array}{c}\text { Mean flow } \\
\text { velocity } \\
(\mathrm{ft} / \mathbf{s})\end{array}$ & $\begin{array}{c}\text { Mean bed } \\
\text { shear } \\
\left(\mathrm{Ib} / \mathrm{ft}^{2}\right)\end{array}$ \\
\hline
\end{tabular}

\begin{tabular}{|c|c|c|c|c|c|c|c|}
\hline \multicolumn{8}{|c|}{ Cross Section G1 } \\
\hline 2,000 & $4,996.24$ & 0.00072 & 370.51 & 133.80 & 2.77 & 5.40 & 0.12 \\
\hline 2,200 & $4,996.62$ & 0.00057 & 422.14 & 144.06 & 2.93 & 5.21 & 0.10 \\
\hline 3,000 & $4,997.90$ & 0.00026 & 625.26 & 164.86 & 3.79 & 4.80 & 0.06 \\
\hline 4,000 & $4,999.26$ & 0.00015 & 854.63 & 173.30 & 4.93 & 4.68 & 0.05 \\
\hline 5,000 & $5,000.39$ & 0.00011 & $1,054.96$ & 180.27 & 5.85 & 4.74 & 0.04 \\
\hline 6,000 & $5,001.38$ & 0.00009 & $1,239.40$ & 191.09 & 6.49 & 4.84 & 0.04 \\
\hline 7,000 & $5,002.29$ & 0.00008 & $1,414.37$ & 196.71 & 7.19 & 4.95 & 0.04 \\
\hline 8,000 & $5,003.09$ & 0.00008 & $1,574.38$ & 201.71 & 7.81 & 5.08 & 0.04 \\
\hline 9,000 & $5,003.89$ & 0.00007 & $1,738.35$ & 206.27 & 8.43 & 5.18 & 0.04 \\
\hline 9,500 & $5,004.23$ & 0.00007 & $1,809.14$ & 207.37 & 8.72 & 5.25 & 0.04 \\
\hline 10,000 & $5,004.59$ & 0.00007 & $1,882.25$ & 208.49 & 9.03 & 5.31 & 0.04 \\
\hline 11,000 & $5,005.39$ & 0.00006 & $2,050.11$ & 211.02 & 9.72 & 5.37 & 0.04 \\
\hline 15,000 & $5,007.82$ & 0.00006 & $2,572.93$ & 219.92 & 11.70 & 5.83 & 0.04 \\
\hline 20,000 & $5,010.27$ & 0.00006 & $3,125.64$ & 231.77 & 13.49 & 6.40 & 0.05 \\
\hline \multicolumn{8}{|c|}{ Cross Section G2 } \\
\hline 2,000 & $4,996.78$ & 0.00057 & 448.82 & 117.09 & 3.83 & 4.46 & 0.14 \\
\hline 2,200 & $4,997.09$ & 0.00054 & 486.52 & 120.12 & 4.05 & 4.52 & 0.14 \\
\hline 3,000 & $4,998.33$ & 0.00044 & 640.14 & 127.94 & 5.00 & 4.69 & 0.14 \\
\hline 4,000 & $4,999.68$ & 0.00038 & 820.81 & 141.36 & 5.81 & 4.87 & 0.14 \\
\hline 5,000 & $5,000.82$ & 0.00035 & 988.68 & 153.51 & 6.44 & 5.06 & 0.14 \\
\hline 6,000 & $5,001.80$ & 0.00034 & $1,143.98$ & 163.20 & 7.01 & 5.24 & 0.15 \\
\hline 7,000 & $5,002.69$ & 0.00033 & $1,293.25$ & 170.67 & 7.58 & 5.41 & 0.16 \\
\hline 8,000 & $5,003.49$ & 0.00032 & $1,431.38$ & 174.71 & 8.19 & 5.59 & 0.17 \\
\hline 9,000 & $5,004.28$ & 0.00032 & $1,578.37$ & 185.83 & 8.49 & 5.70 & 0.17 \\
\hline 9,500 & $5,004.63$ & 0.00032 & $1,642.67$ & 188.86 & 8.70 & 5.78 & 0.17 \\
\hline 10,000 & $5,004.98$ & 0.00032 & $1,709.24$ & 191.94 & 8.91 & 5.85 & 0.18 \\
\hline 11,000 & $5,005.76$ & 0.00031 & $1,862.76$ & 198.87 & 9.37 & 5.91 & 0.18 \\
\hline 15,000 & $5,008.20$ & 0.00031 & $2,374.70$ & 220.42 & 10.77 & 6.32 & 0.21 \\
\hline 20,000 & $5,010.68$ & 0.00032 & $2,945.96$ & 240.30 & 12.26 & 6.79 & 0.24 \\
\hline
\end{tabular}


nonuniformly distributed across the channel. Lateral and downstream variations in cross-section morphology and variations in energy gradient with discharge result in a wide range of boundary shear stresses and, consequently, produce variable conditions for sediment entrainment, sorting, and deposition. Point depths along each cross section were substituted for the cross-section mean flow depth in equation 1 to examine the relative effects of different discharges at a variety of locations within the study reaches. Shear stresses associated with a range of discharges from 2,000 to $20,000 \mathrm{ft}^{3} / \mathrm{s}$ were calculated at intervals on each cross section by using output from the HEC-2 and HEC-RAS models. Cross-section geometry and the variation in cross-channel shearstress distribution at three reference discharges are shown in figures 6 and 7.

\section{Sediment Entrainment}

Breakup and entrainment of the relatively coarse streambed surface, or pavement, in a gravel/cobble stream periodically is necessary to adjust or maintain channel dimensions and to entrain the underlying gravel, sand, silt, and clay (Milhous, 1982). It also appears that encroaching riparian vegetation can be temporarily eradicated when the median particle size $\left(\mathrm{d}_{50}\right)$ of sediment in alluvial banks and bars are regularly entrained (Friedman and Auble, in press). The primary objective of this study was to determine the hydraulic conditions and minimum streamflow necessary to entrain sediment $d_{50}$ of the alluvial banks and bars in selected areas of BLCA vulnerable to riparian vegetation encroachment.

The critical shear stress $\left(\tau_{c}\right)$, the shear stress at which general movement of sediment begins, has been related to sediment-size characteristics (Shields, 1936; Lane, 1955; Fahnestock, 1963; Carling, 1983; Komar, 1987; Wilcock, 1992). Elliott and Parker (1997) and J.G. Elliott and L.A. Hammack (written commun., 1999) used the Shields (1936) equation to estimate the critical shear stress for entrainment of sediment $d_{50}$ :

$$
\tau_{c}=\tau_{c}^{*}\left(\gamma_{s}-\gamma\right) d_{50}
$$

where $\tau_{\mathrm{c}}$ is the critical shear stress, in newtons per square meter; $\tau^{*}{ }_{\mathrm{c}}$ is the dimensionless critical shear stress or Shields parameter;

$\gamma_{\mathrm{s}}$ is the specific weight of sediment (assumed to be $25,990 \mathrm{~N} / \mathrm{m}^{3}$ );

$\gamma$ is the specific weight of water $\left(9,807 \mathrm{~N} / \mathrm{m}^{3}\right)$; and

$\mathrm{d}_{50}$ is the median particle size, in meters.

Critical shear stress in equation 2 (newtons per square meter) is converted to English units (pounds per square foot) by multiplying by 0.02088 .

Once $\tau_{\mathrm{c}}$ has been identified for a specific deposit, the critical discharge, the minimum streamflow required to entrain sediment $\mathrm{d}_{50}$, can be estimated by equating $\tau_{\mathrm{o}}$ with $\tau_{\mathrm{c}}$ and using the relation between shear stress and discharge at a specific cross-section location.

Wilcock (1992, p. 297) states that equation 2 and $d_{50}$ can be used to provide a minimum estimate of the shear stress necessary to initiate general movement of a mixed-size sediment based on experiments using sediments with $d_{50}$ up to about $20 \mathrm{~mm}$. Lane's (1955) data indicate that the Shields equation is applicable for sediments with a 75 th percentile $\left(d_{75}\right)$ up to about $100 \mathrm{~mm}$. When the boundary shear stress, $\tau_{\mathrm{o}}$, is compared with the critical shear stress, $\tau_{c}$, for the $d_{50}$ at various locations on the cross sections, it is possible to evaluate the sediment-entrainment potential of each discharge with respect to a particular geomorphic surface or location on a cross section (figs. 6 and 7).

The critical shear stress associated with sediment entrainment (eq. 2) is, at best, a minimum estimate of the critical discharge because only a small area of the entire surface or a few particles of the $d_{50}$ size may be entrained by the critical discharge (Lisle and others, 1993; Milhous, 1982). Wilcock and McArdell (1993) observed that complete mobilization of a size fraction, such as $\mathrm{d}_{50}$, occurred at roughly twice the shear stress necessary for incipient motion of individual particles in that size fraction.

Use of equation 2 requires an estimated or calculated dimensionless critical shear stress, or Shields parameter, $\tau^{*}$. Neill (1968) recommended a $\tau^{*}{ }_{c}$ of 0.030 for streambeds composed of coarse materials; however, other investigators have demonstrated a variable $\tau^{*}{ }_{\mathrm{c}}$ in channels with mixed-size sediments (Komar, 1987) and in channels where the bed-surface size is significantly larger than the subsurface size (Parker and others, 1982; Andrews, 1983). Powell and Ashworth (1995) found $\tau^{*}$ c varied with the strength of bed-surface structure. Tightly structured beds (those 


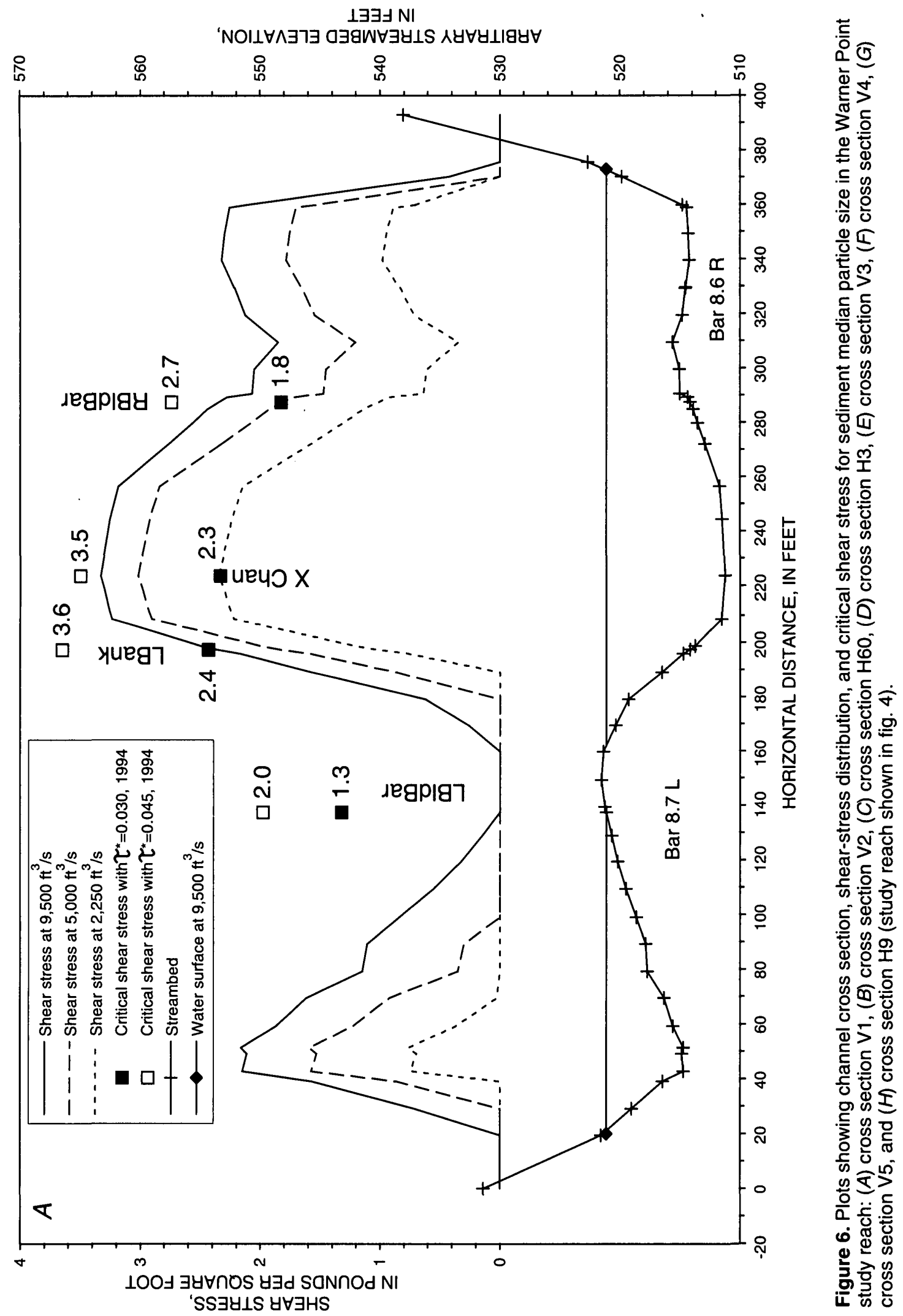




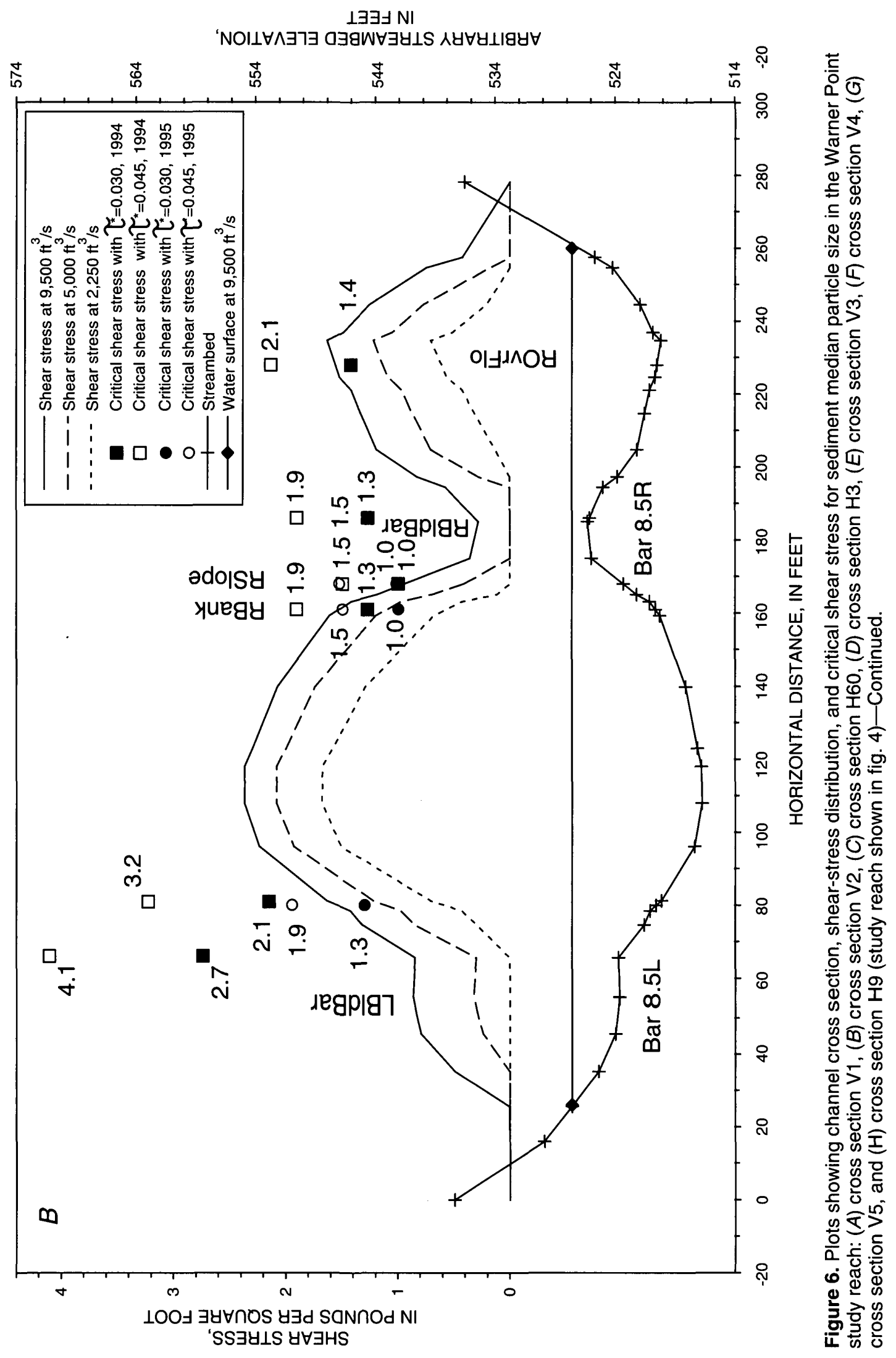




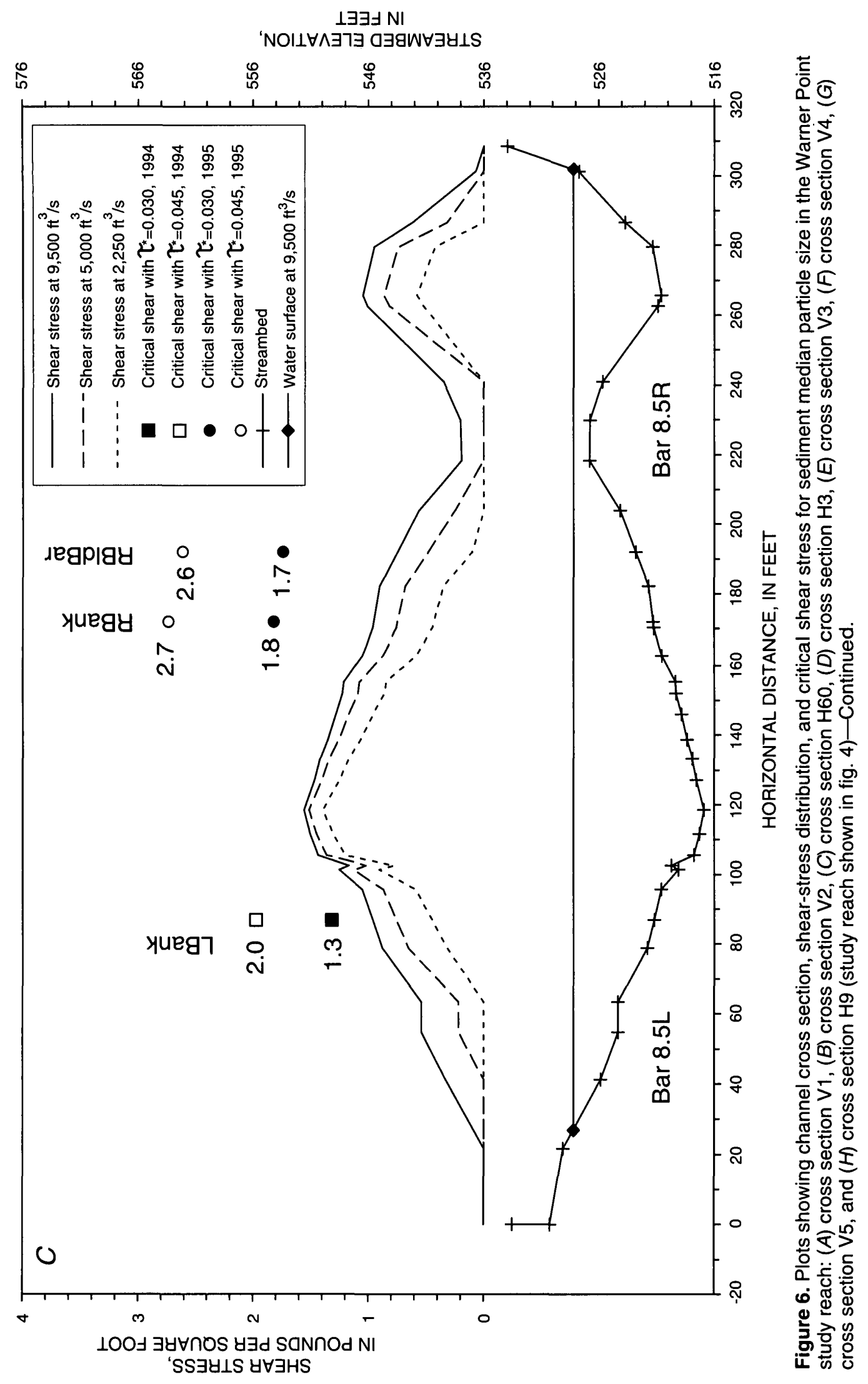




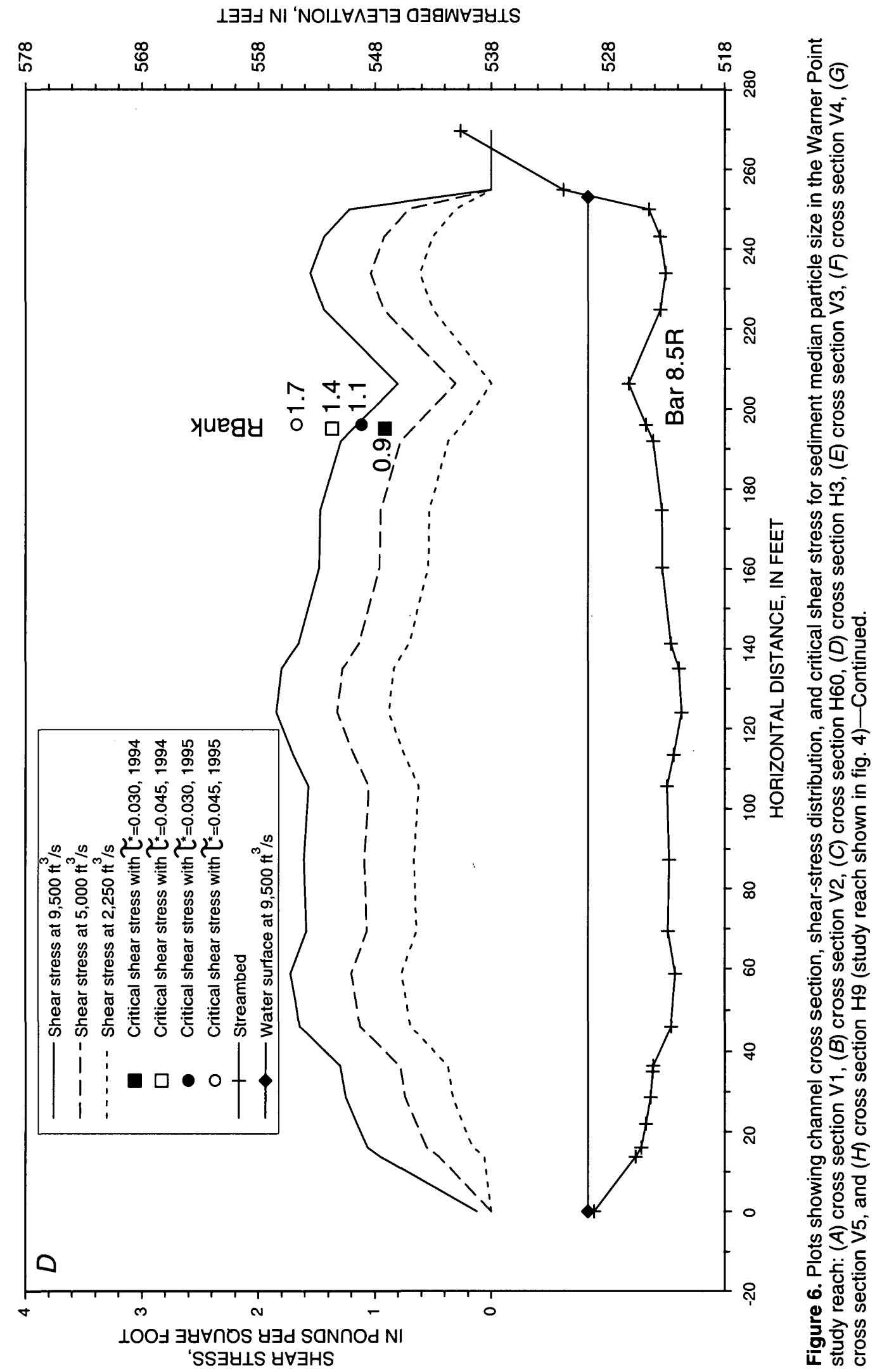




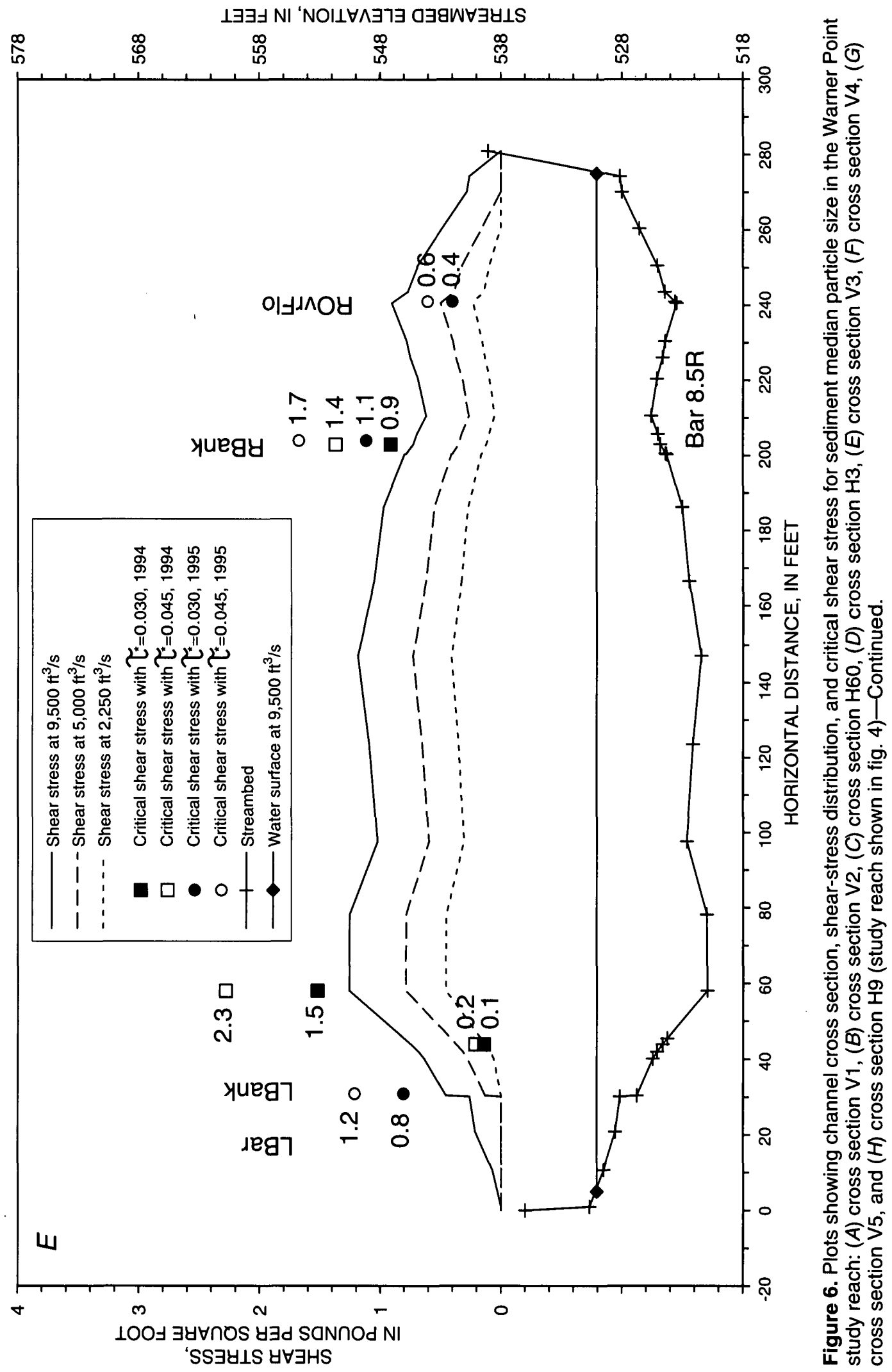




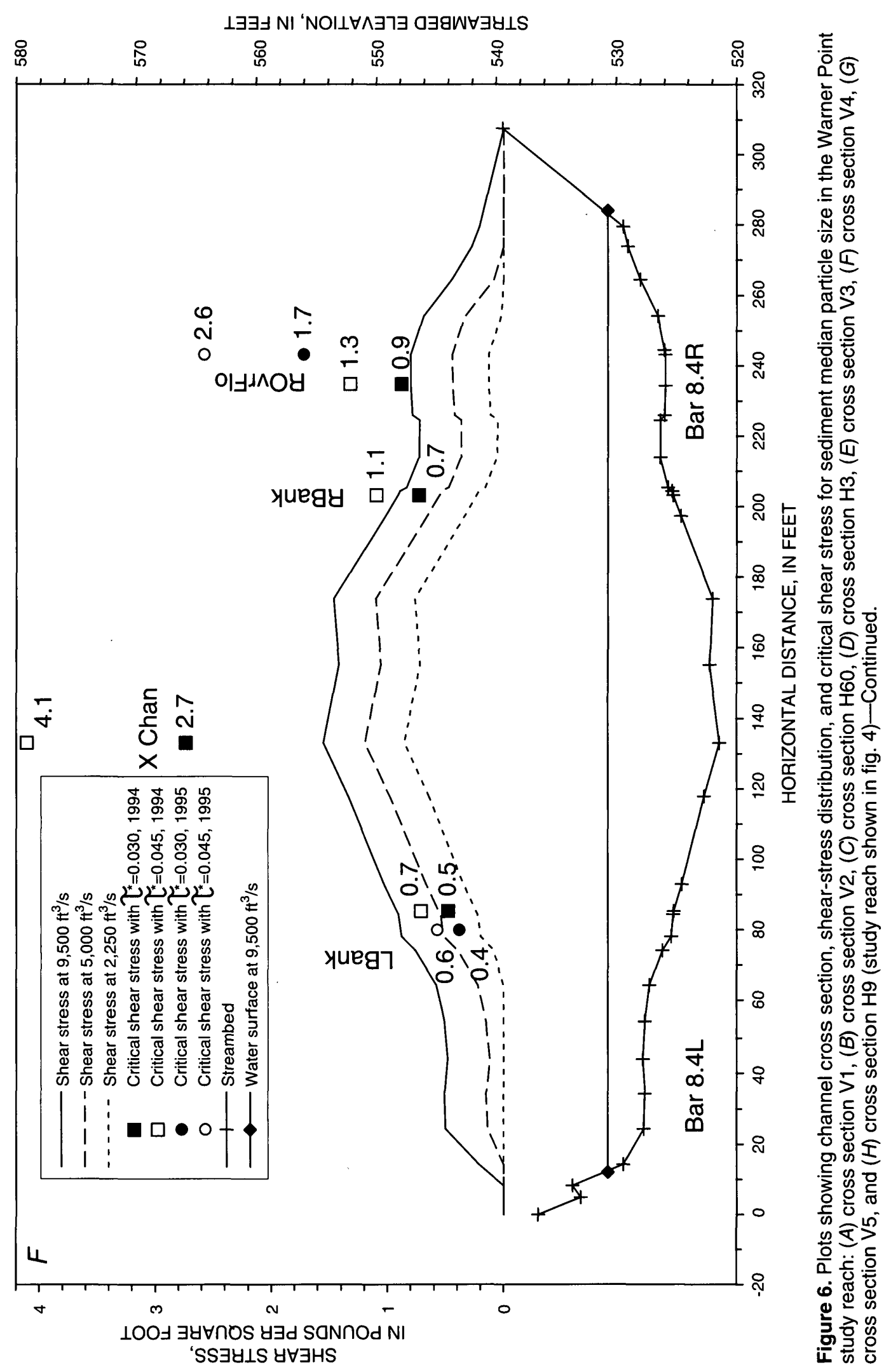




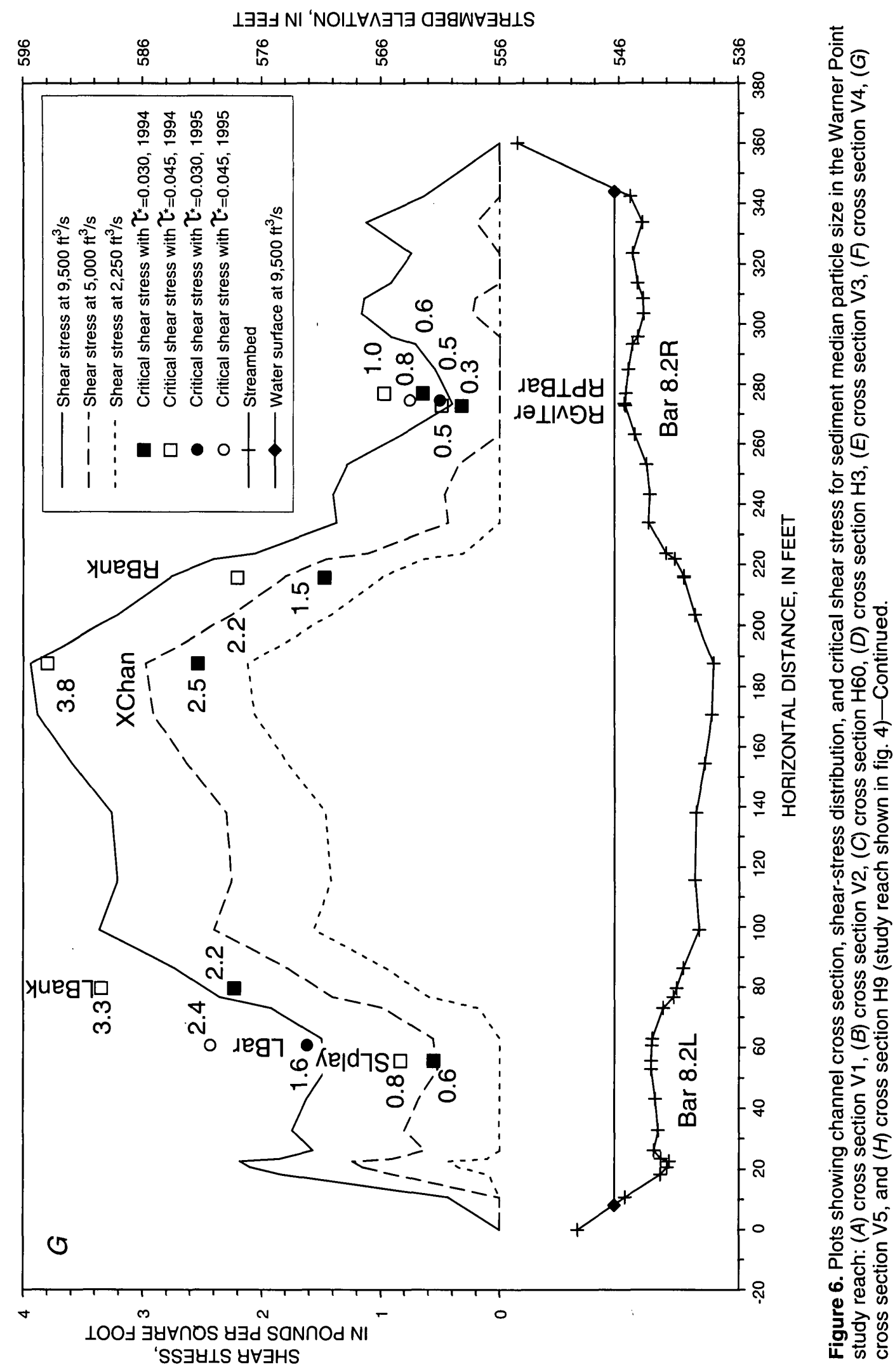




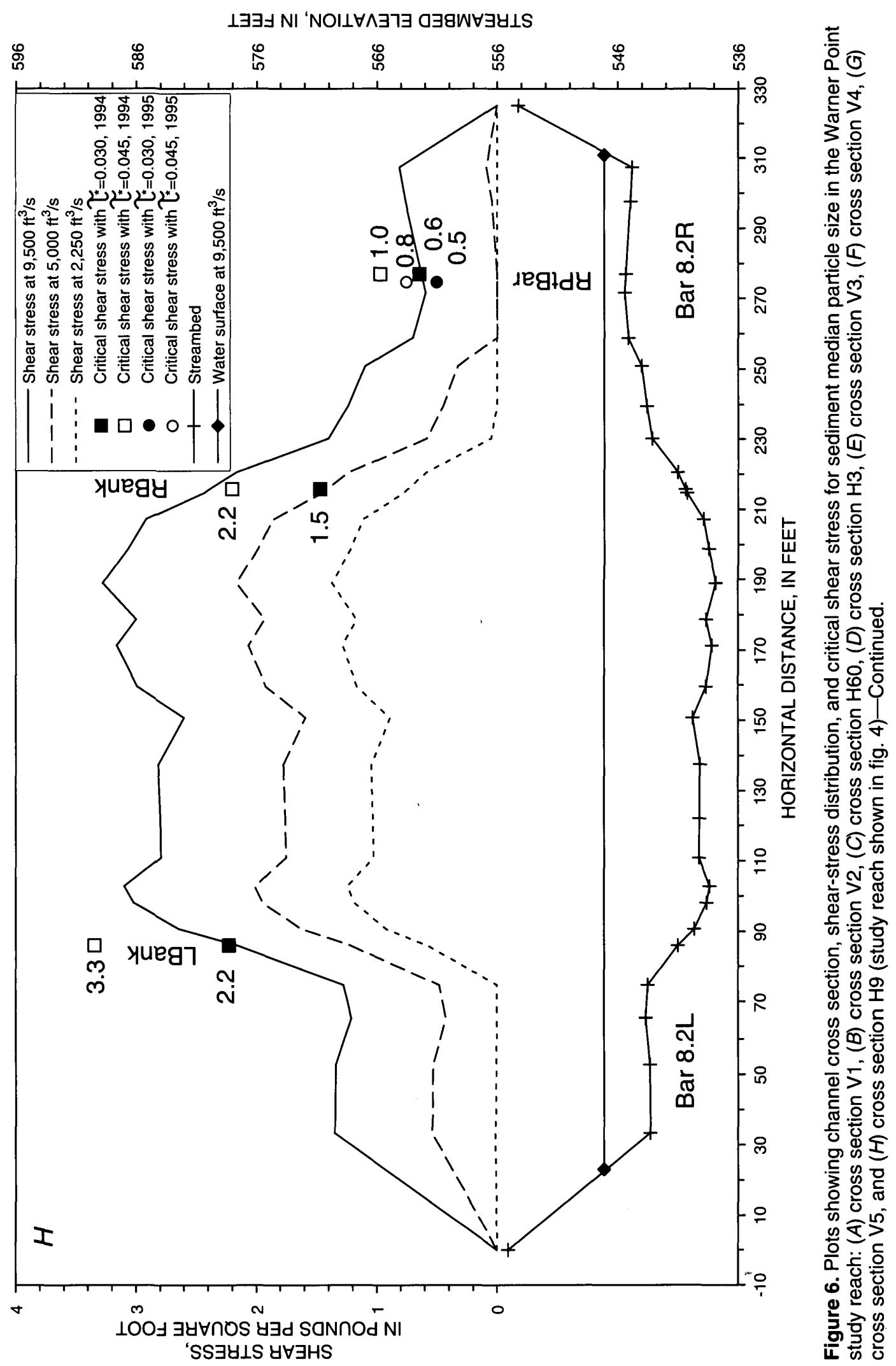




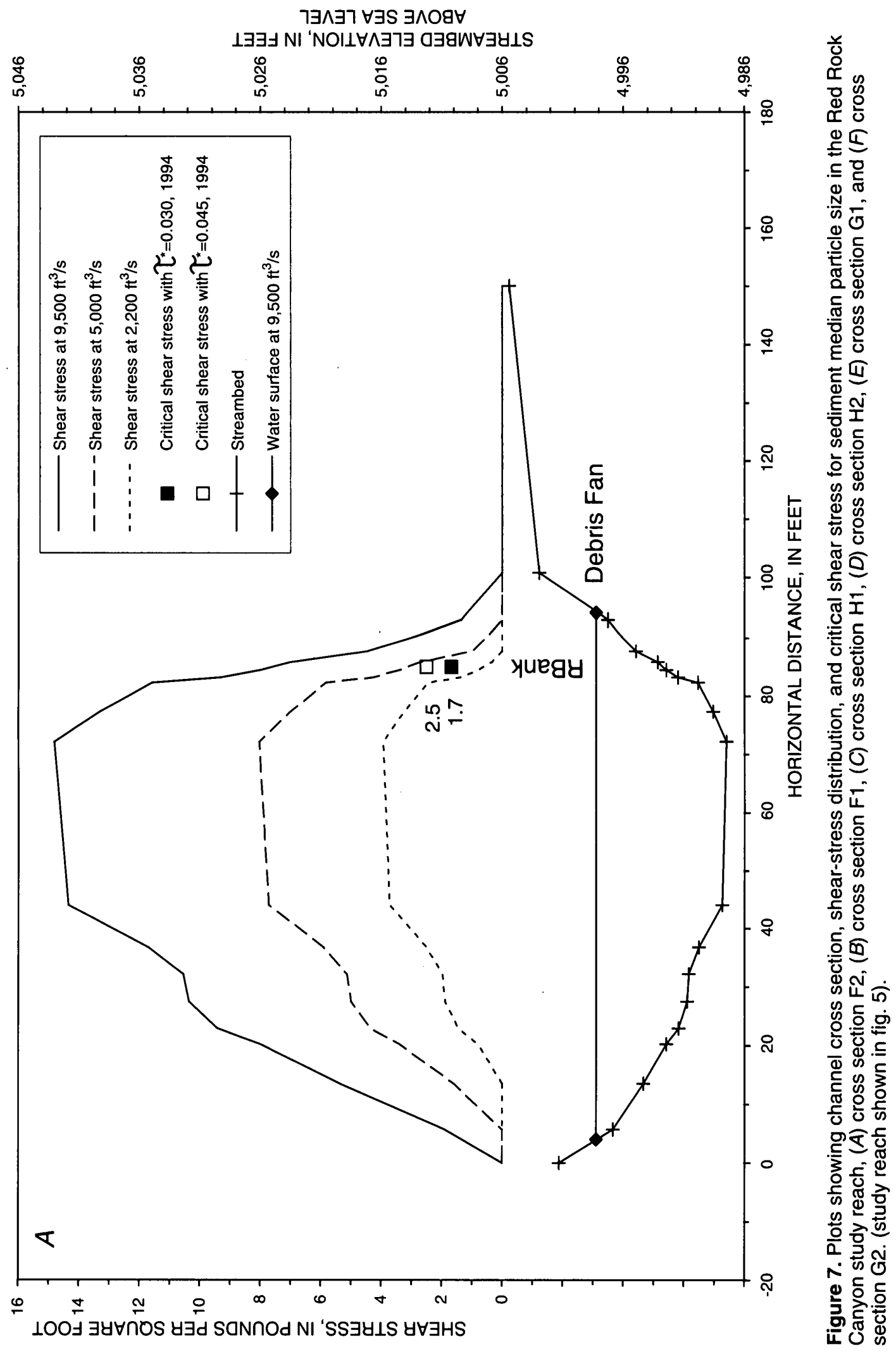




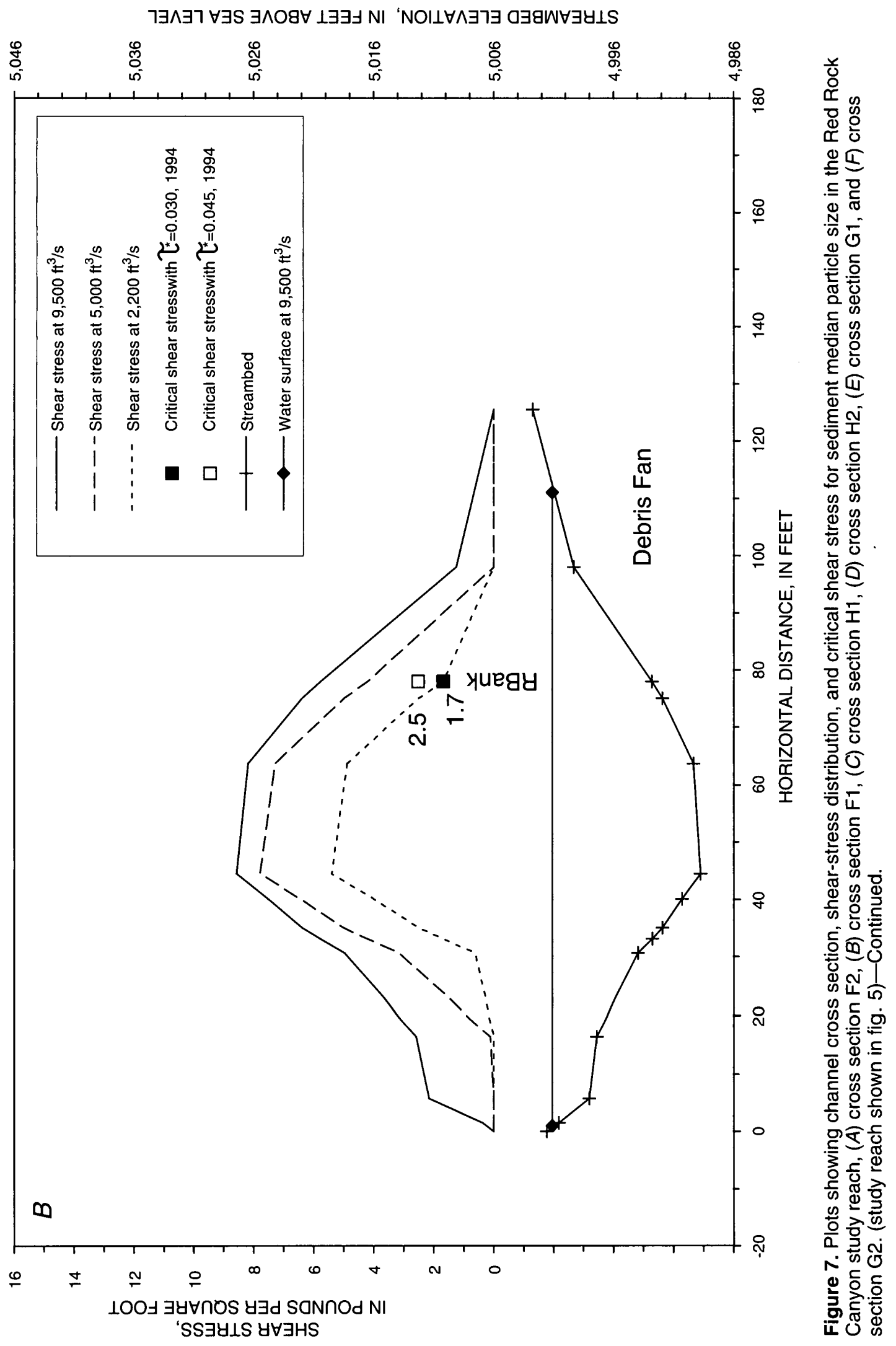




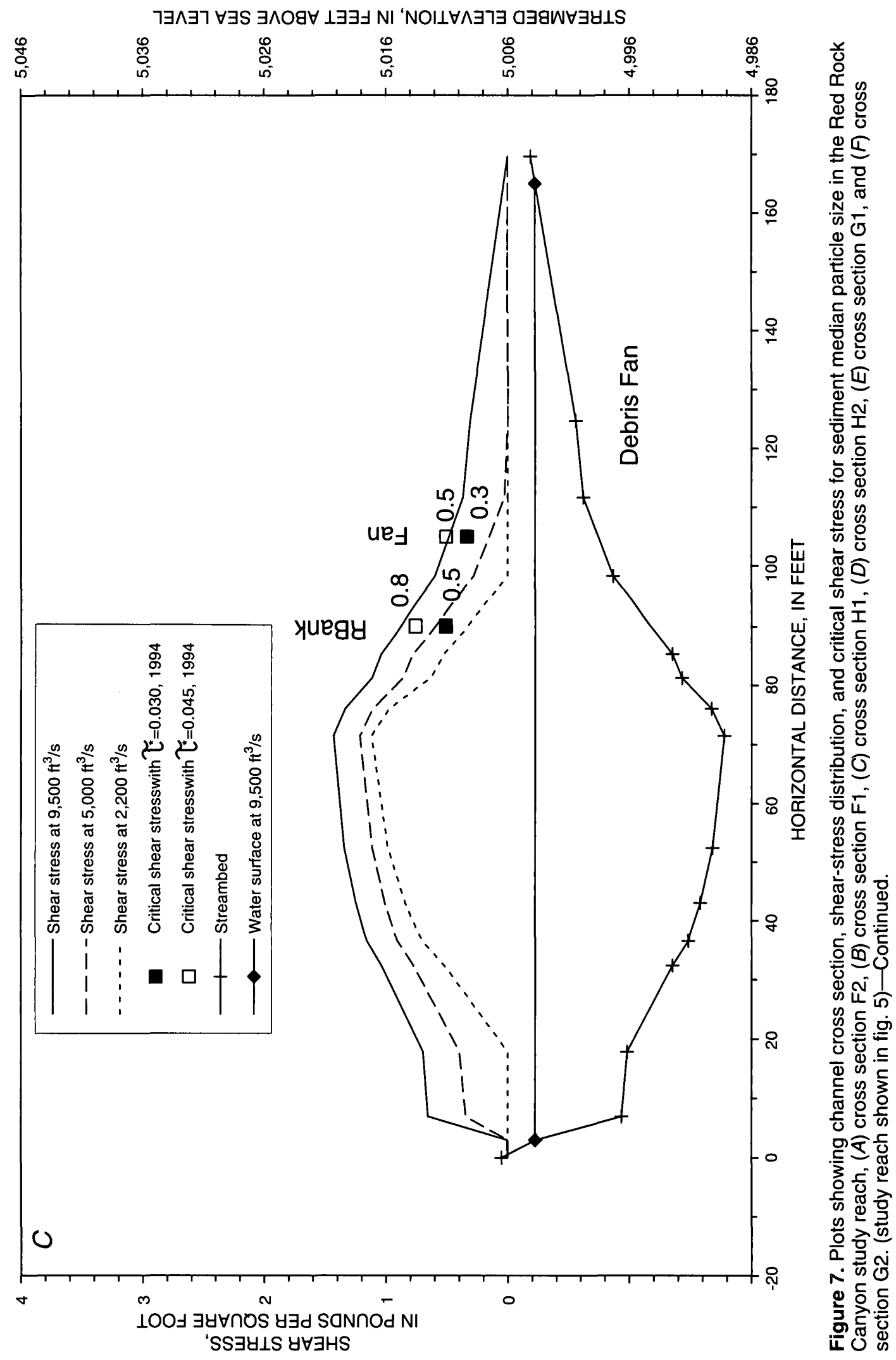




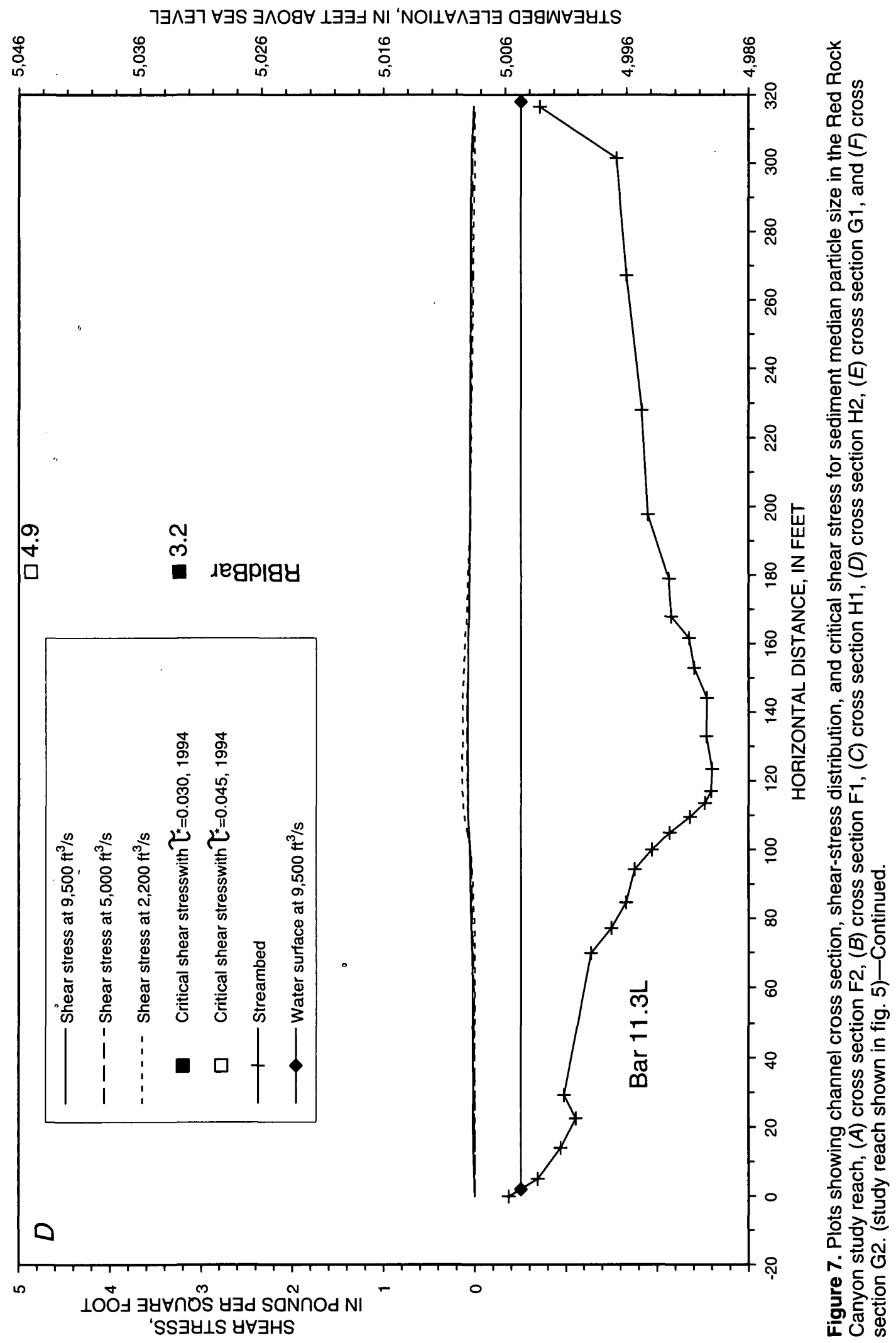




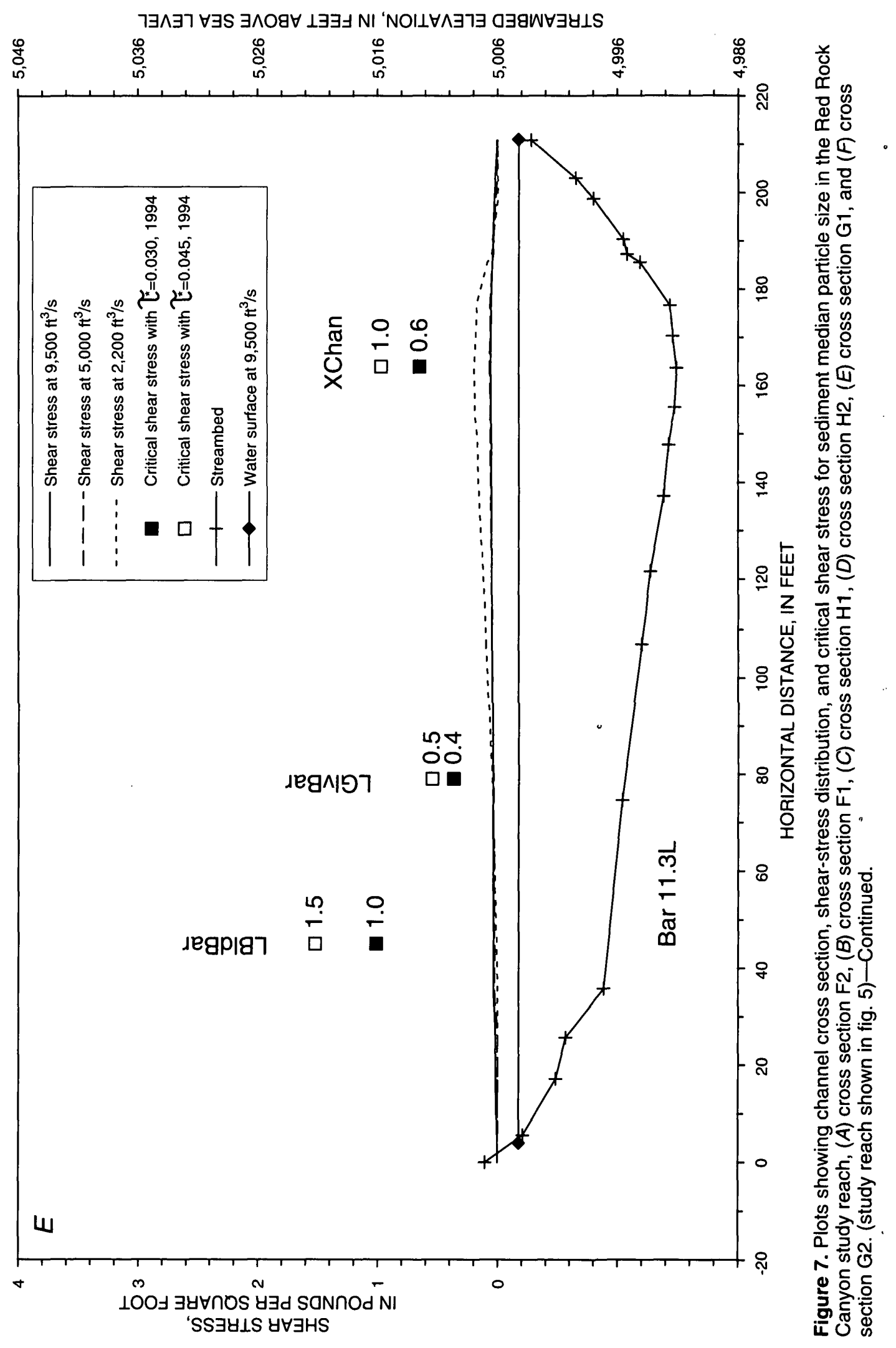




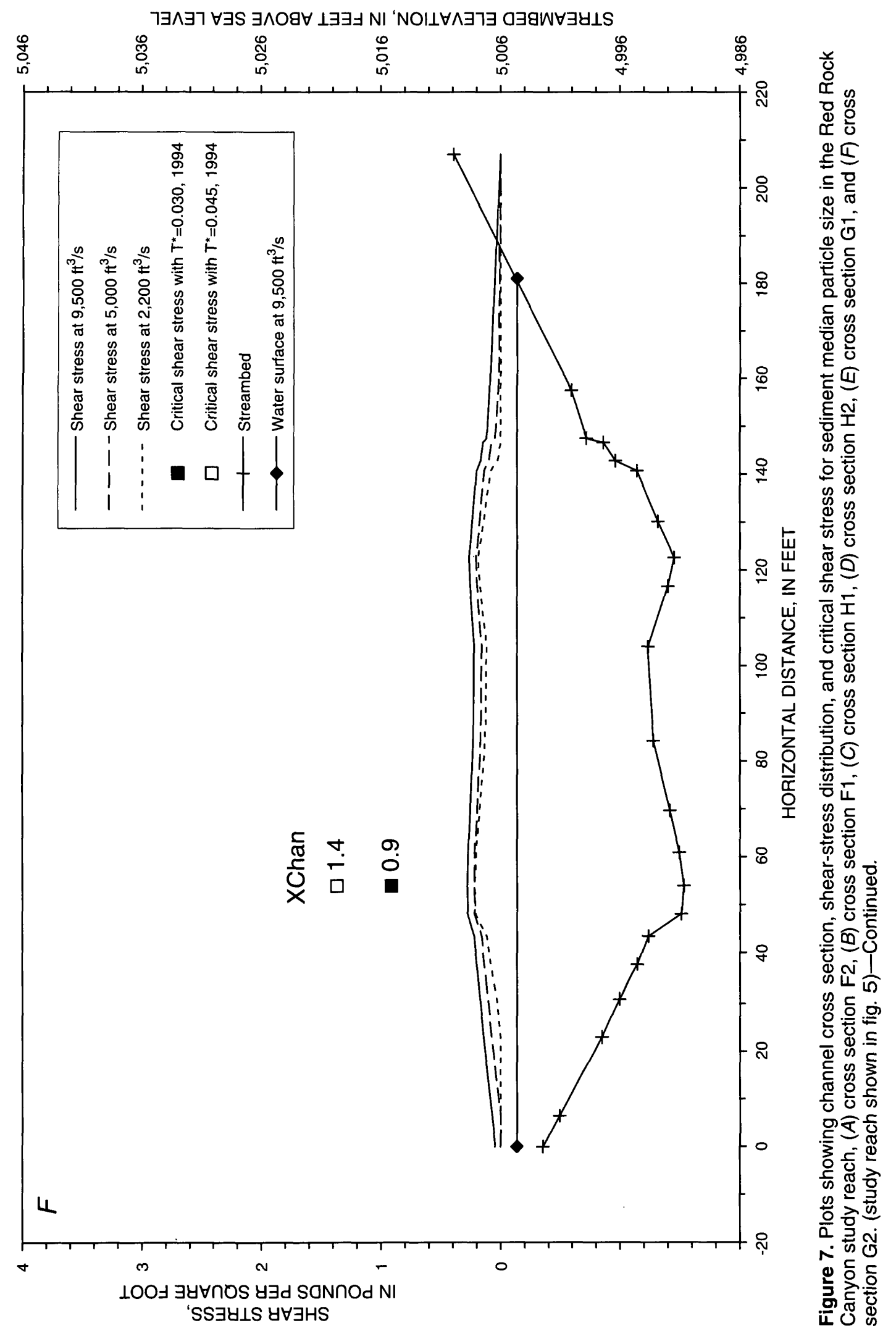


with sheltered particles, interlocked grains, or strong imbrication) had $\tau^{*}$ between 0.055 and 0.067 , whereas loosely structured beds (those with an openparticle framework) had $\tau^{*}{ }_{c}$ between 0.0096 and 0.011 .

The BLCA investigation did not include onsite observations of sediment entrainment and measurement of actual hydraulic conditions at the moment of sediment entrainment; therefore, the Shields parameter could not be precisely determined in this study as in some flume and instrumented field studies. Critical shear stresses for each sediment measurement were calculated with Shields $\tau^{*}{ }_{c}$ values of 0.030 and 0.045 to provide a range of the most likely entraining conditions (tables 3 and 4). Figures 6 and 7 show the lateral locations of sediment particle-size measurements and corresponding estimates of the critical shear stress for entrainment of sediment $d_{50}$ from the streambanks, alluvial bars, and overflow channels. Critical shear stress estimates for entrainment of sediment $d_{50}$ from the streambed (XChan in tables 3 and 4) are shown at the lateral location of the thalweg, or the deepest point of the channel cross section, in figures 6 and 7.

Reworked bank and bar sediments were observed at several measurement sites following the 1995 peak discharge $\left(9,470 \mathrm{ft}^{3} / \mathrm{s}\right)$. Using reconstructed flow depths and shear stresses associated with the peak discharge (Elliott and Hammack, in press), it appears that a Shields $\tau^{*}{ }_{c}$ value of 0.030 rather than 0.045 may provide the better estimates of critical shear stresses, $\tau_{c}$, and sediment entrainment at some locations in BLCA. Evidence of sediment entrainment or absence of sediment entrainment on inundated sedimentmeasurement sites in the Warner Point study reach after the 1995 peak discharge generally was consistent with critical shear stresses estimated using $\tau^{*}{ }_{c}$ of 0.030 and with the boundary shear stress generated by the discharge peak (figs. $6 B-6 H$ ).

Sediment was entrained by the 1995 peak discharge at all sediment-measurement sites on the distal margin of the debris fan in the Red Rock Canyon study reach. However, a recommended value of $\tau^{*}{ }_{c}$ could not be empirically determined because 1995 flood shear stresses were sufficiently larger than $\tau_{\mathrm{c}}$ calculated with $\tau^{*}{ }_{\mathrm{c}}$ values of either 0.030 or 0.045 (figs. $7 A-7 C$ ). Entrainment of sediment $\mathrm{d}_{50}$ probably occurred at a discharge much less than the 1995 peak discharge; therefore, threshold conditions could not be reconstructed using high-water marks as at other BLCA cross sections.
Onsite examination of a low-elevation gravel bar at cross section $\mathrm{G} 1$ in the Red Rock Canyon reach (see figs. $14 A$ and $14 B$ in appendix at back of report) indicated that sediment entrainment and reworking had occurred during the 1995 discharge peak. The relatively small $\mathrm{d}_{50}(36 \mathrm{~mm}$, table 4$)$ of this deposit and its proximity to the left low-flow bank implied that $\tau_{\mathrm{c}}$ probably was exceeded by a discharge much less than the 1995 flood peak. The boundary shear stresses, $\tau_{\mathrm{o}}$, calculated for the three reference discharges using HEC-RAS output clearly were much lower than the actual shear stresses at this location (fig. 7E). A likely explanation for the underestimated $\tau_{\mathrm{o}}$ is based on the limitations of a one-dimensional, water-surface profiles model when applied to a reach upstream from a significant lateral constriction such as the debris fan at the mouth of Tributary 11.3R in the Red Rock Canyon study reach (fig. 5). When discharge exceeds 2,200 to $3,000 \mathrm{ft}^{3} / \mathrm{s}$, a large, recirculating eddy develops on the right bank upstream from the debris fan, resulting in higher than anticipated velocities and shear stresses on the inundated left bank. The clear discrepancy between predicted $\tau_{0}$ and observed sediment reworking at cross section G1 illustrates a situation in which the one-dimensional model was inappropriately applied. Consequently, HEC-RASderived boundary shear-stress conditions upstream from the debris-fan constriction were not used in subsequent calculations or analyses (cross sections H2, G1, G2, G3, H3, and G4).

Sediment-entrainment potential for a variety of geomorphic surfaces can be expressed as the ratio of flood shear stress to the critical shear stress $\left(\tau_{\mathrm{o}} / \tau_{\mathrm{c}}\right)$ for a range of discharges. The $\tau_{\mathrm{o}} / \tau_{\mathrm{c}}$ ratio facilitates site-tosite comparison of the anticipated effects of specific discharges and integrates several geomorphic and sediment variables (flow depth, energy gradient, median particle size, critical shear stress) over a wide range of values (Elliott and Hammack, in press). Graphs of the sediment-entrainment potential for several selected geomorphic surfaces in the Warner Point (fig. 8) and Red Rock Canyon (fig. 9) study reaches provide a way to estimate the relative effects of different hypothetical peak discharges. The geomorphic surfaces examined included (a) low-flow banks (fig. $8 A$ ), surfaces subaerially exposed much of the year but inundated by discharges of approximately 700 to $900 \mathrm{ft}^{3} / \mathrm{s}$ (RI less than 1 year); (b) lowbar surfaces (fig. $8 \mathrm{~B}$ ), fluvial deposits inundated by approximately 2,000 to $4,000 \mathrm{ft}^{3} / \mathrm{s}$ (RI 1.2 to 


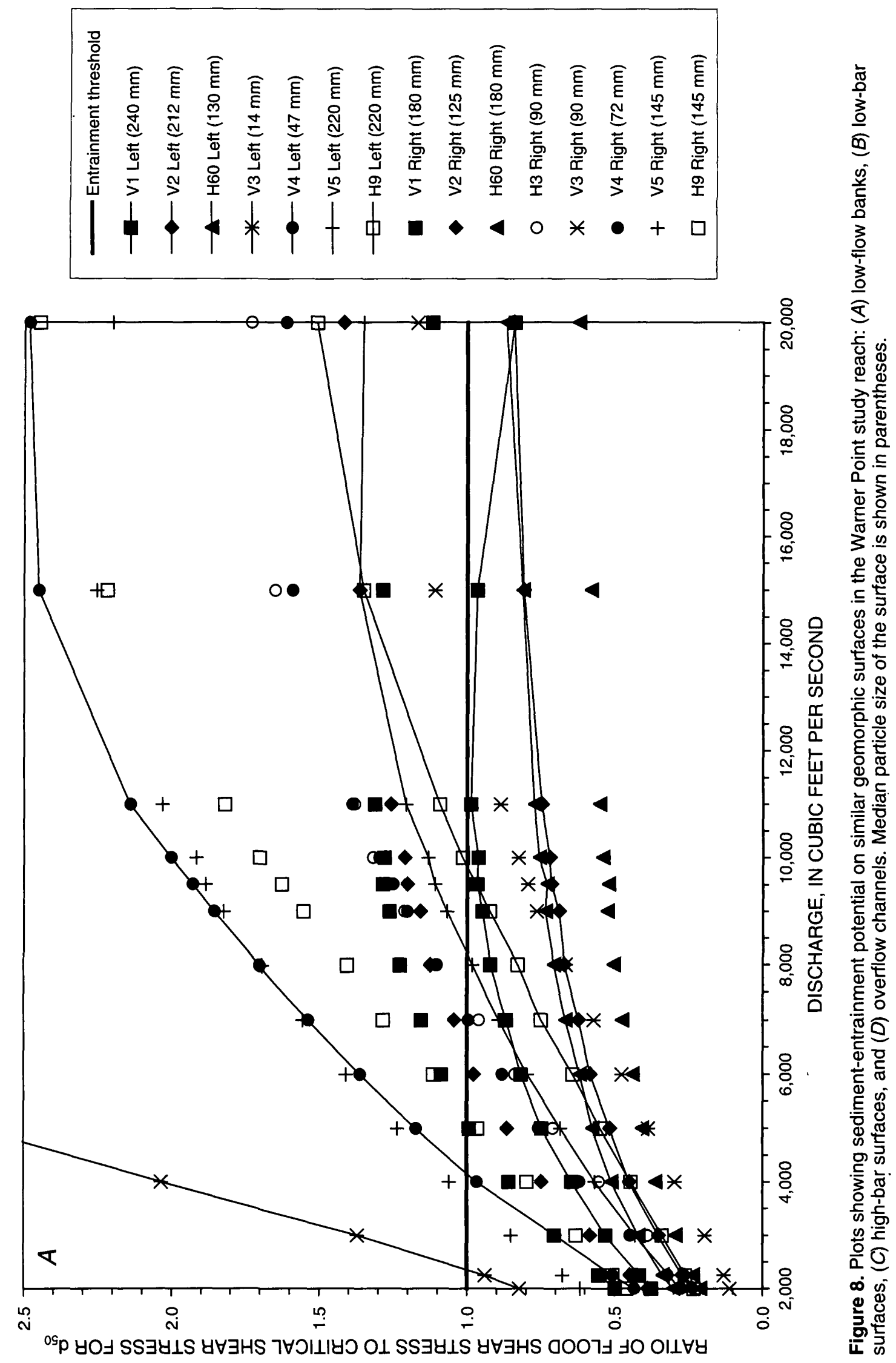




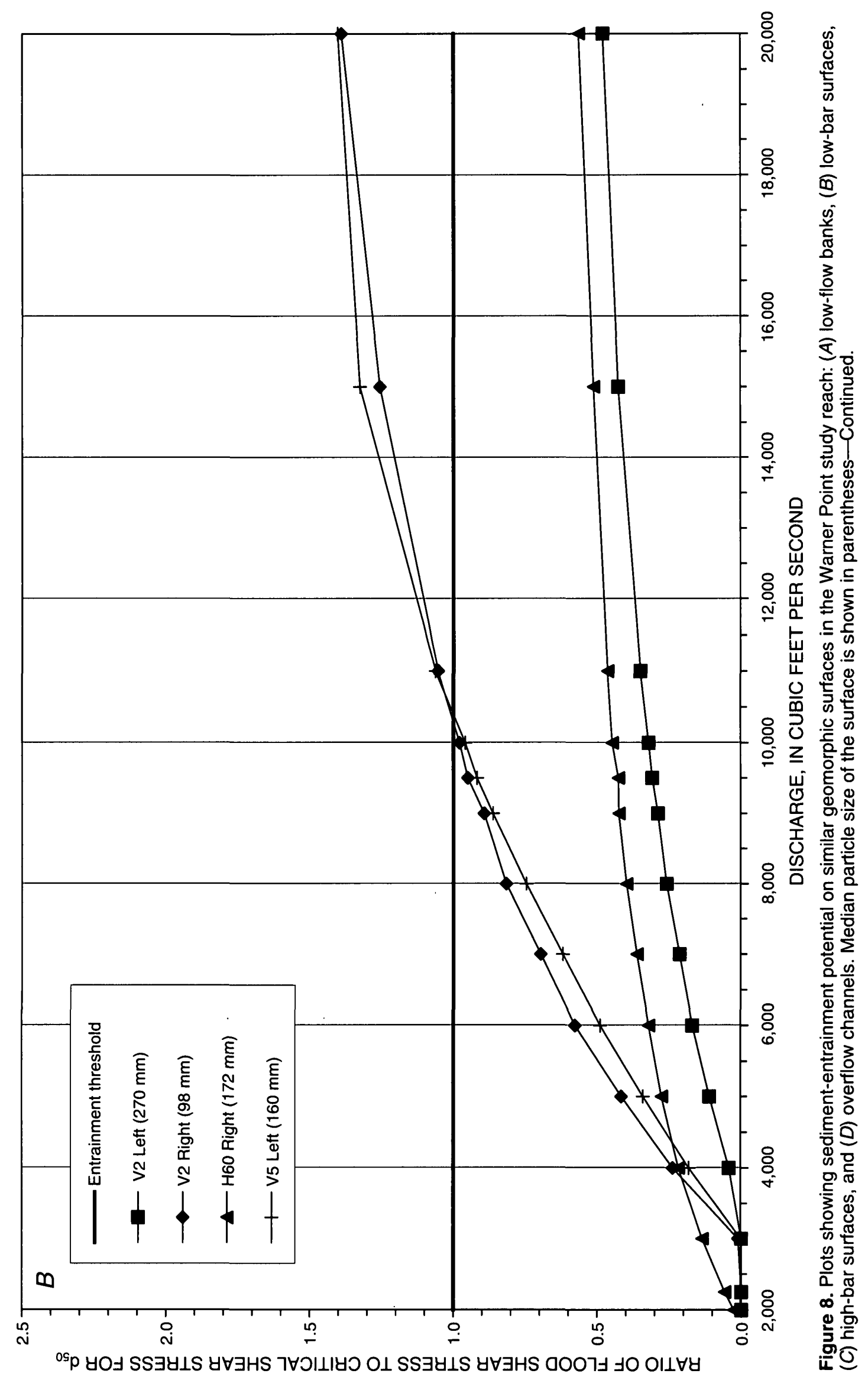




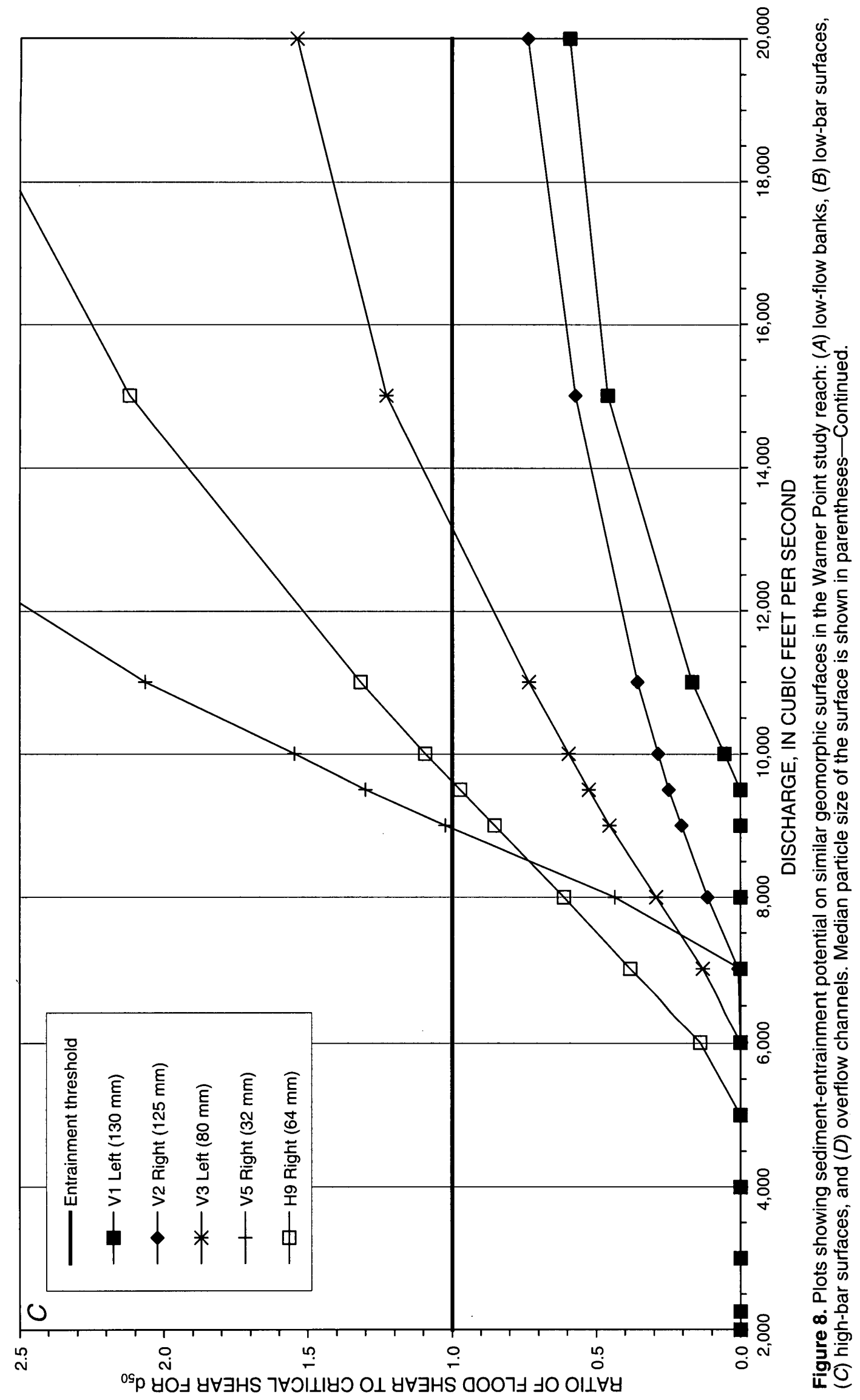




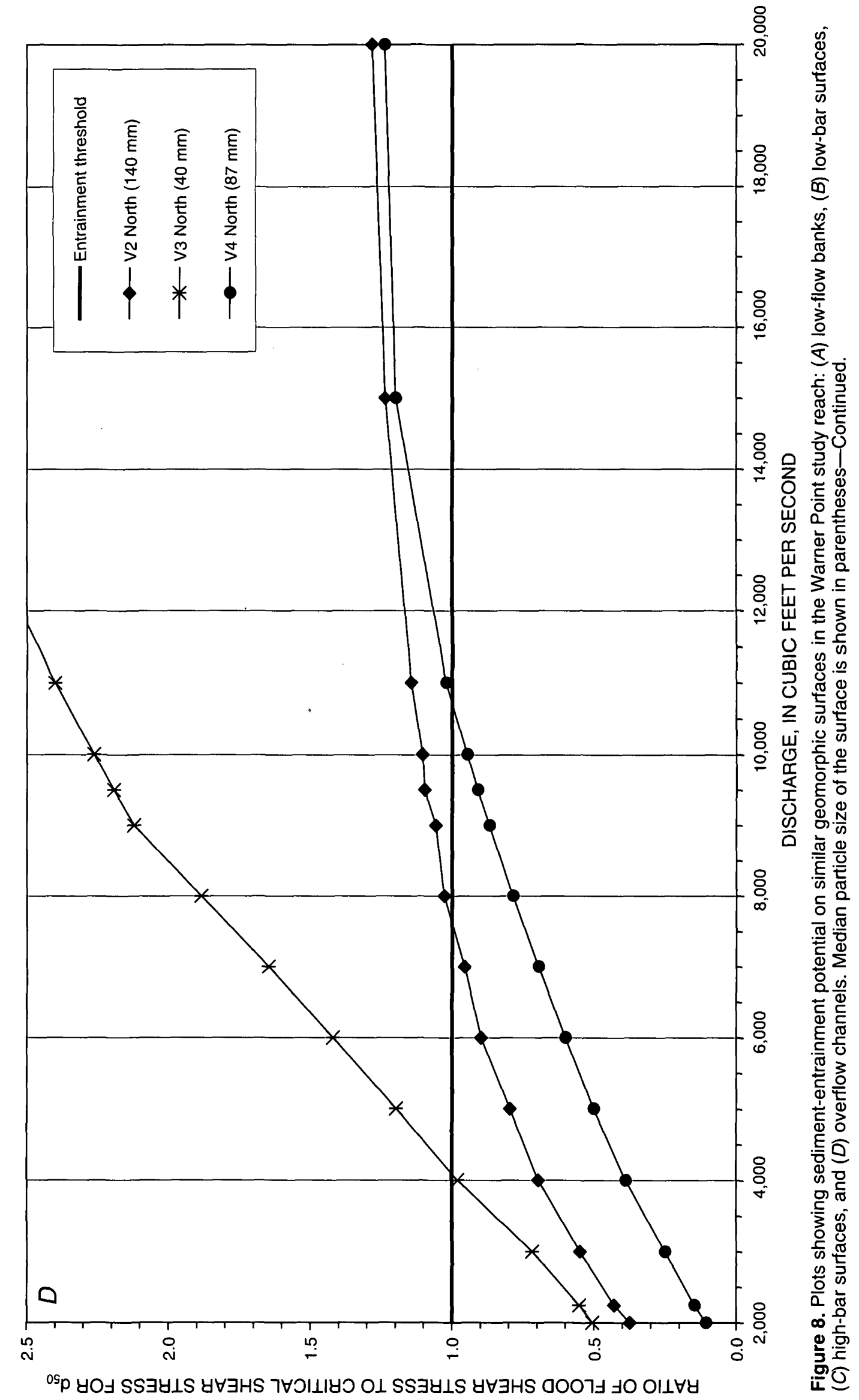




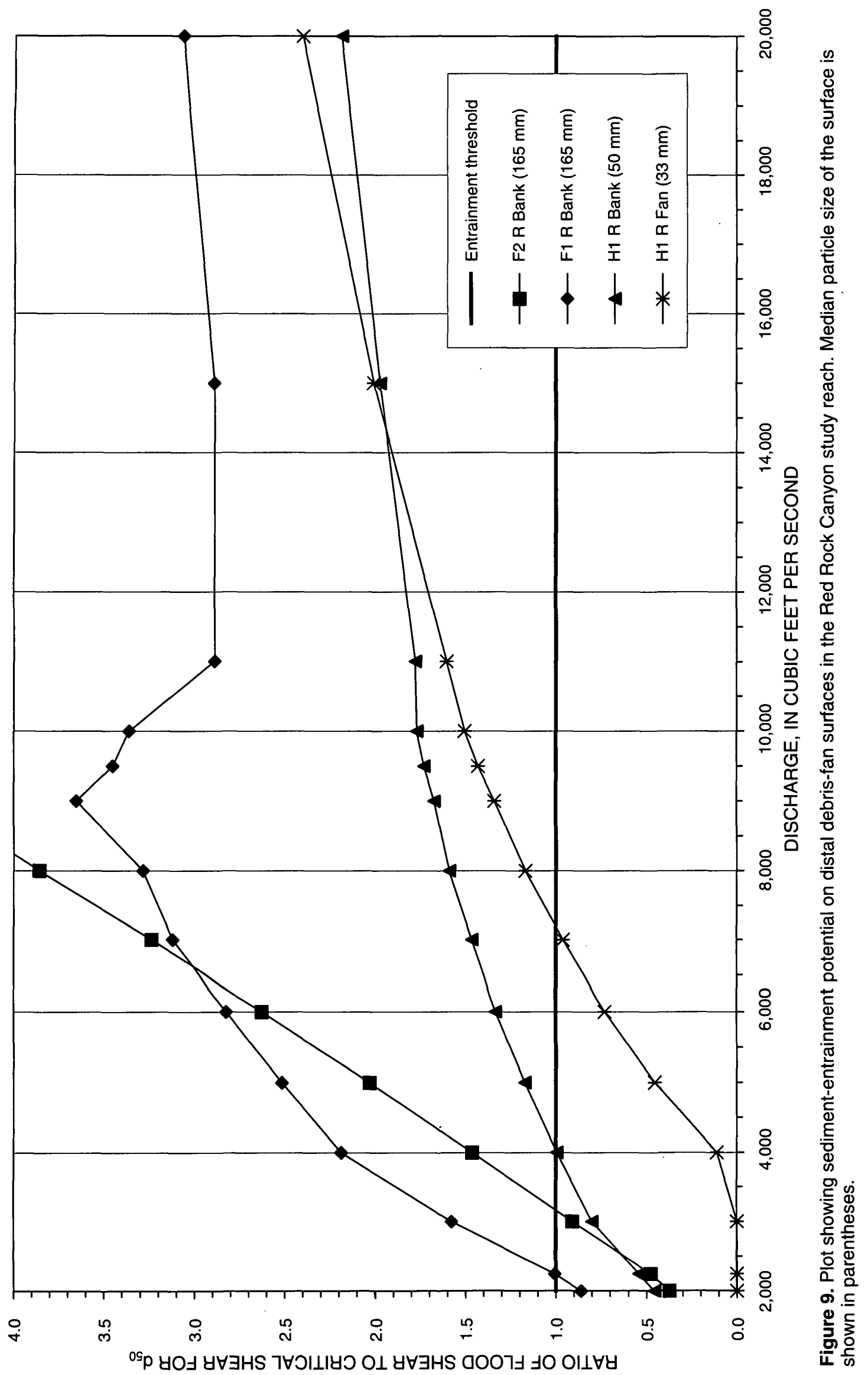


2.5 years); (c) high-bar surfaces (fig. $8 C$ ), fluvial deposits inundated by approximately 6,000 to $10,000 \mathrm{ft}^{3} / \mathrm{s}$ (RI 6 to 35 years); (d) overflow channels (fig. $8 D$ ), water courses situated between large fluvial bars and adjacent talus slopes inundated by approximately 500 to $1,500 \mathrm{ft}^{3} / \mathrm{s}$ (RI less than 1 year); and (e) a recent tributary debris-flow deposit (fig. 9) inundated by approximately $4,000 \mathrm{ft}^{3} / \mathrm{s}$ (RI 2.5 years).

A $\tau^{*}{ }_{c}$ value of 0.030 and the sediment $d_{50}$ were used in the calculations represented in figures 8 and 9 . In most locations, $\tau_{\mathrm{o}}$ increases with discharge, whereas $\tau_{c}$ is constant for a given sediment $d_{50}$. The ratio of $\tau_{\mathrm{o}} / \tau_{\mathrm{c}}$ generally increases with discharge, although the rate of change and the value of $\tau_{\mathrm{o}} / \tau_{\mathrm{c}}$ vary with channel configuration, local energy gradient, and sediment size. Entrainment is anticipated, and the critical discharge is attained when $\tau_{\mathrm{o}} / \tau_{\mathrm{c}}$ exceeds a threshold value of 1.0; but as figures 8 and 9 illustrate, the critical discharge is not unique for similar geomorphic surfaces at different cross sections. Differing entrainment potential for similar geomorphic surfaces (low-flow banks, low-elevation bars, high-elevation bars, and so forth) indicates that estimation of minimum streamflow requirements based on sediment mobility requires site-specific geomorphic and sedimentologic data.

The left banks at cross sections V1, V2, and $\mathrm{H} 60$ (fig. 8A), the right bank at $\mathrm{H} 60$ (fig. $8 A$ ), the left low bar at cross section V2 (fig. $8 B$ ), and the right low bar at cross section $\mathrm{H} 60$ (fig. $8 B$, shown in figs. $13 A$ and $13 B$ in appendix) are relatively coarse and potentially are exposed to very high shear stresses.

However, the $\tau_{\mathrm{o}} / \tau_{\mathrm{c}}$ curves for these sites appear to be asymptotic with respect to the entrainment threshold line, indicating that entrainment of $\mathrm{d}_{50}$ from these surfaces is unlikely at any discharge. One possible explanation is that the sediment of Bars $8.7 \mathrm{~L}, 8.5 \mathrm{~L}$, and $8.5 \mathrm{R}$ (fig. 4 ) may be vestiges of an earlier, more competent flow regime or of different channel configurations such that no discharge, at least as large as the modeled $20,000 \mathrm{ft}^{3} / \mathrm{s}$, will entrain $\mathrm{d}_{50}$, given the present channel geometry.

\section{SUMMARY}

The Black Canyon of the Gunnison River in western Colorado, known for its precipitous bedrock exposures and gorge-like characteristics, also includes several alluvial reaches that are potentially sensitive to changes in streamflow. Sediment, derived from talus slopes, rockfall, and tributary debris flows, periodically is reworked and redeposited on the streambed, streambanks, and alternate bars in these alluvial reaches. Geomorphic and sedimentologic data were collected from two alluvial reaches in the Black Canyon of the Gunnison National Monument (BLCA) - the Warner Point study reach and the Red Rock Canyon study reach. These data and hydrologic records from an upstream gaging station were used to calculate the entrainment potential of a large sizerange of sediment on a variety of fluvial geomorphic surfaces typical of the Black Canyon and other canyon rivers.

The Gunnison River hydrology is dominated by snowmelt runoff; however, impoundments and diversion upstream from BLCA have affected the streamflow magnitude and duration since 1966 . The 10-year flood decreased from 14,900 to $7,000 \mathrm{ft}^{3} / \mathrm{s}$ and the 5 -year flood from 12,700 to $5,460 \mathrm{ft}^{3} / \mathrm{s}$. While reservoir operation has attenuated flood peaks in BLCA, it also has augmented moderate streamflows. The duration of streamflows between 1,140 and $3,000 \mathrm{ft}^{3} / \mathrm{s}$ has increased from an average of 12 percent of the time, an average of about 44 days per year (1911-65), to 38 percent of the time, an average of about 139 days per year (1966-94).

The one-dimensional water-surface profiles models HEC-2 and HEC-RAS were used to estimate water-surface elevations, flow depths, and hydraulic conditions through the study reaches for a range of discharges from 2,000 to $20,000 \mathrm{ft}^{3} / \mathrm{s}$. These models used surveyed channel cross sections and were calibrated with observed water-surface elevations and high-water marks in the Warner Point and Red Rock Canyon reaches. The HEC- 2 models were calibrated by varying the Manning's $n$ roughness coefficient until the estimated water-surface elevations nearly equaled the surveyed water-surface elevations. Discharges at the Warner Point and Red Rock Canyon reaches were assumed to be comparable to discharges recorded a few hours earlier at USGS gaging station 09128000 upstream.

The hydraulic models appeared to adequately simulate observed water surfaces and hydraulic conditions except in the reach affected by backwater and a large, high-flow, recirculating eddy upstream from the debris-flow constriction in the Red Rock Canyon study reach. Estimated water-surface elevations were very close to surveyed elevations for most calibration 
discharges having differences less than 10 percent of the calculated maximum flow depth for a specific discharge. HEC-2 and HEC-RAS output from the modeling runs included water-surface elevations and energy gradients, from which flow depths and boundary shear stresses at specific locations on the cross sections were calculated.

The low-flow channel of most cross sections in the study reaches is composed of material in the large cobble- and boulder-size range; however, streambanks and bars are composed of finer material in the gravel-, cobble-, and occasionally boulder-size range. Shear stresses acting on the streambed, on streambanks, and on inundated alluvial bars is highly variable for any specific discharge and is dependent, in part, on the local flow depth and energy gradient of the river. Consequently, conditions for sediment entrainment, sorting, and deposition also are spatially variable. Data from the hydraulic models and sediment data measured at several locations were used to calculate the entrainment potential of a wide range of sediment sizes on several geomorphic surfaces. Sediment entrainment is anticipated when the local boundary shear stress, $\tau_{\mathrm{o}}$, exceeds the critical shear stress, $\tau_{\mathrm{c}}$, of the sediment comprising a specific surface.

Critical shear stresses were calculated for several alluvial deposits by using dimensionless critical shear stress values, or Shields $\tau^{*}{ }_{c}$, of 0.030 and 0.045 because a precise $\tau^{*}$ c value for each sediment deposit could not be determined. A peak discharge of $9,470 \mathrm{ft}^{3} / \mathrm{s}$ in 1995 and onsite observations and photographs in 1994 and 1995 confirmed sediment entrainment or reworking on several geomorphic surfaces inundated by the peak discharge. Physical evidence of sediment entrainment, or absence of sediment entrainment, on inundated sediment-measurement sites generally was consistent with critical shear stresses estimated with $\tau^{*}{ }_{c}$ of 0.030 in the Warner Point study reach; however, a preferred $\tau^{*}{ }_{c}$ could not be determined for the debris-fan distal margin in the Red Rock Canyon study reach. A $\tau^{*}{ }_{c}$ value other than 0.030 could be appropriate for some geomorphic surfaces in the study reach; however, determination of $\tau^{*}{ }_{c}$, such as by the method of Andrews (1983), could not be made in this study.

Entrainment potential over a range of discharges can be summarized by the ratio of boundary shear stress to the critical shear stress $\left(\tau_{\mathrm{o}} / \tau_{\mathrm{c}}\right)$, given local hydraulic geometry and sediment-size characteristics. Differing entrainment potential for similar geomor- phic surfaces (low-flow banks, low-elevation bars, high-elevation bars, and so forth) indicates that estimation of minimum streamflow requirements based on sediment mobility require site-specific geomorphic and sedimentologic data.

\section{REFERENCES CITED}

Andrews, E.D., 1983, Entrainment of gravel from naturally sorted riverbed material: Geological Society of America Bulletin, v. 94, p. 1225-1231.

Arcement, G.J., and Schneider, V.R., 1989, Guide for selecting Manning's roughness coefficients for natural channels and flood plains: U.S. Geological Survey Water-Supply Paper 2339, 38 p.

Barnes, H.H., Jr., 1967, Roughness characteristics of natural channels: U.S. Geological Survey Water-Supply Paper $1849,213 \mathrm{p}$.

Carling, P.A., 1983, Threshold of coarse sediment transport in broad and narrow natural streams: Earth Surface Processes, v. 8, p. 1-18.

Chow, V.T., 1959, Open-channel hydraulics: New York, McGraw-Hill, Inc., 680 p.

Elliott, J.G., and Hammack, L.A., in press, Entrainment of riparian gravel and cobbles in an alluvial reach of a regulated canyon river: Regulated Rivers-Research and Management.

Elliott, J.G., and Parker, R.S., 1992, Potential climatechange effects on bed-material entrainment, the Gunnison Gorge, Colorado, in Hermann, Raymond, ed., Managing water resources during global change: Proceedings, American Water Resources Association, 28th Annual Conference and Symposia, Reno, Nevada, November 1-5, 1992, p. 751-759.

Elliott, J.G., and Parker, R.S., 1997, Altered streamflow and sediment entrainment in the Gunnison Gorge: Journal of the American Water Resources Association, v. 33, no. 5, October 1997, p. 1041-1054.

Fahnestock, R.K., 1963, Morphology and hydrology of a glacial stream-White River, Mount Rainier, Washington: U.S. Geological Survey Professional Paper 442-A, p. 1-70.

Friedman, J.M., and Auble, G.T., in press, Mortality of riparian box elder from sediment mobilization and extended inundation: Regulated Rivers-Research and Management.

Hansen, W.R., 1965, The Black Canyon of the Gunnison today and yesterday: U.S. Geological Survey Bulletin $1191,76 \mathrm{p}$.

Hydrologic Engineering Center, 1990, HEC-2 Water surface profiles-Program user's manual: U.S. Army Corps of Engineers, 47 p. 
Hydrologic Engineering Center, 1997, HEC-RAS River analysis system-Program user's manual, Version 2.0: U.S. Army Corps of Engineers, variously paged.

Komar, P.D., 1987, Selective gravel entrainment and the empirical evaluation of flow competence: Sedimentology, v. 34, p. 1165-1176.

Lane, E.W., 1955, Design of stable channels: Transactions, American Society of Civil Engineers, v. 120, no. 2776, p. 1234-1279.

Lisle, T.E., Iseya, F., and Ikeda, H., 1993, Response of a channel with alternate bars to a decrease in supply of mixed-size bed load-A flume experiment: Water Resources Research v. 29, no. 11, p. 3623-3629.

Milhous, R.T., 1982, Effect of sediment transport and flow regulation on the ecology of gravel-bed rivers, in Hey, R.D., Bathhurst, J.C., and Thorne, C.R., eds., Gravel-bed rivers: Chichester, England, John Wiley and Sons, Limited, p. 819-842.

Neill, C.R., 1968, A re-examination of the beginning of movement for coarse granular bed materials: Wallingford, United Kingdom, Hydraulics Research Station, Report No. INT 68, 37 p.

Parker, Gary, Klingman, P.C., and McLean, D.G., 1982, Bedload and size distribution in paved gravel-bed streams: American Society of Civil Engineers, Journal of the Hydraulics Division 108(HY4) p. $544-571$.

Powell, D.M., and Ashworth, P.J., 1995, Spatial pattern of flow competence and bed load transport in a divided gravel bed river: Water Resources Research, v. 31 , no. 3 , p. $741-752$.
Shields, A., 1936, Application of similarity principles and turbulence research to bedload movement, translated from Anwendung der Aehnlichkeitsmechanik und der Turbulenzforschung auf die Geschiebewegung: Mitteilung Preussischen Versuchanstalt für Wasserbau und Schiffbau, Berlin, No. 26, by W.P. Ott and J.C. van Uchelen, California Institute of Technology Hydrodynamics, Pasadena, California, Report No. 167, 43 p.

U.S. Interagency Advisory Committee on Water Data, 1982, Guidelines for determining flood-flow frequency, Bulletin 17B of the Hydrology Subcommittee: Reston, Va., U.S. Geological Survey, Office of Water Data Coordination, 183 p.

Warner, M.T., and Walker, D.B., 1972, Through the Black Canyon: Ann Arbor, Michigan, BraunBrumfield, Inc., 45 p.

Webb, R.H., 1996, Grand Canyon, a century of environmental change-Rephotography of the 1889-1890 Stanton Expedition: Tucson, University of Arizona Press, $290 \mathrm{p}$.

Webb, R.H., Melis, T.S., Wise, T.W., and Elliott, J.G., 1996, The great cataract-Effects of late Holocene debris flows on Lava Falls Rapid, Grand Canyon National Park and Hualapai Indian Reservation, Arizona: U.S. Geological Survey Open-File Report 96-460, $96 \mathrm{p}$.

Wilcock, P.R., 1992, Flow competence-A criticism of a classic concept: Earth Surface Processes and Landforms, v. 17, p. 289-298.

Wilcock, P.R., and McArdell, B.W., 1993, Surface-based fractional transport rates-Mobilization thresholds and partial transport of a sand-gravel sediment: Water Resources Research v. 29, no. 4, p. 1297-1312.

Wolman, M.G., 1954, A method of sampling coarse riverbed material: American Geophysical Union Transactions v. 35, p. 951-956. 

APPENDIX 


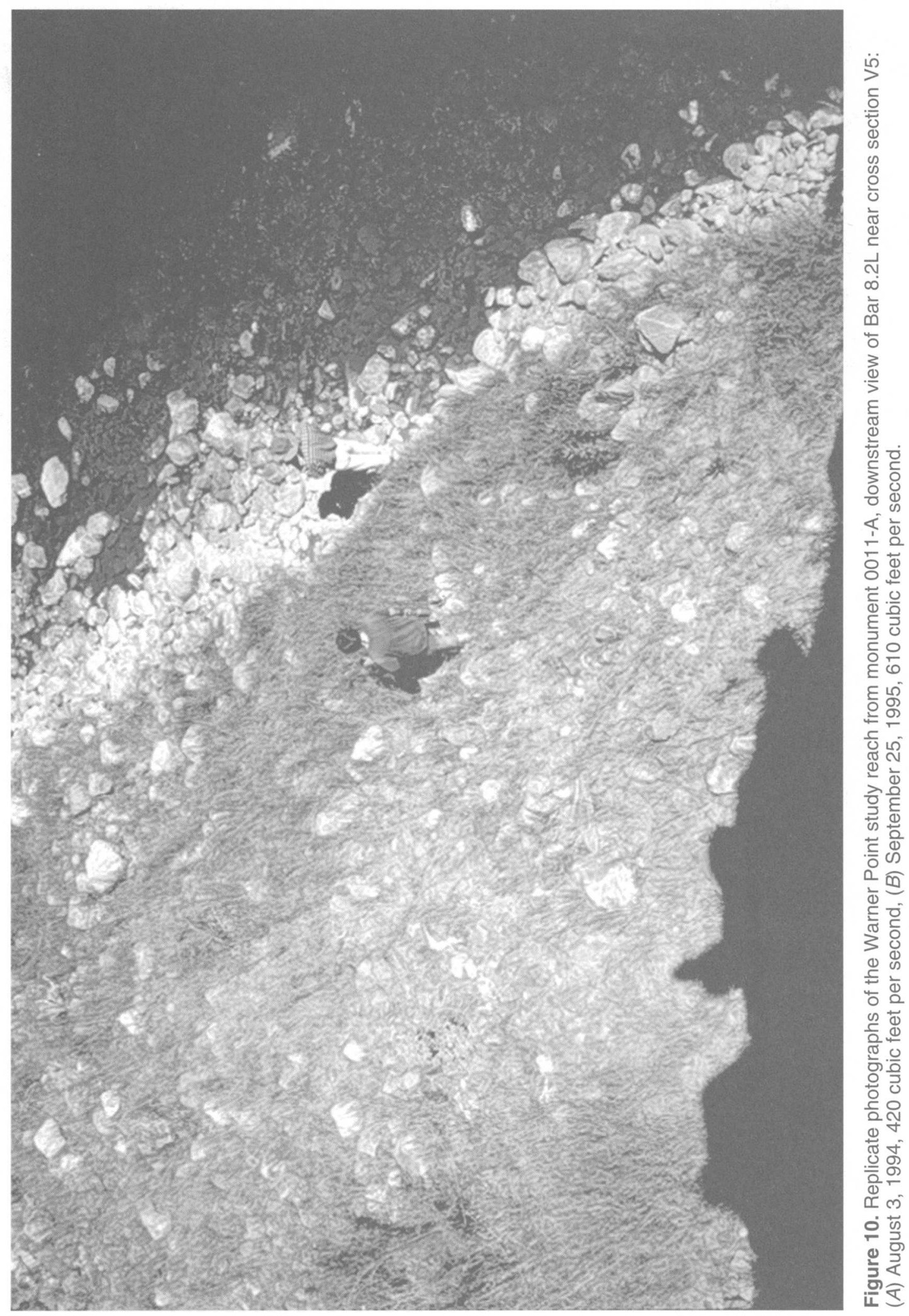

$\varangle$ 

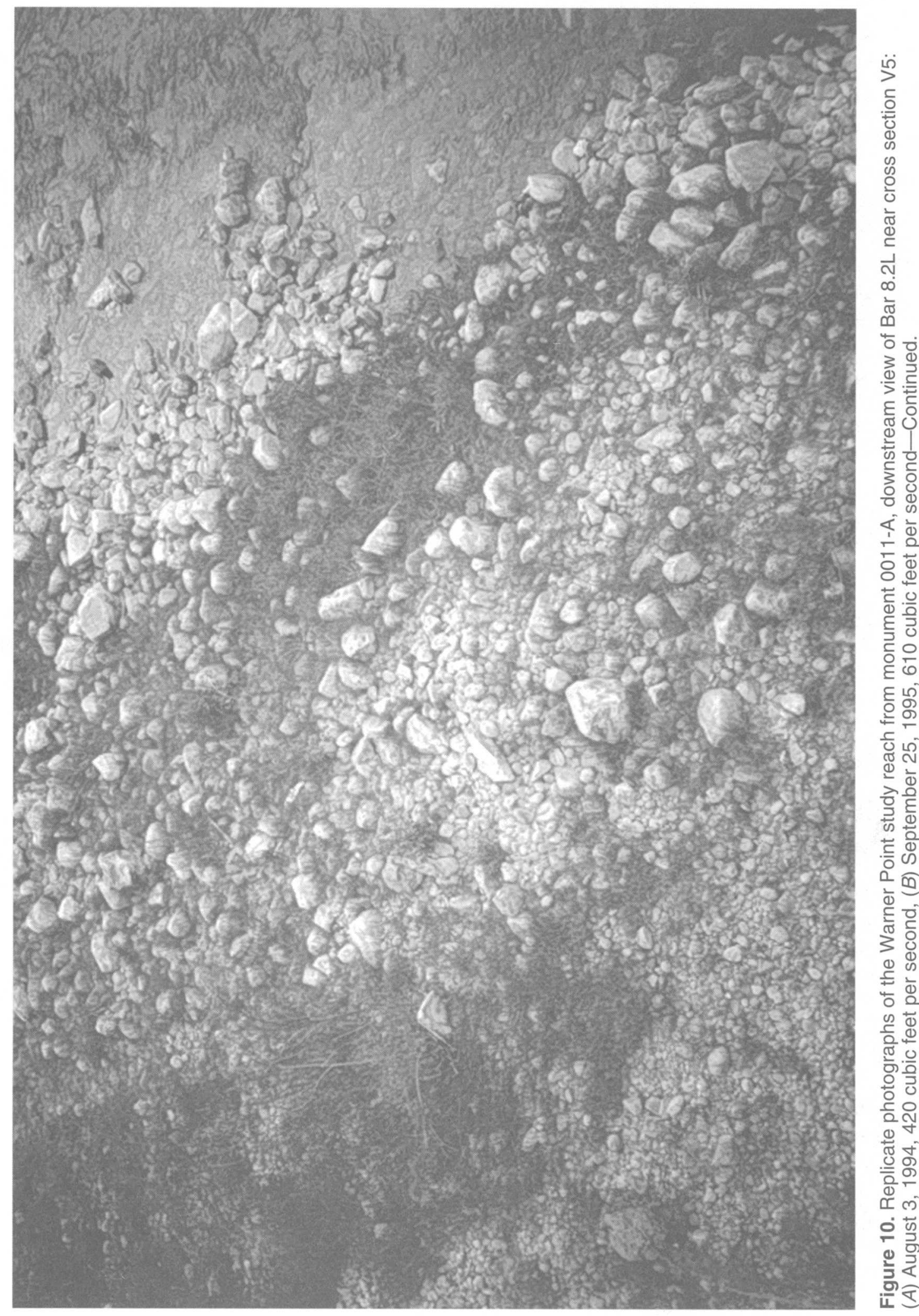

$m$ 


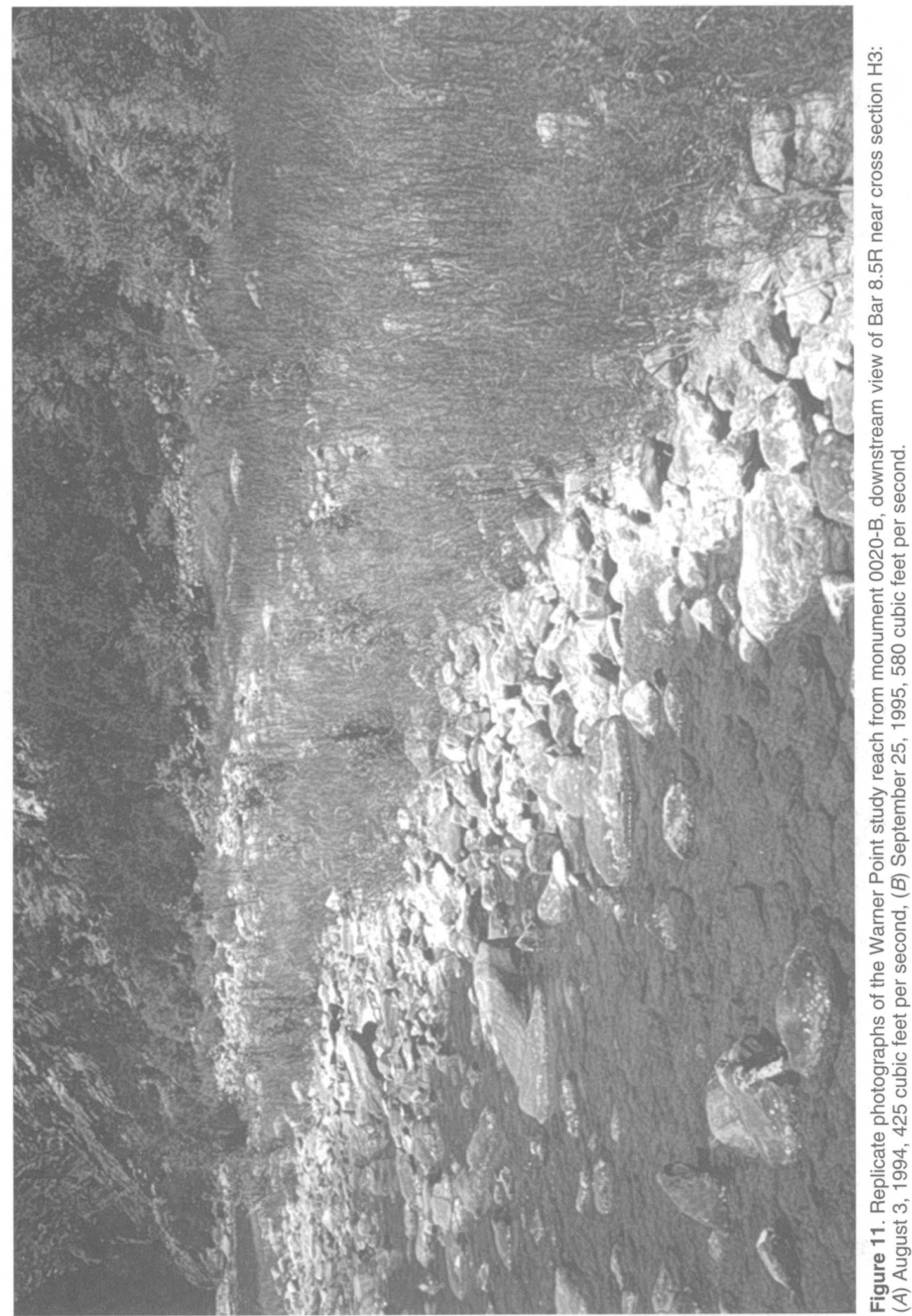

$\varangle$ 


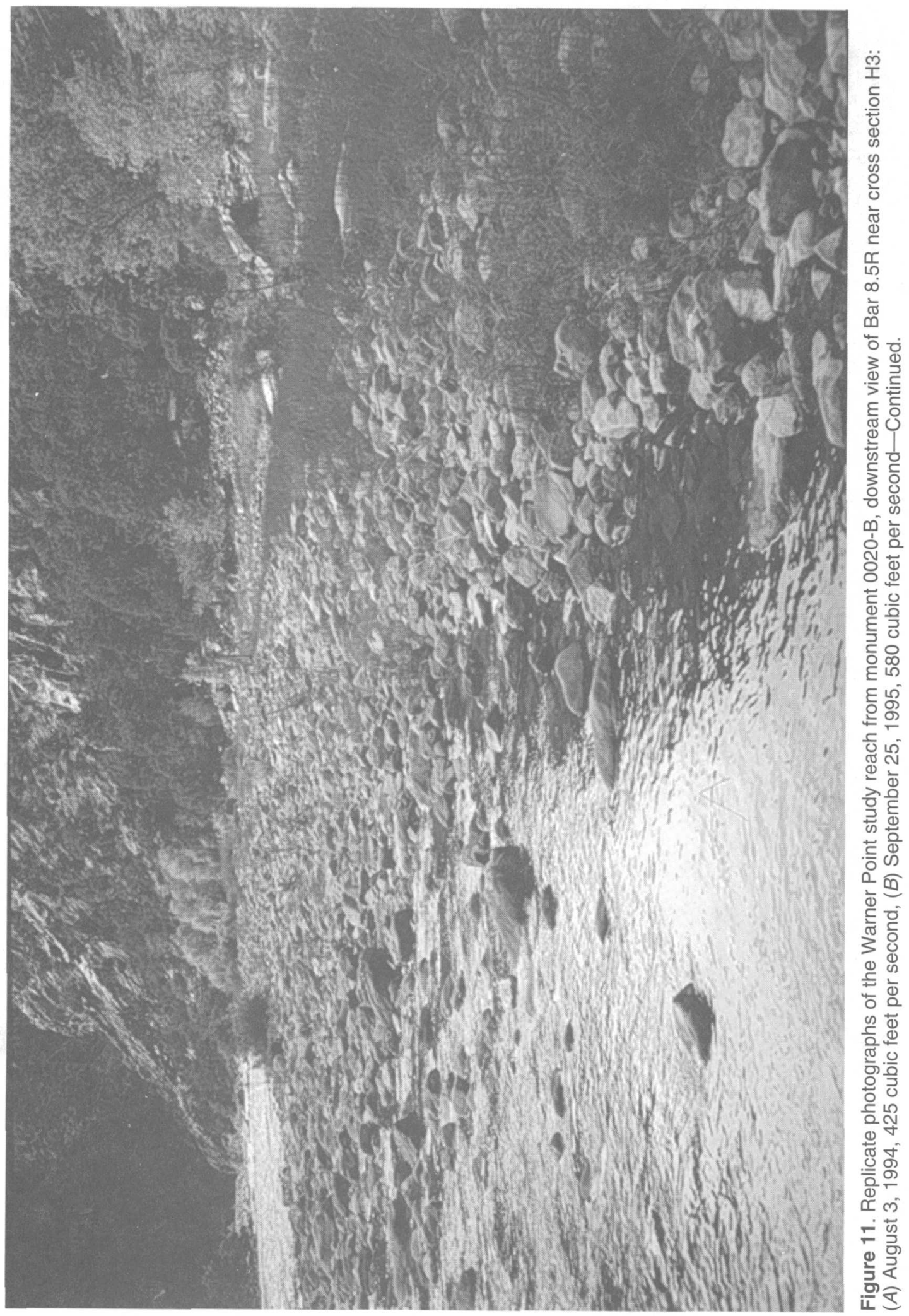

$\infty$ 


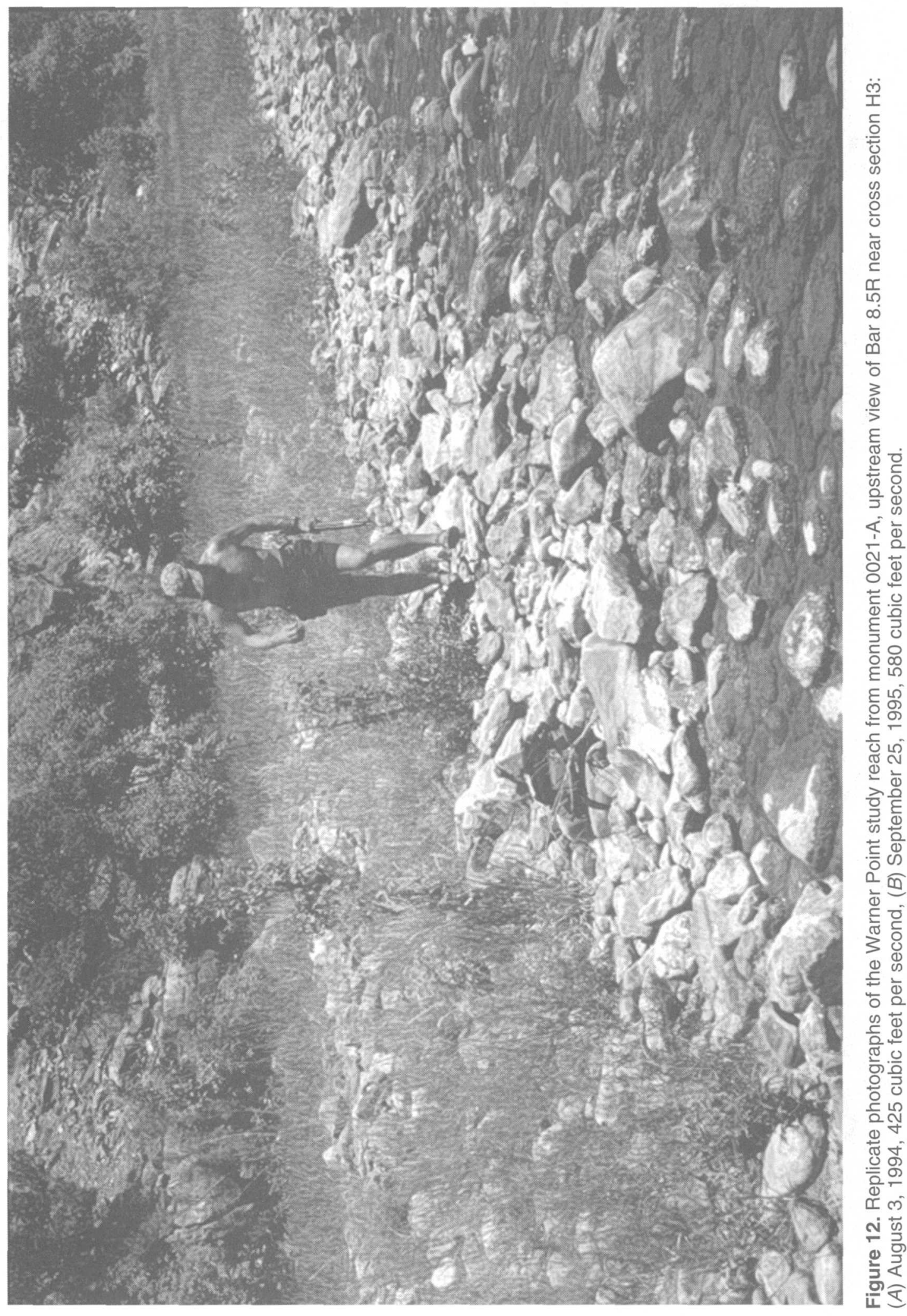

$\varangle$ 


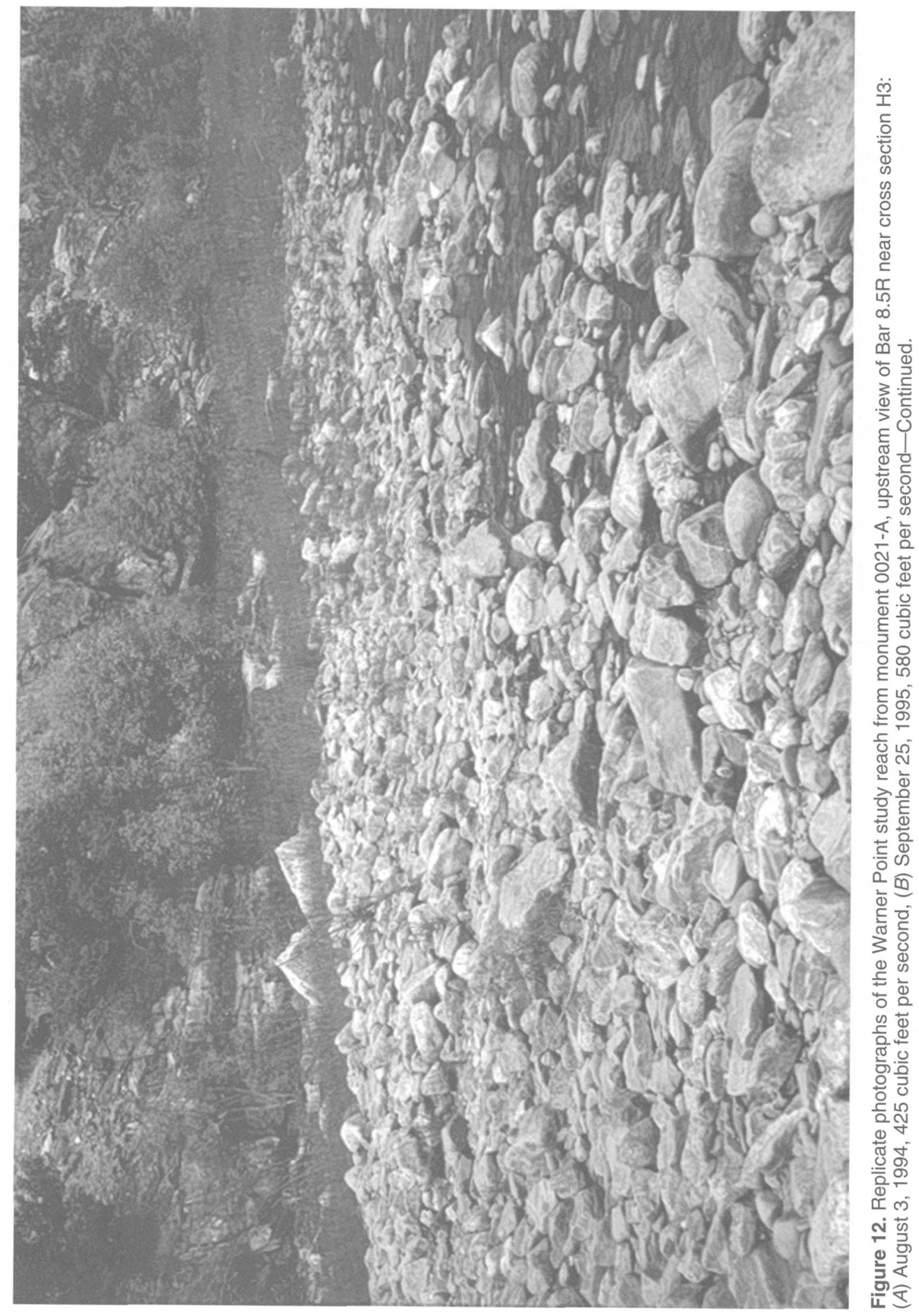

$\infty$ 


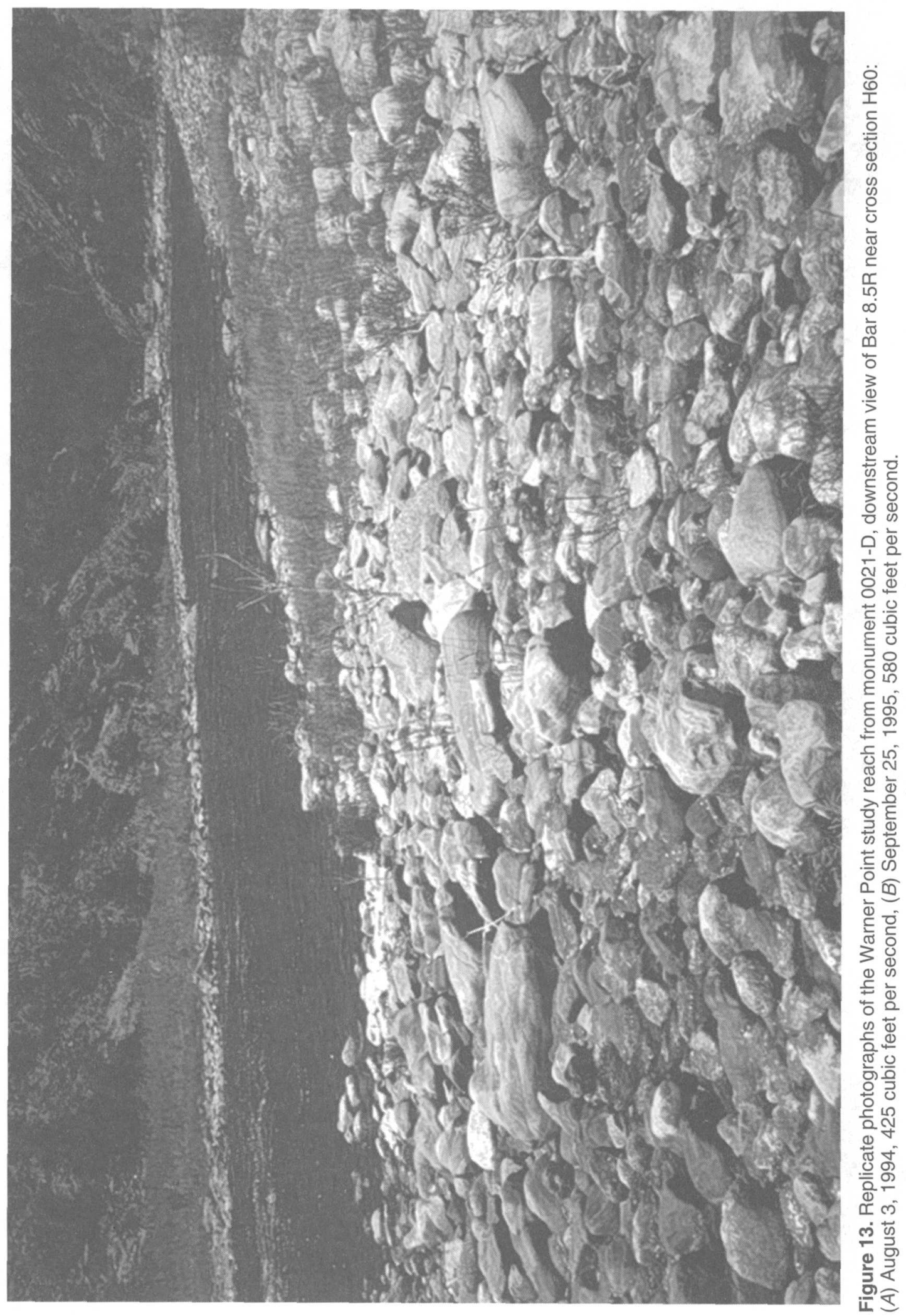

$\varangle$ 


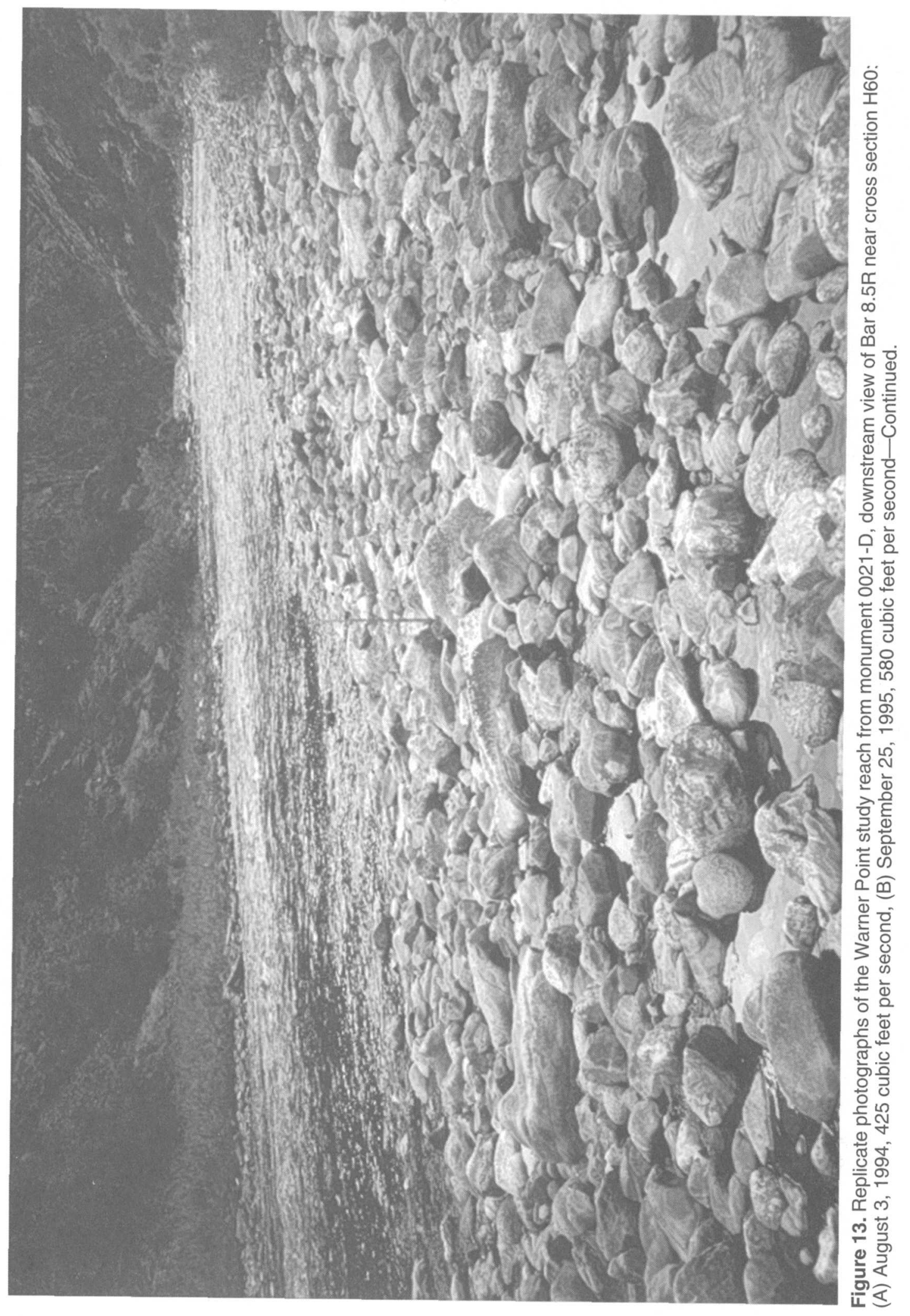

$m$ 


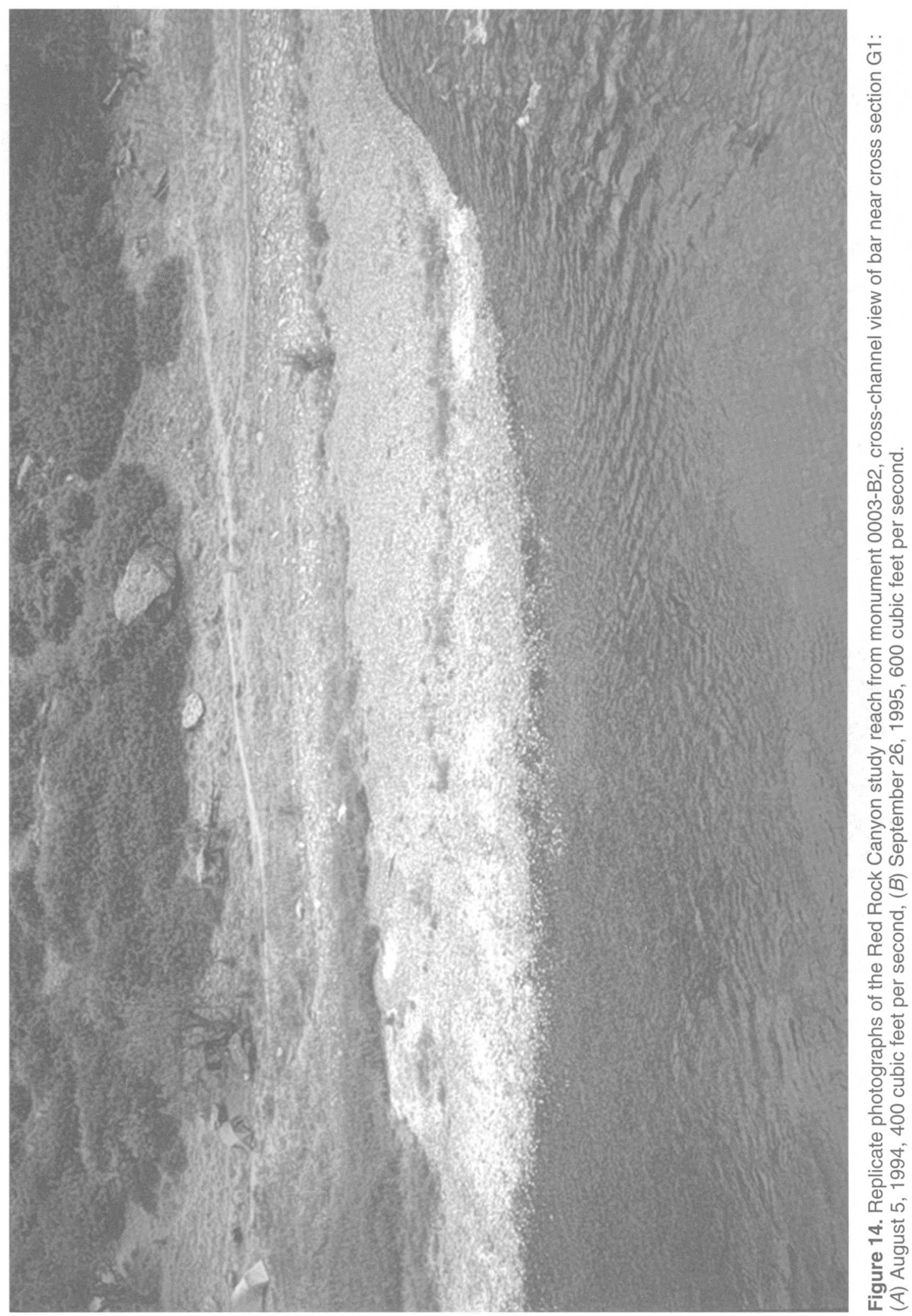

$\varangle$ 


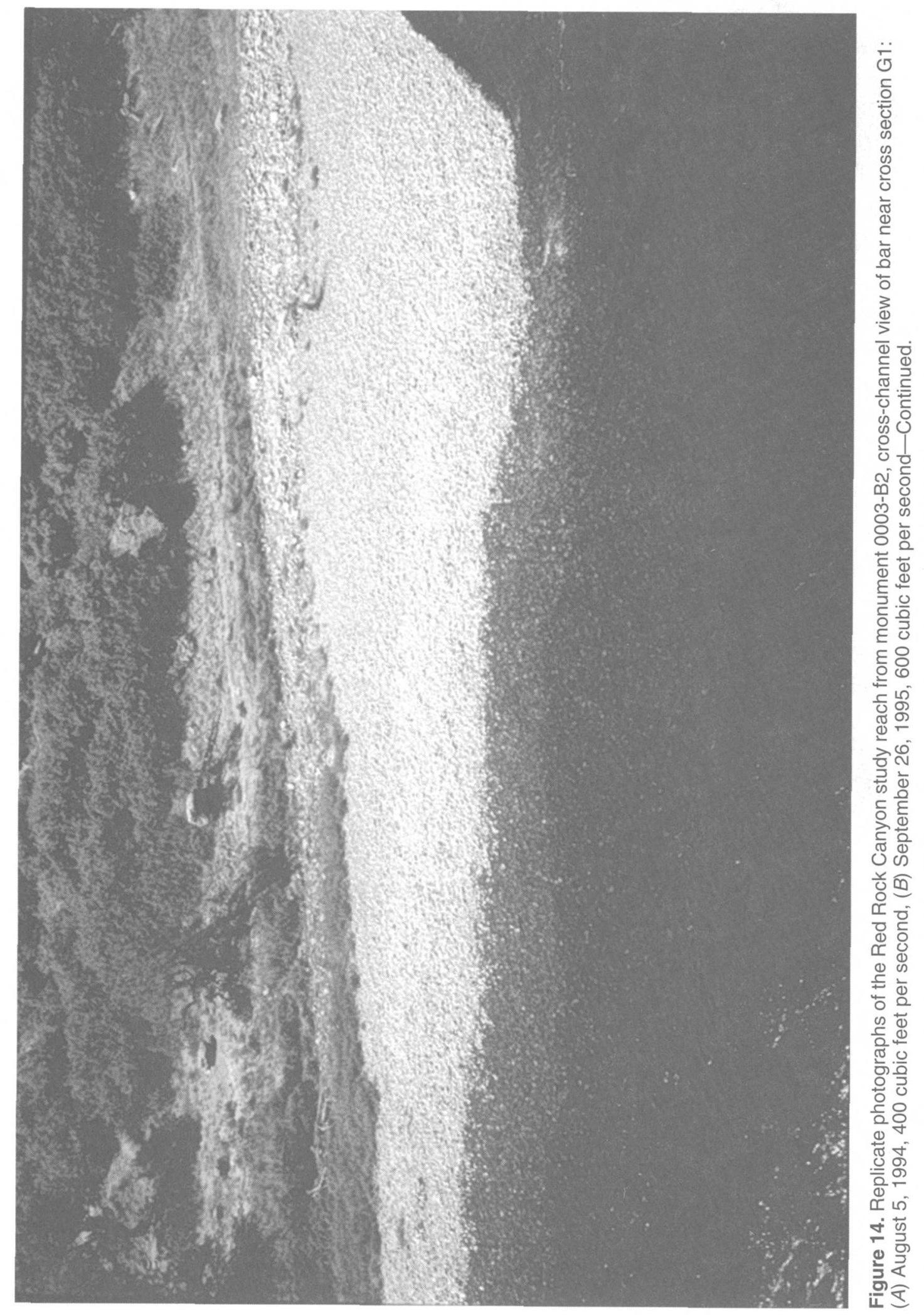

$\infty$ 


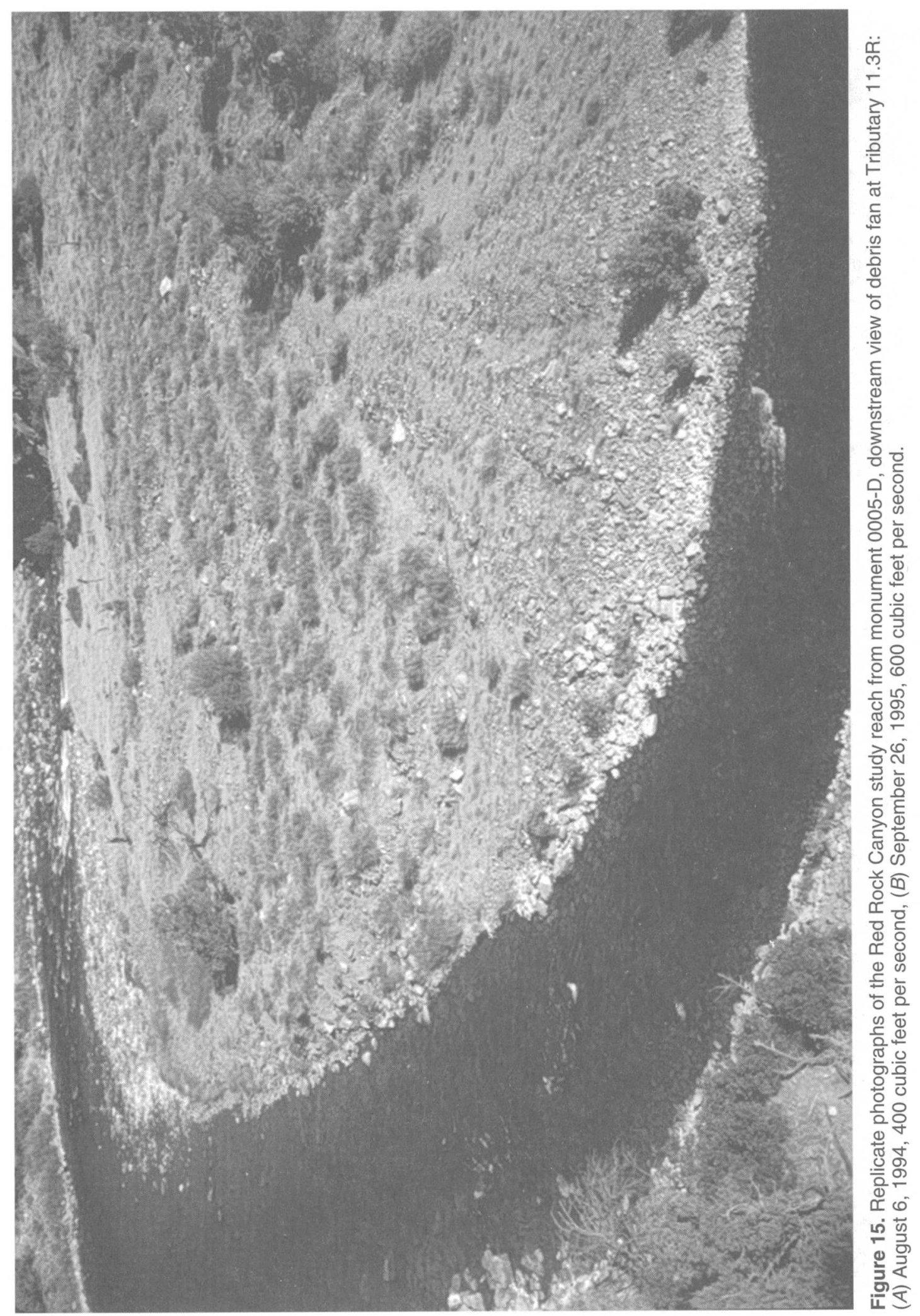

$\varangle$

Geomorphic and Sedimentologic Characteristics of Alluvial Reaches in the Black Canyon of the Gunnison National Monument, Colorado 


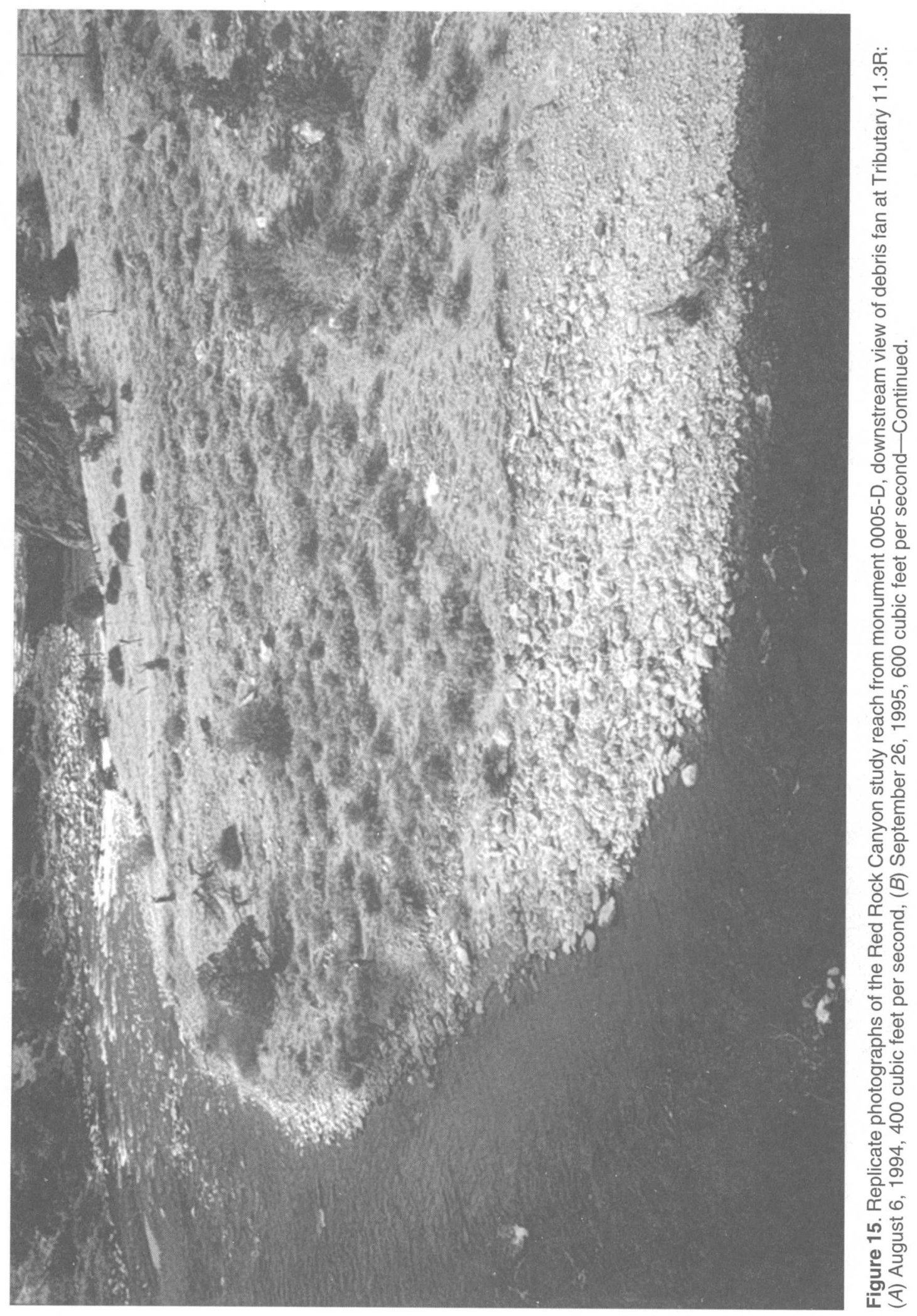




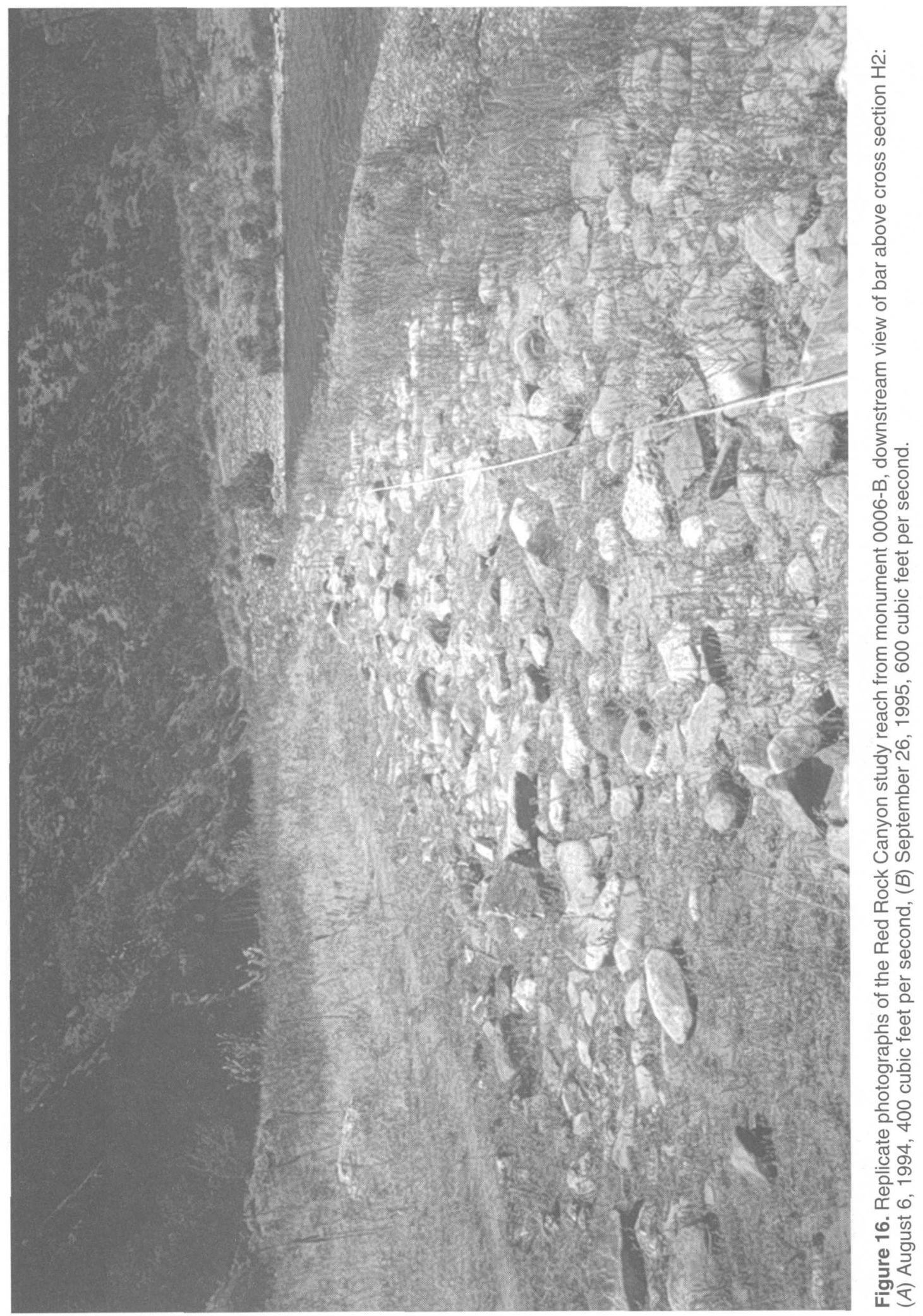

$\varangle$ 


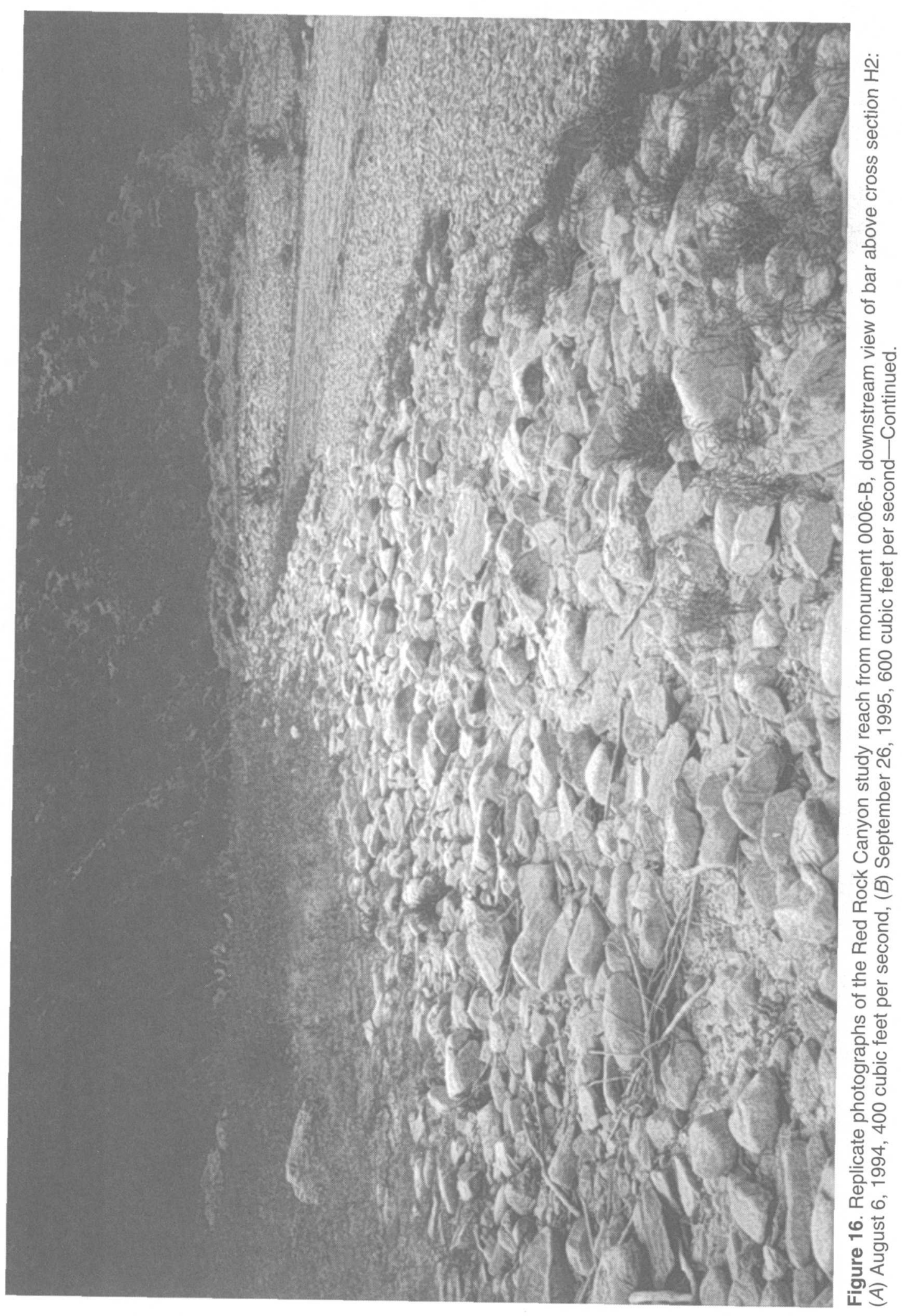

$\infty$ 


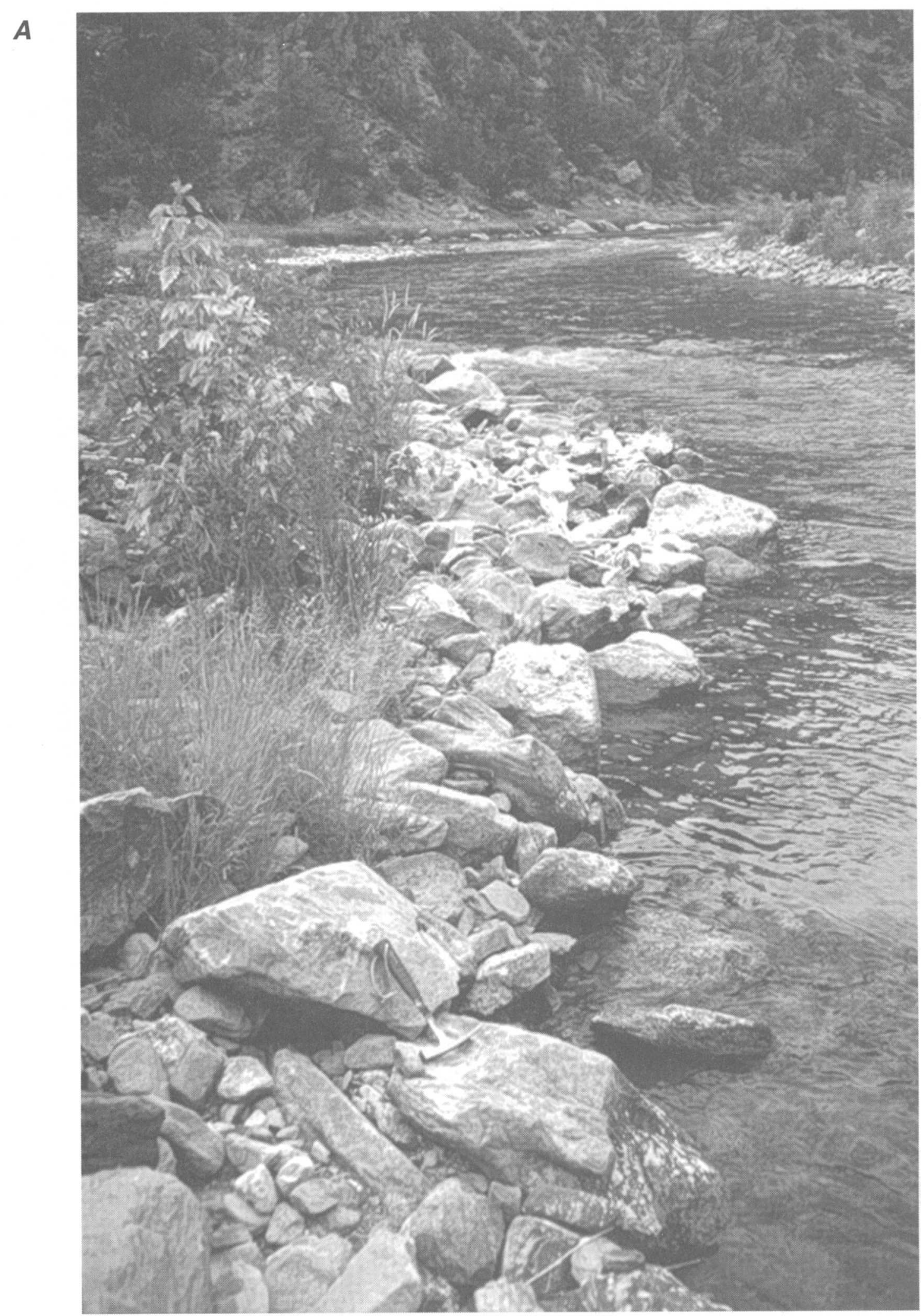

Figure 17. Replicate photographs of the Red Rock Canyon study reach from monument 0010-U, upstream view of debris-fan distal margin near cross section $\mathrm{H} 1$ : $(A)$ August 8, 1994, 410 cubic feet per second, $(B)$ September 26, 1995, 600 cubic feet per second. 
$B$

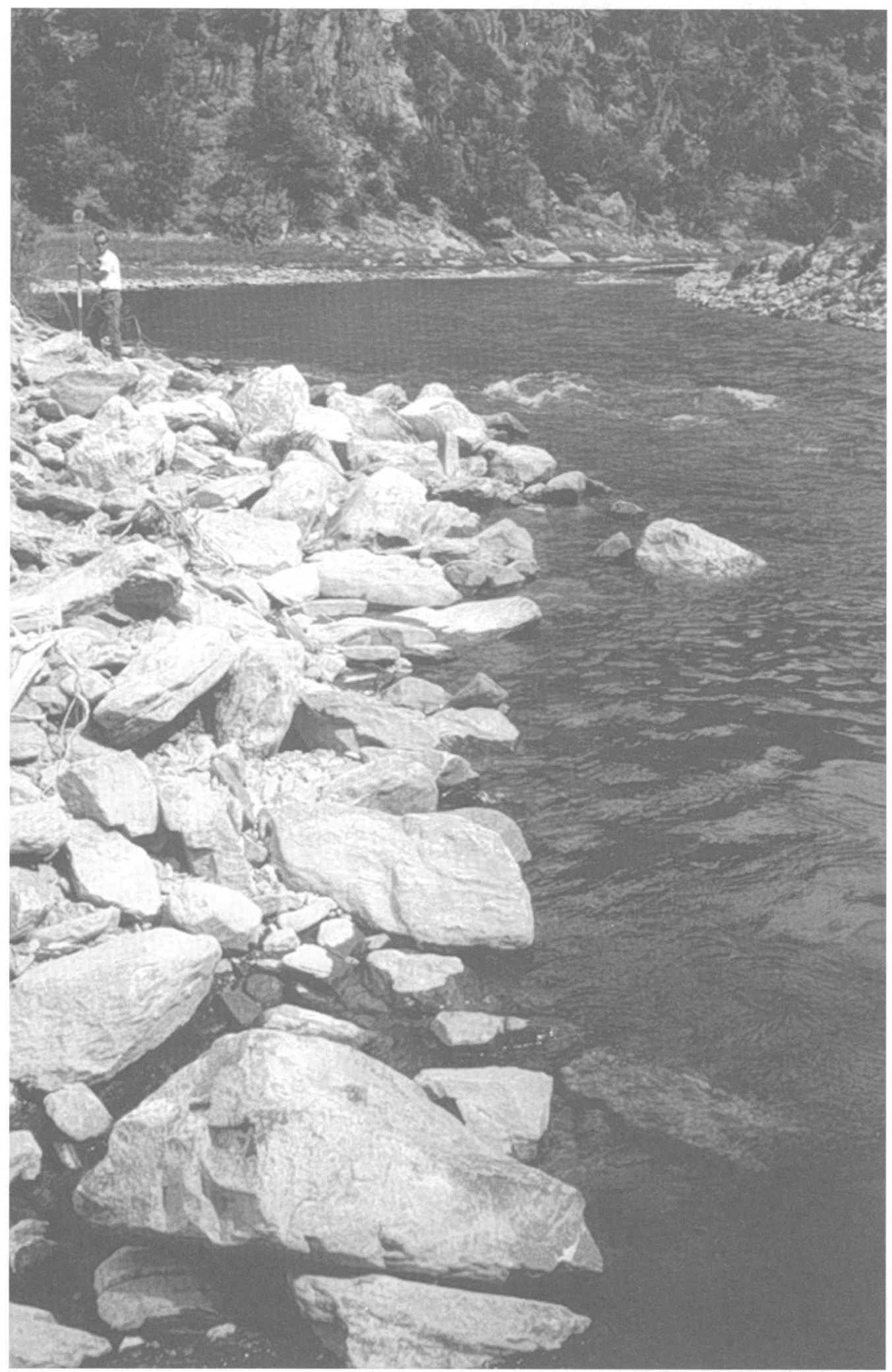

Figure 17. Replicate photographs of the Red Rock Canyon study reach from monument 0010-U, upstream view of debris-fan distal margin near cross section H1: (A) August 8, 1994, 410 cubic feet per second, (B) September 26, 1995, 600 cubic feet per second-Continued. 


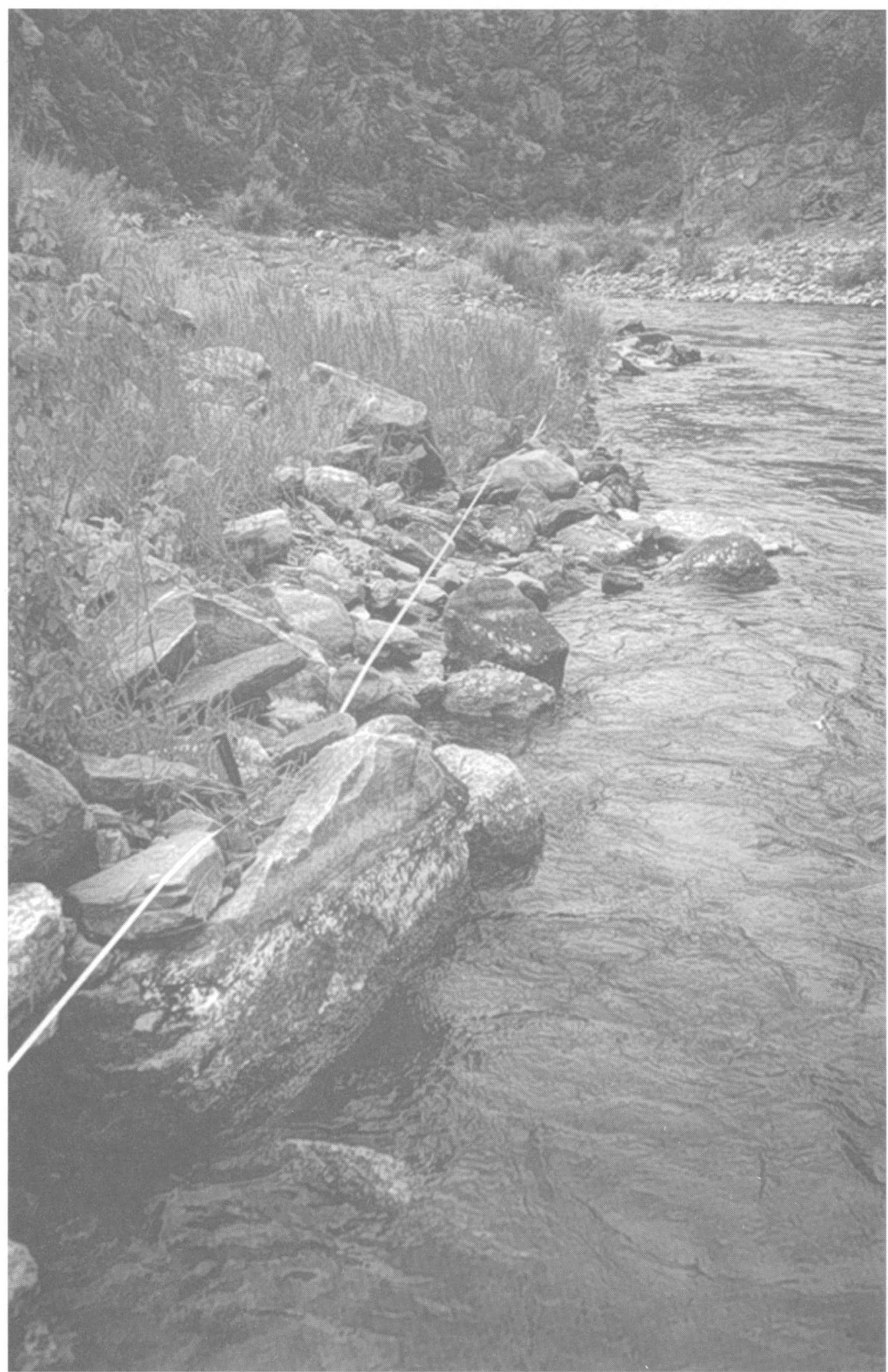

Figure 18. Replicate photographs of the Red Rock Canyon study reach from monument 0011-U, upstream view of debris-fan distal margin near cross section F1: $(A)$ August 8, 1994, 410 cubic feet per second, $(B)$ September 26, 1995, 600 cubic feet per second. 


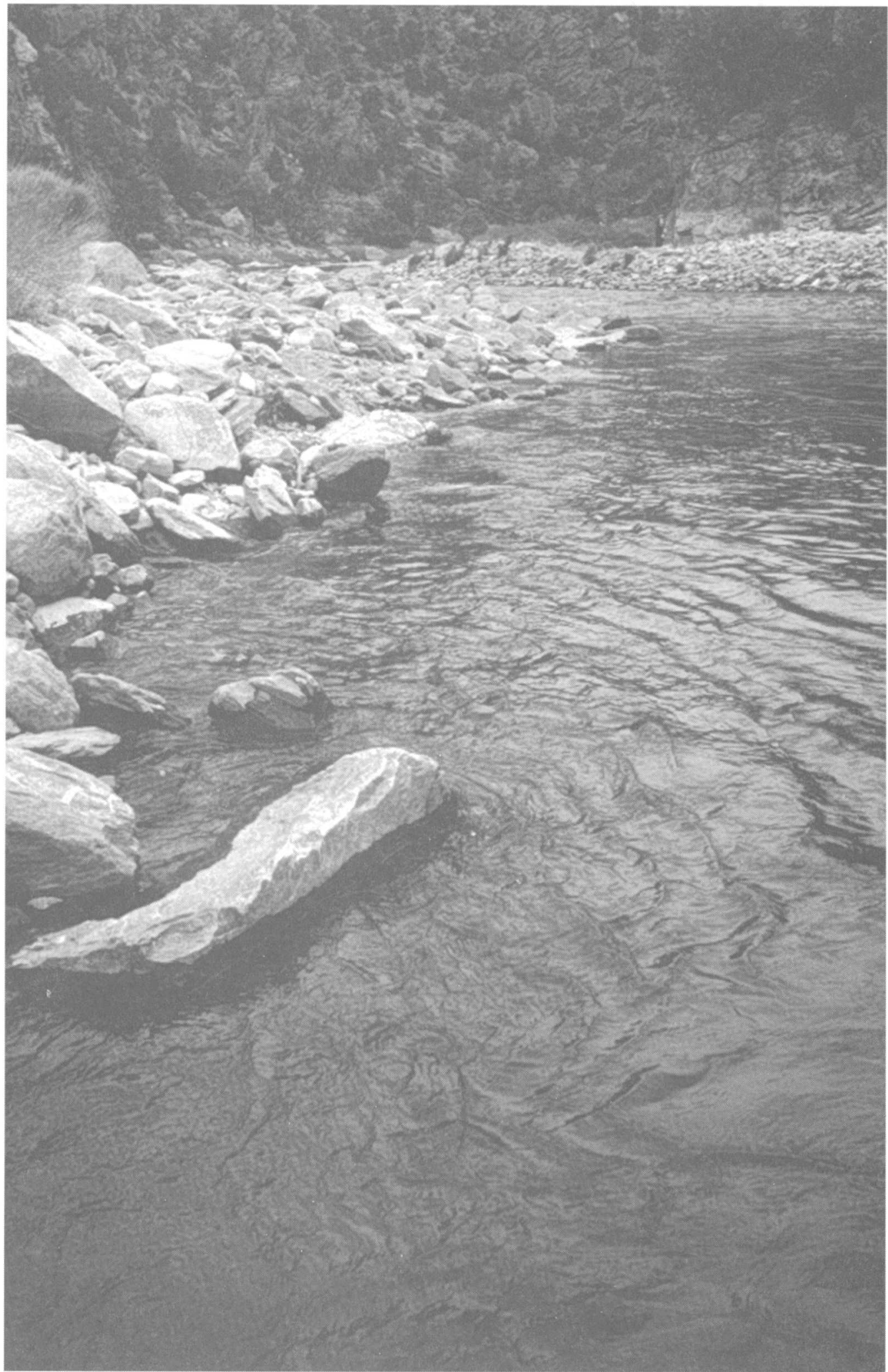

Figure 18. Replicate photographs of the Red Rock Canyon study reach from monument 0011-U, upstream view of debris-fan distal margin near cross section F1: $(A)$ August $8,1994,410$ cubic feet per second, (B) September 26, 1995, 600 cubic feet per second-Continued. 
